\title{
Women's Agency and Educational Policy: The Experiences of the Women of Kilome-Kenya
}

\author{
by \\ mutindi mumbua kiluva-ndunda \\ B.Ed.(Science), University of Nairobi, 1983 \\ M.Ed., Queens University, 1990 \\ A THESIS SUBMITTED IN PARTIAL FULFILLMENT OF \\ THE REQUIREMENTS FOR THE DEGREE OF \\ DOCTOR OF PHILOSOPHY \\ in \\ THE FACULTY OF GRADUATE STUDIES \\ (Department of Educational Studies) \\ We accept this thesis as conforming \\ to the required standard
}

THE UNIVERSITY OF BRITISH COLUMBIA

August 1995

(C) mutindi mumbua kiluva-ndunda, 1995 
In presenting this thesis in partial fulfilment of the requirements for an advanced degree at the University of British Columbia, I agree that the Library shall make it freely available for reference and study. I further agree that permission for extensive copying of this thesis for scholarly purposes may be granted by the head of my department or by his or her representatives. It is understood that copying or publication of this thesis for financial gain shall not be allowed without my written permission.

\section{(Signature)}

Department of EDUCATIONAL STUDIES

The University of British Columbia Vancouver, Canada

Date SEPTEMBER 12, 1995 


\begin{abstract}
This study examines women's experiences of formal education in Kenya. The study aims at making visible the cultural, historical, economic and political factors that shaped, and continue to shape, women's educational and employment opportunities. It also highlights women's agency exemplified in their struggle to provide their children, and particularly their daughters, with educational opportunities. The study draws attention to the gender and power issues that limit women's participation in the public sphere. These are issues that policy makers, politicians, and development agents have not and still do not adequately address.

The study employs post-positivist research methodologies, particularly feminist methodologies informed by post-colonial critiques. The women in this study are treated as social agents not as victims of men, and of economic and political trends. The women formulate strategies aimed at influencing or shaping the social system in which they are a part. The women's agency resides in their individual and communal endeavours and is constantly reinvented in the context of political and social change.

This research is an analysis of the experiences of 38 women born, raised and partly schooled in Kilome division, Makueni district. It focuses on the educational experiences of rural women living in two villages and a small town in Kilome division, Kenya. I use the women's discourse to critique the public discourse on education articulated in policy documents produced in the last 30 years since independence in 1963.
\end{abstract}

This study illustrates how women in Kenya have been largely absent at the national level where educational policies are formulated. Policy making has remained male 
dominated. Policy makers, charged with structuring and restructuring education to meet the country's development needs, continue to limit women's agency to the private sphere. The formulation of policies from the male perspective has intensified the public and private dichotomy. Absent in the public discourse on education has been the discussion of how gender, a social construction, has influenced opportunities available to men and women in colonial and post-colonial Kenya. Colonial gender constructions of femininity have continued to limit educational opportunities made available to women in post-colonial Kenya.

The Kenyan women in this study are cognizant of how these gendered assumptions shaped, and continue to shape, women's educational and employment opportunities. They re-negotiate and resist these gendered assumptions and they have become intervention agents for their children's education. The women's agency, however, is limited by their lack of economic power. The interplay between gendered cultural assumptions about femininity and the increased costs of schooling imposed by policy makers continue to have a negative impact on women's education. 


\section{TABLE OF CONTENTS}

$\begin{array}{ll}\text { Abstract } & \text { ii }\end{array}$

Table of Contents iv

List of Tables vi

List of Maps $\quad$ vi

Acknowledgements vii

$\begin{array}{lll}\text { Chapter One } & \text { Introduction } & 1\end{array}$

Background $\quad 3$

Rationale 4

Overview of the Study 6

Chapter Two $\quad$ Women in Kenya 8

Women and Education in Kenya 10

Women's Economic Activities $\quad 18$

Women and The Family 26

Women's Self-Help groups $\quad 32$

$\begin{array}{lll}\text { Chapter Three } & \text { Methodology } & 38\end{array}$

Theoretical Framework $\quad 39$

Research Design $\quad 48$

Reflexivity $\quad 50$

The Research Sites $\quad 53$

Kithumba village $\quad 55$

Life in Kithumba Village $\quad 55$

Schooling in Kithumba $\quad 57$

Kithumba Women's Self-help Group $\quad 58$

Kyandue Village $\quad 60$

Life in Kyandue Village 61

Schooling in Kyandue $\quad 62$

Kyandue Women's Self-help Group 63

Salama Town 64

Life in Salama 66

Schooling in Salama 67

Salama Women's Self-help Group 67

$\begin{array}{ll}\text { Participants } & 69\end{array}$

$\begin{array}{ll}\text { Interviewing } & 73\end{array}$

Interview/Discussion Topics $\quad 74$ 
Chapter Four

Chapter Five

Chapter Six

Chapter Seven
Translation of Interviews

Analysis of Education and Development

Policy Documents

84

Ominde Report (1964) 90

Sessional Paper \# 10 :African Socialism (1965) 93

1974-78 Development Plan 96

Gachathi Report (1976) 98

Mackay Report (1981) 103

Wanjigi Report (1982/83) 105

Kamunge Report (1988) 108

1989-93 Development Plan 110

Ndegwa Report (1991) 112

Kilome Women's Educational Experiences 123

Colonial Background 124

Women's Own Experiences of Education $\quad 126$

Educational Experiences of women's daughters 136

Factors Limiting Girls' Educational Opportunities 143

High Cost of Education $\quad 144$

Traditional Preference to Educate Boys 147

Assumption That Girls Will Get Married 149

Girls' Potential Motherhood 153

Responsibility for Sex education $\quad 156$

Poverty 158

Intensification Of Women's Labour To Educate

Their Children And Its Implications 163

Importance Women Attach to Educating Daughters 163

Support for Mothers 164

Support Own Families $\quad 167$

Making Marriage Choices 168

Women's Inability to Depend on Husbands for

Daughters' Education 175

Intensification of Women's Labour 177

Employment $\quad 179$

Sale of Property and Farm Produce 182

Petty Business 185

Limitations on Women's Efforts to Educate their Daughters 187

Women's Health 189

Girls' Education $\quad 191$ 


\section{Chapter Eight}

Chapter Nine

References

LIST OF TABLES

Table 1. Participants: A Summary

Table 2. Policy Reports Summary

Conclusions And Implications For Policy

Research Problem

Public And Private Discourses On Education

Implications for Policy

Support For Girls' Education Starting

At The Village Level

Re-entry of Adolescent Mothers into the

School System

Introducing Sex Education in Schools and

Communities

Support for Women as Intervention Agents for their Daughters' Education

Significance of the Study

195

198

202

205

207

209

214

214

215

227

231

232

234

235

237

239

72

122

LIST OF MAPS

Map 1: Research Sites

82 


\section{Acknowledgements}

I want to thank God for giving me the courage, strength and perseverance to complete this dissertation. This work would not have come to completion without the guidance, encouragement, material and psychological support of my research supervisory committee, friends, family and colleagues. I am indebted to you all.

I would like to express my sincere thanks to all members of my committee Drs. Jane Gaskell, Jean Barman, Deirdre Kelly and Leslie Roman for giving me guidance and support to bring this work to completion. To Jane Gaskell, I want to say a big thank you for being my supervisor. I appreciate your guidance throughout my $\mathrm{Ph}$.D. programme and for your support and encouragement particularly at times when I felt truly discouraged. It was a pleasure working with you.

I am thankful to Jean Barman for agreeing to participate as a member of my research committee at the eleventh hour. Thank you for all the time you spent to meet and discuss with me my work and to read all those drafts! Thank you for your genuine interest in my work and for your support to the end. To Leslie Roman, I want to thank you for being my teacher and for teaching me that researchers do not have to be "flies on the wall" and that my work does do not have to be just another "discourse of horror". Deirdre Kelly, thank you so much for all the time you took to find me relevant materials on my topic. I am grateful for the support you gave me when my father passed away. I also would like to thank Dr. Kivutha Kibwana of Nairobi University for his support during my fieldwork in Kenya. 
Special thanks go to Dr. Kogila Adam-Moodley who in her own way supported me and my family during our stay in Canada. Dr. Peter Seixas, I appreciate your kindness to me. Dr. Tony Clarke, I am grateful for the time you took to help me prepare for my orals. Your desire to support students is unmatched.

I extend my gratitude and thanks to the Kilome women whose enthusiasm and generous participation made this study possible. I thank you for welcoming me into your lives and sharing with me your experiences. I hope that this is just the beginning of our work together.

I also would like to acknowledge and thank the International Development Research Centre for the research funding that made it possible for me undertake my fieldwork in Kenya. Without this support, this work would not have been possible. Special thanks to Rita Bowry, Constance Lim and Estelle of the IDRC.

There were many friends who worked so hard to make me cope with the pressure of being a mother, a black woman and a student here in Canada. These include Pat O'Riley, Bev Lock and Renee Fountain (my white sisters). I want you to know that your love and support of me made me deal with the worst of crises. I cannot thank you enough but to hope that we will remain friends. To Jennifer Khamasi, I am grateful for your support and encouragement. I appreciate the time you spent with me listening, talking and discussing issues. I also would like to thank the following friends Janice, David, Faith Maina, Shibairo, Kithome, George, Rosa, Garry, Akosua, Yvonne Brown, Shauna, Tom, Darlane and Doris Mutta for their support. I want to thank Verna Fountain for being my mother so far away from home. 
Finally, my special appreciation to my family. To my husband, Thomas, you have been a great support and critic of my work. You have helped so much in shaping this work. I thank you for enduring so much so that I could complete this work. You took care of the children so that I could spent time on this work. Thank you very much. To my children, Ndambuki and Nthenya, I want to thank for "praying without ceasing" for this project to end. I wonder why but your prayers were surely heard and answered. I know you missed me a lot but I hope that your sacrifices are not in vain.

To my dear brothers, sister and sisters-in-laws, Fred, Nzioka, Jimmy, Gerald, Gregory, Mumo, Faith, Nzilani, Regina and Rosemary I appreciate all your encouragement, material and psychological support throughout all these years. Fred, I am most indebted to you. Your intervention has made this work possible. Mumo, thank you so much for your love and kindness. To my mother, Hannah Ndoti, thank you so much for teaching me the importance of endurance. I thank you for your wisdom.

I dedicate this thesis to the women of Kilome who struggle to offer their children educational opportunities and to my deceased father, Jonah Kiluva who had a passion for education. His spirit rejoices. 


\section{Chapter One}

\section{Introduction}

This is a study of women's perceptions of the uses of education in Kenya. The study focuses on rural women's experiences of formal education in Kilome division, Makueni District, Kenya. The study aims at making visible the cultural, historical, social, economic and political factors that have shaped and continue to shape women's educational and employment opportunities. It highlights women's agency in their struggle to offer their children, and particularly their daughters, with educational and economic opportunities.

In this study, the women narrate their stories in relation to education, highlighting their experiences of formal education and the constraints that they have faced and continue to face in Kenya today. The study is directed at exposing and drawing attention to the gender and power issues that limit women's participation in education and in the formal employment sector and that exacerbate gender inequalities and the subordination of women. These are issues that policy makers, politicians, development agents, and educators do not adequately address or challenge. This study examines these issues from the standpoints of women.

The discussions with the women are centred around (a) education, (b) paid and unpaid work, (c) family and sexuality and, (d) women's self-help groups. The women articulate their experiences relating to education in the past (their own) and in the present (their daughters), highlighting fears and hopes, possibilities and constraints that structure their daily lives. They also articulate their experiences concerning labour, paid and unpaid. 
This makes visible the increasing demand for women's labour as they intervene for their families' welfare within a harsh social, economic and political climate. The discussion of family and sexuality shows women's perceptions of themselves, their daughters and their roles in the family. The women do not define their agency simply around motherhood in the private sphere. As Stamp (1995) argues, most women in African communities have multiple subjectivity as mothers, daughters, sisters, traders and farmers. She argues that the women's multiple subjectivity is the bedrock of their agency in the Kenyan state today. Women's participation in self-help groups further highlights women's collective agency. I construe the women's narratives as their private discourse on education, one that operates in the family and in the community.

I contrast the private discourse with the public discourse on education articulated in policy documents, highlighting the contradictions and similarities between the different narrative standpoints. The public discourse regarding the purpose of education of men and women in Kenya is set out by male politicians, policy makers and international development agencies such as the World Bank. I analyze the following documents produced over the last 30 year period to document the public discourse: Ominde Report of 1964, the first non-racial educational report in Kenya, Sessional Paper Number 10, derived from the Kanu Manifesto (1965), Gachathi Report (1976), MacKay Report (1981), Wanjigi Report (1982), Kamunge Report (1988) and Ndegwa Report (1991). I also analyze national Development Plans (1974-78; 1989-1993) because education is seen as an instrument of national development. The analysis of the private and public discourse 
on education makes visible women's agency and the systemic limitations women face in accessing educational and economic opportunities in Kenya.

\section{Background}

Education occupies a central position in the national development plans of many countries, including Kenya. Since independence in 1963, the government has set up several commissions and working parties to look into ways and means of structuring and restructuring education to meet the country's development needs. These commissions and working parties have recommended policies that have served to shape education and educational opportunities in Kenya. While women constitute over $50 \%$ of the population of Kenya, gender issues that limit their participation in education and in the economy have consistently remained invisible to policy makers. This has maintained the low representation of women in all levels of education and in the labour market since educational qualifications are used as criteria for hiring for employment in most areas in the modern sector. The commissions that have been set up have emphasized the economic rather than the social function of education.

While the public discourse on education has expressed a commitment to providing education to all Kenyans, absent in this policy discourse has been the discussion of how gender has influenced opportunities available to men and women in colonial and postcolonial Kenya. Gender is a social, cultural, economic and political construction of what it means to be a girl or a boy, a woman or a man. It is a social process that ascribes characteristics and behaviours to women and men according to their biological sex (Eyre, 
1993). Gender constructions of femininity have continued to limit educational opportunities made available to women in post-colonial Kenya.

\section{Rationale}

In Kenya, men play a dominant role in all aspects of governance. Policy making, planning and development and implementation of policies and programmes in Kenya usually take the male perspective (Kibwana, 1992). The failure to address the impact of seemingly gender-neutral educational policies has reinforced gender inequities in educational opportunities. For instance, the implementation of the cost sharing strategy, where parents have to pay for schooling, has increased women's workloads and intensified girls' struggle for educational opportunities. The interplay between gendered cultural assumptions about femininity and the increased costs of schooling have a negative impact on women's education.

The formulation of policies from the male perspective also intensifies the public and private dichotomy on the basis of gender. Policy makers seem to confine the discourse on women's education to their agency in the private sphere. They do not view women as economic and political agents in the public sphere alongside men. This has led to the formulation of policies that have served to reinforce gender inequities in the public sphere. This thesis proceeds on the assumption that gender and power issues must be taken as fundamental categories within which human social relations are organized (Harding, 1986).

The government of Kenya professes to be committed to the provision of equal opportunities to all Kenyans irrespective of sex, race and religion. The government also 
claims to be committed to addressing the unequal social, economic, and political status of women in Kenya. However, in reality, the government is resistant to gender issues. Women, such as professor Wangari Mathai, who have voiced and articulated women's concerns, have frequently been met with severe and brutal repression. Mathai, the first female professor of veterinary medicine in Kenya, and founder of the world renowned environmental GreenBelt movement, has consistently been arrested for challenging men's supremacy in making decisions that are gender biased and environmentally destructive. Women who attempt to exercise their political and economic agency in the public sphere are faced with a multitude of limitations. As Mathai (1991) observes, gender, marriage and ethnicity (among others) serve to limit women's agency contrary to the popular publicly promoted rhetoric that "the sky is the limit."

My experiences as a female child growing up in a rural area also inform this study on gender and power issues nestled in cultural beliefs about women that limit women's/girls' educational opportunities in the society. The clear gender division of roles in my family were those of a mother, wife, care giver, and food producer. These were roles that were limited to the private sphere and were not seen to require formal education. Women had performed these roles in the pre-colonial era before the introduction of formal education and continued to learn them informally. On the other hand, the man was the head of the household, though often he spent most of the time in the city as a migrant worker. He was the "breadwinner," the income earner, and one who made all the decisions that shaped each and every household member's life. Formal education was seen as necessary for his economic role. The woman's unpaid labour, 
though crucial to the survival of the family, was not as valued as the paid work performed by the man.

About $50 \%$ of the girls who enrolled in the first year of primary level education (Standard 1) with me left school before completing this level to become mothers and/or wives or to work as domestic help. Less than $30 \%$ of the girls passed the secondary entry examinations and even fewer completed that level. Only three of us completed the tertiary level of education. I am, therefore, personally aware of how gender and power factors shape women's educational and economic opportunities within the historical, social, economic and political context of Kenyan society.

\section{Overview of the Study}

Through the literature review in chapter 2, I examine the ways gender has structured Kenyan women's participation in education, the economy and in the family. Chapter 3 deals with the methodology of my study. I first discuss the theoretical framework and then I describe the research sites. Next, I discuss the participants, research topics and translation of interviews. Finally, I reflect on doing research as both an insider and outsider in Kilome division. Chapter 4 analyzes the policy documents to show how policies have implications for the public sphere and how they limit women's agency. Chapters 5, 6, 7 and 8 present the interview data. Chapter 5 presents Kilome women's educational experiences. Chapter 6 deals with cultural gendered assumptions that limit girls' participation in education. Chapter 7 examines the intensification of women's labour as they struggle to educate their children. This includes an examination of rural women's economic activities within a gendered economy. Chapter 8 deals with women's agency in 
self-help groups and the potential as well as the limitations of these groups in addressing women's concerns. In chapter 9, I contrast the women's private discourse with the public discourse on education emphasizing the contradictions as well as the similarities between the narratives. Finally, I examine the implications of this study for policy and research. 


\section{Chapter Two}

\section{WOMEN IN KENYA}

Equality for women involves education but not just education. Equal access to basic education is endorsed as a basic human right in The World Declaration on Education For All, and adopted by the world community in Jomtien, Thailand in 1990. One of the central objectives of The Declaration is the reduction in the current gender gap in education, which James Grant as Executive director of UNICEF has described as "gender apartheid" (UNICEF, 1992). Experts disagree, however, on how best to achieve gender equity. Roberston (1986) argues that basic education enhances subordination of women because it does not offer women meaningful economic opportunities. Hughes \& Mwiria (1989) argue for girls' higher education which they claim has a greater potential for enhancing equity for Kenyan women in the labour market. Specifically, they note that equity for Kenyan women is elusive if factors that limit women's access to scientific and technical skills and exclude them from important areas of the labour market are not addressed. In the same vein Mbilinyi (1972) argues that:

The only way that African women will ever be able to advance beyond their present state of social, political, [economic] and legal inferiority is by getting wage-earning jobs. ... But without the necessary technical skills and vocational training women will remain unemployed or have access only to the lowest-level jobs. (p. 63)

Gender discrimination, in addition to education, limits women's opportunities in the formal employment sector. Assumptions about appropriate roles and suitable careers for women are used to deny them opportunities. Women in Kenya, like many of their 
counterparts elsewhere in the world, do not receive remuneration equivalent to that of men with comparable educational attainment (Kagia, 1985; UNICEF/GOK, 1992). The few women who participate in the formal employment sector are concentrated in traditional female occupations characterised by low remuneration, few or no benefits and little opportunity for advancement. In the 1990s, women are experiencing more difficulties than men in securing work in the formal employment sector (International Labour Organization (ILO), 1991). Gendered assumptions shape women's lives in ways that limit their participation in public institutions (education, economy and politics) in Kenya. Gender is central to the way in which power, property, prestige, educational and employment opportunities are organized, regulated and distributed. However, women are not a coherent group, rather, women are constituted as women through the complex interaction between class, culture, religion and other ideological institutions and frameworks. "They are not 'women' a coherent group--solely on the basis of a particular economic system or policy” (Mohanty, 1991, pp. 63-64).

This chapter is a review of literature that explores the nature of women's struggle for equal opportunities in Kenya within the framework of "gender stratification in which power, property, prestige and social recognition are organized, regulated, distributed and given meanings" (Alberg-Maina, 1991, p. 35). The literature explores the factors which sets limits on women's agency both in the private and public sphere. This is important because rural women struggle to provide their daughters educational opportunities to participate as economic and political agents in the public sphere. 
In the first section I examine women's educational opportunities in Kenya focusing on possibilities and constraints that women face. The second section is on women and the economy. Thirdly, I discuss women and the family, and the final section is on women's self-help groups followed by a set of conclusions.

\section{Women and Education in Kenya}

Jennifer Riria-Ouko is one of the most outspoken proponents of women's education in Kenya. Her analysis of education, its functions, structure and output in relation to women, demonstrates that women have been "forgotten, neglected and discriminated against in the provision of educational opportunities" $(1984$, p.7).

Gender inequities in provision of educational opportunities in Kenya have historical and cultural bases (Mukui, 1985). Formal education was introduced to Kenya by the Christian missionaries in the middle of the 19th century (Kurian, 1987). Later, education was developed by the colonial government along gender and racial lines. Colonial education severely restricted the education of Africans and almost totally ignored the education of girls (Kagia, 1985). Colonialists, missionaries, and indigenous people all used gender as a criterion for deciding who would receive formal education. Between 1950-1954, only 1197 girls as compared to 7419 boys passed the secondary level entrance examinations and only 157 girls compared to 2875 boys sat for the Cambridge School Certificate Examinations--grade 12 equivalent (Kagia, 1985). Women were systematically excluded from participation in education and thereby from the modern employment sector as formal education credentials and gender became vital criteria. 
Since independence in 1963, Kenya has made significant progress in providing educational services to all Kenyans. The combined efforts of parents, local communities, government and non-governmental organizations have resulted in high participation in basic education. The national enrolment ${ }^{1}$ rate at the primary level in 1991 was $95 \%$ compared to $50 \%$ at independence and the enrolment rates of boys and girls in primary school are steadily approaching parity. Kenya follows the 8-4-4 (8 years of primary, 4 years of secondary and 4 years of university education) system of education. Primary education is from Standard 1 (6 years old) to Standard 8 (ages 14 and above). Most primary schools are coeducational while most secondary schools continue to be divided by gender. In 1991 girls constituted $48.7 \%$ of the total enrolment in primary schools, a gender ratio that has remained constant since 1989. Nevertheless, few girls are completing this level of education. A large number of girls who enrol in Standard 1 drop out of school before they reach Standard 8. For example, of the 864,593 pupils who enrolled in Standard One in 1984, $58.4 \%$ of the girls and $53.6 \%$ of the boys left school before completing Standard Eight in 1991 (UNICEF/GOK: Women and Children, Situation Analysis, 1992; Economic Survey, 1992). Though the statistical difference between the drop out rates among boys and girls are not great, the factors that lead to the high drop out rates among the girls and the fate of those girls who drop out are significant. National enrolment rates conceal serious gender, regional and socio-economic disparities in enrolment, participation and achievement (UNICEF/GOK, 1992).

\footnotetext{
${ }^{1}$ National enrolment rate is the percentage of enrolment of all school age children.
} 
The high drop out rates among girls in the primary level of education are associated with (a) high pregnancy rates among girls in senior primary levels, (b) high tuition and non-tuition fees, (c) cultural and traditional practices such as child bride and nomadic practices, and d) poverty resulting in child labour. Primary school girls are among the increasing number of adolescent mothers in Kenya. In 1986, 12 girls per 1,000 who were enrolled in the secondary level of education left school due to pregnancy (UNICEF/GOK, 1992). Riria-Ouko (1984) points out that despite the fact that many girls are leaving school early because of pregnancies and lack of school fees,

The educational system seems to blame the girls in this respect instead of helping them to go through the system as well as the boys. Lack of the system to sympathize with the girls' plight in this respect translates into lack of proper and adequate schools for girls, victimization as a result of pregnancy and construction of expensive boarding schools (that the girls will never enter). (p. 8)

Girls who get pregnant are blamed and are forced to withdraw from the formal education system. Pregnancy marks the end of formal school for most of these girls.

The increasing cost of education exacerbated by the implementation of the costsharing strategy by the government of Kenya has become another major barrier to girls' educational opportunities. The burden of tuition and non-tuition fees has been too heavy on most parents in rural areas, forcing them to make choices about who is to be educated and for how long. Often, the choice has been to invest in the education of boys for cultural and economic reasons. Therefore,

Cost-sharing, unless implemented with great sensitivity to gender concerns, is likely to disadvantage women and girls at all levels. When poor parents are forced to choose between investing in a male child or a female child, the majority will choose their sons. (UNICEF/GOK, 1992, p. 108) 
Poverty as well as gendered cultural beliefs about the role of girls and women in the society also limit girls' educational opportunities. The widespread rural-urban male migration and changing social relations in Kenya have resulted in women becoming de facto heads of households and heads of households who must bear all or a large part of the burden of educating their children. Because female heads of households have limited access to resources such as land on which they could produce foodstuffs to provide for their families, girls from such households are likely to drop out of school. Cubbin (1991) argues that in Kenya, women's economic power increases girls' educational opportunities since "economic power is the strongest determinant of gender-based privilege in a society" (p. 1064).

Girls enjoy a much lower status than boys in the cultural, economic, political, religious and traditional context that prevails in much of Kenya. From an early age, boys and girls are taught skills and assigned duties in accordance with traditional genderspecific division of labour. Girls are likely to enrol in school late because of a need for child labour and they are likely to be overburdened with household chores which adversely affect their school performance. Girls who enrol late in school will reach adolescence and puberty at lower primary levels where there is a higher chance of performing poorly or dropping out of school due to pregnancy or marriage. Hyde (1993) notes that among subSaharan countries, Kenya included, factors responsible for the second-class status of women in education include:

Ideas about the appropriate roles for women in the labor market or in society, about the biological unsuitability of women for science, and about the genderbased division of work in the household and on the farm influence decisions about schooling as do income, class, religion, and rural or urban residence. (p. 108) 
Girls are more likely than boys to be withdrawn from school by their parents to help with household chores or to render services as maids (child labourers) to help feed their families. In addition, young girls are married off as child brides to elderly men for bridewealth, part of which is likely to finance the education of male siblings. Laws that prohibit the practice of child brides and child labour are not enforced just like many other laws that grant women equal opportunities and treatment in Kenya.

Few Third World countries have national policies in place to expand access to higher education opportunities for women (Biraimah, 1991) and Kenya is no exception. The education system is a sharp pyramid with girls' enrolments decreasing as they move up the educational ladder, resulting in fewer girls than boys in the secondary level and even fewer in the tertiary levels of education (Riria, 1984; Economic Survey, 1991; Rathgeber, 1991). Of the 400,000 Kenyan children who complete the primary cycle, only about $40 \%$ gain access to secondary schools. In 1990 , girls represented $43 \%$ of the 171,071 students enrolled in the first year of the secondary level of education (UNICEF, 1992; Republic of Kenya Statistical Abstracts, 1991; Women's Bureau/SIDA, 1993).

Modest progress has been made to increase the number of girls attending secondary level of education in Kenya. However, the limited number of government maintained secondary schools for girls, poor course selection, high drop out rates due to high tuition fees and high pregnancy rates and curriculum limit girls' education at the secondary level of education (Eshiwani 1985). The poor quality of the schools that girls attend negatively influence girls' educational experiences in terms of achievement, subject options and career choice. By 1990 there were 2,658 secondary schools in Kenya of which 
635 were government-maintained (public) and 1,755 were harambee (community sponsored) schools and 268 were private schools. National schools are well established academic government schools which are boarding and recruit Form 1 students on a national basis. Harambee schools are created and maintained through community self-help. The government posts a small number of trained graduate ${ }^{2}$ teachers to harambee schools. In Kenya girls primarily attend harambee schools that have poorer equipment, less-qualified teachers and more limited curricula than the government maintained schools that boys are likely to attend (King \& Hill, 1993). In 1979, girls represented only $33 \%$ of the students in government maintained schools. ${ }^{3}$ Several studies have shown that girls' performance in secondary level examination is better in government-maintained schools than in harambee and better in girls only schools (King \& Hill, 1993).

Government-maintained schools admit students who excel in the national secondary school entrance examinations. Girls, particularly those living in the rural areas, have fewer chances of excelling in their secondary school entry examinations. The ruralurban migration of males to the cities has left women and girls responsible for the domestic labour that sustains a household. The need for girls' labour affects their school attendance and allocation of study time which in turn affects their school achievement. The majority of the few rural girls who excel in their secondary entrance examinations and are admitted into government maintained schools end up in harambee schools because their parents cannot afford to pay tuition, boarding fees and related fees charged in government maintained schools. Pressed by lack of resources, most parents are able only

\footnotetext{
${ }^{2}$ Graduate teachers are those teachers who have a degree in education. ${ }^{3}$ These are the latest statistics available. Later reports do not show enrolment along gender lines in the different types of schools in Kenya.
} 
to pay the secondary school fees by installments. These arrangements seem only possible in harambee schools where the principal is a members of the same community and knows his/her students' parents.

Girls in the secondary level of education are conditioned to gender biased learning materials and classroom dynamics that affect their performance in national examinations at all levels of education (Hughes \& Mwiria, 1989; Obura, 1992; Osler, 1993). Girls' overall performance in the university entry examinations taken at the end of secondary level education is poor. This is particularly so in science and mathematics subjects and explains the low representation of girls in science and science related careers in tertiary institutions (Eshiwani, 1985). Studies show that girls' performance in science and mathematics subjects is influenced by the quality of schools that they attend, by sexism in schools, particularly in coeducational schools and by anticipated discrimination in the labour market. Riria-Ouko (1984) points out that most girls' schools are not as well equipped as boys' schools to teach science subjects at the secondary level. Girls' performance in science subjects and mathematics has been shown to be better in girls' only schools (Ndunda \& Munby, 1991; Rathgeber, 1991). Girls who do not perform well in science and mathematics subjects are eliminated from science and science related careers which are in demand and well remunerated.

Girls' construction of science futures is limited by traditional notions of femininity and anticipated discrimination in the labour market particularly if they pursue careers that are male-dominated. Girls tend to choose careers that will allow them eventually to prove their femininity by becoming wives and mothers. They choose careers where they feel 
they are less likely to be discriminated against in the labour market and which are compatible with their gender roles as mothers and/or wives (Ndunda \& Munby, 1991).

In 1990, for instance, most girls in the final year of secondary education were enrolled in home science (87\%) and typing with office practice (96.3\%) and very few girls chose pure science subjects and/or trades courses in this level. In the same year, girls represented $34 \%(11,783)$ of the total number of students enrolled in pure science subjects and their enrolment in wood work, metal work, building construction, power mechanics, electricity was minimal at $3 \%, 1 \%, 8.7 \%, 4.1 \%$ and $1.9 \%$ respectively (Republic of Kenya, Statistical Abstracts, 1991, p. 188).

Therefore, at the primary and secondary levels of education, girls are dropping out of school in considerable large numbers. At the secondary level they have continued to attend poorer quality schools in disproportionately high numbers and have restricted access to a broad range of curricula particularly in sciences. Fewer girls are reaching the tertiary level of education. Women in Kenya are encumbered by a plethora of barriers to educational opportunities.

Providing women with more education without changing the gender and power structures that reinforce and perpetuate gender inequities will not facilitate women's access to educational, employment level and political opportunities equal to those of their male counterparts. The stratification of the society along gender lines makes it possible to limit women's educational opportunities as well as to deny educated, capable women positions of power in a male-dominated socio-cultural system (Hughes \& Mwiria). 
Feldman (1983) argues that "women in Kenya suffer the impact of gender relations which place them firmly in a position of economic subordination" (p. 67).

\section{Women's Economic Activities}

The number of women participating in wage employment in Kenya continues to be low (Economic Survey, 1992). The current employment patterns of women have historical, cultural, social, economic and political underpinnings. Stamp (1989) argues that central to the nature of African society before colonialism was the prominent role of women in economic production. African women had substantial rights to control the means of production and own the product of their labour. Women in pre-colonial Kenya exercised political authority, as sisters of their natal lineage and through their elders' organizations in their marital lineage. With the colonial, postcolonial and neocolonial eras, women have lost their traditional autonomy and authority (Stamp, 1989; Boserup, 1970).

Robertson (1986) argues that colonialism introduced urbanization and intensified class and gender differences that existed in precapitalist societies. Cash cropping was introduced mainly to men, who also found more opportunities for wage labour. Pressured by the need to pay taxes, virtually everyone was brought directly or indirectly into the nexus of a commercial economy. Colonialism introduced new mechanisms of exploitation and imposed aspects of Western culture--Christianity, formal education, western technology, higher living standards for the new upper class, and new forms of patriarchal ideology and practice. These have all had a negative impact on the social status of most women in Africa. 
Robertson (1986) points out that:

As European sexism was added to patriarchal elements in indigenous cultures, sex roles changed to the detriment of women and they lost political power. While women retained responsibility for feeding their families, the prevalence of male labour migration in many areas left them to do even more of the agricultural work. Colonialism not only exacerbated inequality, but ultimately turned over governmental mechanisms of extracting wealth to new African ruling classes [after independence]. (p. 6)

Colonialism introduced private and public dichotomies in Kenya and mechanisms which drew men into the public space and limited women's participation within the private sphere.

A study of early wage earners in Kenya by Stitchter (1976) shows that opportunities for paid employment were provided by the colonial administrators along gender and racial lines. Men constituted the major source of labour migration but women performed the tasks arising out of the relationship between male wage-earning and the family. The interplay between traditional and the newly emergent division of labour forced women to remain at home subsidizing the husband's wage through expanded agricultural and trading activities in addition to their household and childrearing tasks. Stitchter (1976) notes that:

Large scale entry of women into the labour force was precluded under the migrant resident labour system because the low wages paid to men depended on the continuance of women's subsistence production. . . there were few opportunities for wage employment in urban areas for women. (quoted in ILO, 1986 Report, pp. 1-2)

Most women entered wage employment only after World War II in large scale agriculture where they worked as casuals on seasonal basis. The non-agricultural labour wage force occupations in which women were absorbed were mostly as domestic servants 
as a result of a policy aimed at "freeing " men from "this unproductive sphere of employment [for] which women are far more suited" (Obbo, 1980; ILO 1986 Report).

The gender segregated workforce that exists today can also be traced to postcolonial policies that regulated entry into the formal employment sector. For example, an examination of postcolonial career training policies for producing highly skilled African/Kenyan personnel for the modern formal sector reveals the reinforcement of an institutionalized gender segregated workforce. In the document entitled "Helping you choose a career" produced by the Kenyanization of Personnel Bureau in 1968, a list was given of career opportunities available in government and private companies. The prerequisites included sex, age, educational credentials and subjects in that order. Only two of the 150 careers in the formal employment sector were open to "girls only". These were careers in nursing and in secretarial work. Over half of the career opportunities were open to "boys or men only." The rest were open to both girls and boys and a majority of them required good passes in science and mathematics (Republic of Kenya: Ministry of Labour, 1968). Even though the latter careers were "open" to girls, the prerequisites of age and good passes in science and mathematics and the prevailing gender relations eliminated girls in the competition for career training and participation in the formal employment sector.

Although overt gender discrimination policies in the provision of employment opportunities have been replaced with supposedly gender neutral ones, women are still trapped in female preserves of employment. Feldman (1983) argues that in Kenya the prevailing gender relations and the ideology legitimating them continue to prevent women 
from moving into existing male preserves of employment which, not coincidentally, also command relatively higher wages than those women have been permitted. This can be associated with women's lack of scientific and technical skills and discrimination against women in the labour market. Feldman (1983) notes that:

Although Kenyan women are juridically equal to men before the law, their legal status is in many respects characterised by assumptions of dependence on men, which are expressed not only in marriage and divorce laws, but also in contract law, property law, and even some aspects of criminal law. . . . Despite apparent equality before the law, then this assumption of dependence effectively discriminates against women, and there is no law in Kenya which protects against sex discrimination as such. (p. 69)

At present sex discrimination is not illegal in Kenya and women find it difficult to challenge laws and policies that discriminate against them on the basis of sex. Section 82 of the constitution of Kenya allows discrimination by sex (UNICEF/GOF, 1992).

Current analysis of wage employment by industry and sex shows that female participation as a proportion of total formal/modern ${ }^{4}$ sector employment in 1989 was $20.9 \%$, the same level as in 1988 . Males accounted for $79.1 \%$ of total formal employment and dominated in all industries. The highest number of males were employed in agriculture and forestry, manufacturing, education services and public administration (Economic Survey, 1990). By 1991 the proportion of females employed in the formal employment sector had grown to 22.1\% (Economic Survey, 1992). Most women are economically active in the informal sector in agriculture, crafts, or commerce as low level, self-employed producers or traders. They are rarely in the new economic sectors

\footnotetext{
${ }^{4}$ Formal and informal sectors are two contrasting sectors that exist in the economy. The former is more organized and modern in nature. It is characterised by capital intensive technology and has high wages for its employees, large scale operations and corporate or governmental organization. The latter is mostly unorganized. Traditionally, its employees have less education, and are unskilled and lowly paid. The sector is labour intensive (Women's Bureau/SIDA, 1993).
} 
considered vital for future economic development such as manufacturing, science, technology and communications.

Women in the formal employment sector predominate in secretarial work, nursing, primary school teaching, and unskilled and casual work. In all these occupations, women earn significantly less than their male counterparts. Comparisons of men's and women's earnings in regular employment conceal the fact that "over a fifth of women employed in the formal sector are employed as casuals, and hence in worse conditions with worse terms of service than regular employees" (ILO, Jobs and Skills Programme for Africa (JASPA), 1981, pp. 5-6). Women's total average earnings amount to less than half (49\%) of men's. In the urban labour market that absorbs most of the workforce and offers secure, relatively well paid work (full time, paid work in formal sector) women's earnings are $55 \%$ of men's (1991 ILO Report). In 1988, 92.6\% of most senior civil servants were men and earned the highest salaries in the civil service scale. Women constituted $25 \%$ of all civil servants in 1988 and $92 \%$ of them were in Job Group G (salary level) and below, the higher rank being Group $\mathrm{T}$ and the lowest being Group A. Only $8.2 \%$ of females were on or above Job Group $\mathrm{H}$, the starting scale for most university graduates ${ }^{5}$ (Women's Bureau/SIDA, 1993, p. 12).

Women are also active in the informal non-farm sector, where in 1990 they constituted about $28 \%$ of the total wage employment (ILO Report, 1991). This sector includes small scale workshop, manufacturing, commerce and retail trade. Income generation in the informal sector continues to be of special importance and interest to women because they are discriminated against in access to formal sector employment and

\footnotetext{
${ }^{5}$ In Kenya the term "graduate" refers individuals who have completed university level of education.
} 
entry into the informal sector is easier, especially for self-employment. Urban women who head households are heavily dependent for livelihood on the informal sector. They cannot afford to be unemployed and they take whatever work they can find (ILO Report, 1991). Women, however, are underrepresented in the informal sector enterprises because they lack the skills and capital required for self-employment.

Women living in the rural areas are multiply disadvantaged when it comes to wage employment. These women have less formal education to compete in the formal employment sector. The rural-urban development dichotomy, with an emphasis on an urban-based formal employment sector, has made it difficult for women to participate in wage employment. The concentration of both the formal and informal employment sectors in the urban areas has left rural areas with minimum employment opportunities. Because of the unavailability of employment and the demanding gender specific roles that occupy women's daily lives, their employment participation rates in the rural areas are less than in the urban areas (JASPA, 1981). The dichotomy between "man the producer" and "woman the reproducer" is accentuated, though in reality rural women assume functions well beyond the role usually associated with a "housewife." In rural areas in most parts of Africa, women do $30 \%$ of ploughing, $50 \%$ of planting, $60 \%$ of livestock work, $60 \%$ of harvesting, $70 \%$ of weeding, $85 \%$ of processing and storing and $95 \%$ of domestic work (Chlebowska, 1990).

The tasks that women do have increased in difficulty and intensity with the migration of men to the cities in search of employment, increased primary education of children, particularly girls, and population pressure which has resulted in more intensive land use. Whilst women 
bear all the domestic responsibilities, they are often forced to carry out extra work such as traditional beer brewing ${ }^{6}$ or hiring themselves out as casual labourers on neighbouring farms in order to meet household financial needs (JASPA, 1981). Feldman (1983) points out that rural women in Kenya are burdened by heavy workloads which impede their participation in economic activities.

Some women in the rural areas find employment in the agricultural sector in plantations and farms. In 1990 women represented $23 \%$ of the work force in this sector, where over $50 \%$ of them were employed as casuals and on a seasonal basis (Economic Survey, 1991, JASPA, 1981). The 1981 ILO study on Kenyan rural women's employment opportunities examined women's employment patterns and their working conditions in factories, farms and plantations located in rural areas. The study found that (a) women's work in the farms and plantations was generally unskilled; (b) a disproportionately high number of women were employed on casual terms; (c) women received low pay; (d) women were excluded from promotion; (e) women were excluded from supervisory positions; (f) gendered assumptions were used to rationalize women's inferior positions in employment. Women were seen as working to supplement their husbands' wages rather than working in their own right. The view that women only work as wives is used to justify the casual conditions under which women are employed in the farms and plantations.

It is important to note that very few rural women have found employment in these plantations and farms because these employment opportunities are limited to a few geographical regions. Only $17 \%$ of Kenya is arable land, and Kilome division, which is the

\footnotetext{
${ }^{6} \mathrm{Few}$ women can earn any income from traditional beer brewing because it has been made illegal. Illegal brewers, however, do exist. The only person authorized to brew traditional beer is the wealthy retired commander of the armed forces, who is the current Minister for Lands and Settlement.
} 
region of Kenya where I collected data for this study, lies outside these regions. There are no farms and plantations in Kilome division and/or in the neighbouring divisions in which women can find wage employment. Kilome women have stringent, more limited income opportunities than those women in regions where there are big farms, plantations or factories. Thus, women's conditions are structured by complex situations that have similarities as well as differences. Just as women are not a monolith, rural women cannot be assumed to be subject to similar situations irrespective of their setting.

With the limited employment opportunities for women, particularly for the women who form almost $80 \%$ of the rural population, land becomes an invaluable resource to women. Women who have access to arable land are able to generate income from smallhold farming. Women's independent access to land is crucial.

This is especially a problem for women who are single heads of households and for other women who suffer from the fact that under land reform legislation, land in Kenya is almost exclusively allocated to men. Access is not guaranteed to those in whose name the land is not registered but who have traditionally had the right to use it, especially female relatives (wives, mothers, sisters, unmarried daughters). As population pressure reduces the size of plots, this lack of security to women makes them very vulnerable to landlessness. (JASPA report, 1981, p. 3)

Without land women cannot plant food to feed their families. In addition, they cannot acquire credit since land is the only property that rural people can use as collateral. Women's farm income, particularly in female-headed households is limited by size of accessible holding and access to labour and farm machinery. Women who live with their husbands face the problem of overall farm resources and of the distribution of income realized through crop sales. Although women contribute almost all the labour towards cultivation, they do not have automatic right to the use of the income from the sale of cash 
crops. The need for women to feed, clothe and educate their children demands that they involve themselves in other income activities such as being casual labourers or cultivating food crops and vegetables which they sell to neighbours and in local markets. These needs have increased the workload for women.

\section{Women and the Family}

Studies of African families in precolonial times allude to a gender based sharp division of labour in the family (Muthiani, 1973). Most of the ethnic groups in Kenya practiced a bridewealth marriage system. Through marriage, women were (and still are) affiliated to their husband's patrilineage and secured lineage membership for their offspring. Hakansson (1988) studied the Abagusii bridewealth system and concluded that the man was the head of the household and made decisions that affected the family. He built a house for his wife or wives, cleared the bush, and prepared land for her and assisted in cultivation. The wife was expected to obey her husband's directives, perform agricultural tasks, execute all manner of household chores, cook for her family and for visitors, and behave respectfully towards her husband's friends, relatives and parents. $\mathrm{He}$ concluded that "a wife was under the complete formal authority of her husband and no party outside the homestead could interfere with his treatment of her" (p.52). Stamp (1989) disputes the idea of an autonomous male head of household in bridewealth systems. She argues that in the complexity of the family in precolonial Africa, authority and power were not conterminous. "Relationships between fathers and sons, between brothers, between cowives and their husband, and between sisters and brothers made it very difficult to assign 'head of household' status to one individual" (p. 56). 
Stamp (1986 \&1989) points out that because many hand-hoe cultivating precolonial societies in Sub-Saharan Africa were patrilineal, a woman's social status was closely linked with bearing and rearing children within the family setting. A woman could be divorced but she could not divorce her husband. Among the Kamba, the ethnic group of the women who participated in my study, a woman could leave her husband temporarily. "Since social status was tied to social relations, divorce was rare because each side had to try all it could to keep the existing ties" (Muthiani, 1973, pp. 46-48).

In the modern setting, the image of a woman as a potential mother and wife remains. McAdoo \& Were (1987) argue that family life is very important for women and men in Kenya. Women still play important roles in family networks. The family, and in particular motherhood, offers a woman the opportunity for influence as both elder sister and mother of grown sons living in the same household. This implies that the concept of a family in the African context is complex. It is not a bounded unit of society that consists of a man and his family (Stamp, 1989). McAdoo and Were (1987) conclude that, despite urbanization and the influence of westernization, motherhood is still highly valued by most women in Kenya. In Kenya, motherhood is a powerful conceptual weapon used by both progressive and conservative forces in the battle to define women's political and social place (Stamp,1995).

Regardless of what benefits motherhood accrues to women, in the present setting women continue to bear the main responsibility for the welfare of families and they are responsible for the provision of the physical labour required to accomplish these domestic tasks. In the present social, economic and political circumstances in Kenya, the responsibilities of women, and mothers and wives in particular, have increased 
tremendously. In colonial and postcolonial times, the sexual division of labour along gender lines has become a relationship of dominance and exploitation of women in their provision of non-wage labour (Freeman, 1988).

Kenyan women's experiences of labour both in the private and public sphere are not uniform. For instance, the domestic tasks of urban, middle-class, educated, waged Kenyan women could not be similar to those of peasant women living in the rural areas or in the urban slums of Nairobi. Women's experiences are structured by class, culture, religion and other ideological institutions and frameworks (Mohanty, 1991).

Stitcher's (1988) study on middle class families in Nairobi found that domestic work is still considered a woman's responsibility. Even though an employed woman can employ a housegirl (maid) to provide child care as well as help with the domestic work, the wife is by far the principal person responsible for domestic work. Stichter argues that domestic work, child care and modern values have increased the amount of time in put considered necessary. She notes that:

The middle-class mother often feels she should set aside time specifically for child socialization, particularly to prepare children early for the highly competitive school system. But she has little time for such work; employment cannot be combined with child care as it can in a peasant society. ... Many middle income women express worry about the discrepancy between their ideals of child-rearing and the time they are able to give to it. In particular, they worry about the influence of the housegirl on the children since she is the one who spends the most time with them when they are young. (pp. 196-97)

Despite the help that a middle-class working wife gets from the housegirl or maid, Stichter's study found that the wife is the person who most frequently prepares and serves meals, purchases food, does the washing, and takes care of the children in the evening. The housegirl's range of work is limited and the husband's contribution to household 
work is negligible. Stichter notes that husbands will help take children to school if they have a car. $^{7}$

A working wife and mother is responsible for finding a housegirl to help out with domestic work. This means that if the housegirl leaves, which is often the case, the woman has to arrange for alternate childcare until she finds a replacement. She is the one to miss work if no alternative childcare can be made and to travel to the rural areas to find a housegirl. As Stichter (1988) points out,

The housegirl system poses a number of labour management problems for the wife. The first is finding and retaining a housegirl in a situation of fairly high turnover. This is normally the wife's responsibility, and it may involve a trip to the rural area. If a housegirl leaves, the wife may have to lose a week or so of work finding another one, with the result that her employer will be annoyed and inconvenienced. (p. 199)

Consequently, women face tremendous pressure to balance their careers and the traditional homemaker roles. Women in Kenya are caught up in the dilemma of accomplishing their roles as mothers and workers under the present definitions. Kenyan women are involved in a struggle to gain a living and satisfy the social and cultural "worlds" they occupy (Johnson \& Bernstein, 1984).

Mothers must organize domestic help so that they may participate in paid employment. Working women then worry about the quality of care that their children receive from the poorly educated housegirls who care for their children while they are at

\footnotetext{
${ }^{7}$ I find it hard to believe Stitcher's observations that husbands are more likely to take children to school if they have a car. I have lived in both of the estates where Stichter did her research in Nairobi from 1973-88. During this time I saw a good number of men with their children waiting for public transport (matatus minibuses) to take their children to school and then proceed to their offices. However, traveling in Nairobi in the morning is a nightmare. Therefore, many parents avoid enrolling their children in schools that are far from their homes which require the children to take public means since the city has no special transport for children. The other solution has been to pay for private transport for the children.
} 
work (Stitcher, 1988). Mothers are struggling to balance these doubly important roles which in most cases becomes an impossibility because of the separation between the home and the work place. The work space is not organized to take in account the women's numerous responsibilities as wives, mothers, workers and all other responsibilities that women undertake as members of extended families. The separation between the public and private spheres limit women's participation in wage employment. It also gives employers the leeway to discriminate and exploit women as workers. Women are denied positions of power on claims that their gender roles as mothers and wives make them unsuitable for such positions. In the present setting, elements of patrilineal sexual division of labour from precapitalist societies have been retained in dominated and distorted forms and combined with Victorian and Christian notions of male superiority to create an image of women that reflects inferiority (Obbo, 1980; Stamp, 1989).

In the household, an employed wife is faced with contradictions as she is viewed with ambivalence (Munachonga, 1988). On one side her income is perceived as having financial advantages for her husband because it relieves his economic burdens and enables him to keep more of his earnings for personal use or on other wives he may have since polygymy is sanctioned under customary law. At the same time, the wife's access to independent income is considered to have a negative effect on marriage and family stability (Munachonga, 1988). For many women, maintaining a balance between a successful career and making a home is a stressful exercise. "It is like swimming against the current" (Kiiti, 1993, p.17). Therefore, even those women who acquire education and become 
economic agents in the public sphere continue to be primarily responsible for domestic chores in the private sphere.

For women in the rural areas, their non-waged activities are almost limitless. They perform the bulk of domestic work which includes subsistence agriculture, childrearing, care for the aged and sick, housework and all other work required to sustain the household. Women's reproductive and productive roles have been intensified with male migration from the rural areas. This phenomenon has resulted in de facto female heads of households where husbands are away for long periods of time leaving the wife to support the family, although there may be income from the husband irregularly (Due, 1991).

Stamp (1986) argues that rural women are the backbone of Kenyan peasantry and are doubly dominated as peasants who are a dominated class within underdeveloped capitalism, and as women who are a dominated category within the peasantry. Rural women's labour is exploited to maintain the unequal exchange of primary commodities on the international markets (Stamp, 1989). Wages in underdeveloped countries are rarely sufficient to support a family; therefore, women are expected to engage in subsistence agriculture for the survival of the family. The provision of non-waged labour by women, the growing of food for subsistence and sale on marginal land, is necessary for the continuation of the unequal exchange upon which the sale of primary commodities on the world market is based (Freeman, 1988).

Women are expected to produce food crops to support their families and are also expected to produce commodity surplus which their husbands may then appropriate. The network of laws and economic practices by the state in Kenya sanctions or requires this 
appropriation through the land consolidation and cash crop farming and marketing organizations. Since the 1950 s land has been transferred from lineage ownership to male heads of households. This has legally made the product of the land the property of the individual husband even though women carry the burden of production for no wage (Stamp, 1989).

An examination of women's individual and group activities in Kenya reveals, however, concerted efforts by women to retain control of their work and products of it. In Kenya, women's resistance to the appropriation of their labour by men and the state has taken many forms including refusal to adopt new cultivation practices, refusal to grow certain crops or cutting back on their production. Stamp (1989) points out that the channeling of women's earnings into self-help groups is a form of resistance by women to the appropriation of their labour by the international commodity market through the agency of their husbands or male relatives.

\section{Women's Self-Help groups}

Women in rural communities are using pre-colonial gender based organizing strategies to form women's self-help groups to cope, shape and resist their social conditions characterised by harsh economic, social and political changes. Women's self-help groups in the traditional setting became necessary as a collective geared at identifying a task and putting their resources together to work on the task (Republic of Kenya: Women's Bureau, 1992). Women's customary organizations, such as age-groups for the Kikuyu, Myethya or work parties for the Kamba, have developed into self-help groups with new functions overlaying the old (Stamp, 
1986). The original objectives and aims of the traditional organizations have changed to accommodate the rapid political and socio-economic changes taking place in the country.

Women's self-help groups have grown to be associated with the harambee or community self-help movement whose main objective is mobilizing and revitalizing Kenyans in the development process of the country. The Ministry of Social Services defines a women's group as a voluntary self-help group of more than fifteen members made up exclusively of women or whose membership consists of an overwhelming majority of women. The Ministry adds that in those self-help groups that have men as members, it is the women who have to exercise decision making powers (Republic of Kenya: Women's Bureau, 1992). The underlying reason for women's self-help groups' formation and existence is the increasing burden assumed by women in the changing social division of labour. Women's self-help groups have risen as an instrument through which the individual member can strengthen her capabilities in meeting the challenges of being the chief provider for her family's welfare.

Women's self-help groups have emerged throughout much of the rural areas as a response to economic, social, political and technological changes arising from the colonial experience, participation in a cash economy, and from policies and politics of independent Kenya (Thomas, 1985). Women's self-help groups are involved in their own income generating activities, such as producing handicrafts for sale, or assisting in building community facilities. Typical activities of women's self-help groups include farming, milling maize, keeping livestock, making handicrafts and maintaining rental properties. They are also operating revolving loan schemes or credit. They extend credit to individual women who are associated 
in women's self-help groups and are pursuing small-scale enterprises (UNICEF/GOK 1992). They also provide loans to women for education and medical expenses.

Women's self-help groups are required to register with the Women's Bureau, Ministry of Social Services which was set up in 1975, the International Women's Year. This is a political move to control opposition to the government, thus limiting women's social and political power. The Women's Bureau has become both the effective focus for policies towards women and a major means of acquiring international funds for aid specifically directed at women (Feldman, 1983).

In her study that focused on women's self-help groups in Murang'a, Kenya, Ahlberg-Maina (1991) argues that dominated women's self-help groups in rural Kenya are still an important resource for change. She posits that in the context of Kenyan history, women have continued to exploit the power of collective action to counteract negative forces within the system even after colonial forces had disrupted their culture and collective organization.

Continued collective participation of women has not just offered a link between the past and the present, it constitutes a process of consciously selecting positive cultural traits and adapting them to meet new challenges. It is perhaps only through such dynamic participation that issues which evoke resistance can become an integral part of the collective activity and social order. (Ahlberg-Maina, 1991, p. 187)

Stamp (1986) argues that women's self-help groups are not simply about cooperative development projects, or strategies for coping with change, rather, they are vital organizations for resistance to exploitation. She argues that by women channeling the cash from crops into self-help organizations, they are preventing appropriation of their product by their husbands. Their attempt to "accumulate capital is a means of protecting 
and enhancing their fragile incomes and compensating for lost domestic production" (Stamp, 1986, 40). Consequently, women have become agents of resistance and change in the maelstrom of contemporary Kenyan affairs. Their agency resides in their communal endeavours and is constantly reinvented in the context of political and social changes (Stamp 1995).

\section{Conclusions}

This examination of Kenyan women's participation in education, economy, family and in the general society shows that women's experiences are structured by gender and power relations that limit their access to equal opportunities. These gender and power relations in Kenya are related to the historical, cultural, economic and political legacies of society. The colonial economy that was imposed on indigenous Kenyans dismantled cultural values and customs which supported African social systems. Colonial administrators, who were invariably men, brought their assumptions of male supremacy with them. They did not seek spokeswomen or head-women but spokesmen and headmen. When the need for semi-skilled workers developed, young boys were sought for schooling. The political power of women was not recognized by Westerners because it was always indirect, often a function of their position as sisters or mothers. Under the increasingly stringent and competitive circumstances of postcolonial capitalism, patrilineages are becoming more patriarchal, intensifying control over lineage wives and undermining the power and rights to resources of lineage sisters (Stamp, 1991; Boserup, 1970). Precapitalist dominant gender relations have been manipulated to exploit and dominate women and deny them social, economic and political power in present day Kenya. 
Present patterns of women's participation in education and formal employment show that these institutions are still gender segregated. Parity in enrolments of girls and boys at the primary level are accompanied by high drop out rates of girls due to pregnancy, child marriages and high fees charged as a result of the implementation of costsharing strategy. At the secondary level girls continue to attend schools of poor quality in disproportionately high numbers and have restricted access to a broad range of curricula, particularly in sciences. They are conditioned to biased learning materials and classroom dynamics.

Women's participation in employment has similar patterns. Women represent about $22 \%$ of the total formal wage employment. The demand for educational credentials, discrimination against women and maintenance of sharp division of labour in the family continue to keep women out of the those more generally lucrative careers and out of the formal employment sector. Women living in the rural areas have less employment opportunities than their urban educated female counterparts.

Rural women, who do not have educational credentials and resources such as access to land, are seriously disadvantaged. The rural-urban dichotomy severely limits their opportunities for employment. These women's participation in income generating opportunities is limited by the conglomerate of labour intensive non-waged activities that they engage in for their family's survival.

Women have become intervention agents and buffers for their families from the effects of the social, economic and political crises that have befallen Africa with little or no support from their governments. The government of Kenya, for example, has continued to 
deny reports that show that women are overtly discriminated against. It has consistently maintained the position that Kenya women are not discriminated against and therefore do not need to struggle for rights for they are already enjoying them. Sweeping and vaguely worded statements of government commitment and intentions about women in development are expressed in national development plans and party manifestos (Nzomo, 1989). As Staudt and Gluckman (1989) observe, the Nairobi meeting to conclude "the United Nations Decade for Women in 1985 signalled no dramatic changes in African governments' responsiveness to women or in women's voice in the political process" (p. 4). Women in Kenya continue to be encumbered by a plethora of gender barriers to educational, economic and political opportunities, making gender and power crucial categories of analysis in any attempt to understand and address gender inequities in Kenya.

In the exploration of rural women's educational experiences and their role as intervention agents for their children; there is no available literature to illustrate such agency, particularly for daughters whose educational and economic opportunities are denied them due to social, cultural, economic and political factors. Therefore, this study which explores rural women's educational experiences and their role as intervention agents for their children from the women's standpoints is crucial. 


\section{Chapter Three}

\section{Methodology}

This chapter deals with the methodology of my study of women's experiences of educational policies in the Kilome division of Kenya. Women's voices and concerns have been excluded in the official discourse on education and development articulated in policy documents. This exclusion has led to the formulation not only of gender biased policies but also of seemingly gender neutral policies that have served to exacerbate gender inequalities in Kenya. In this study, rural women were provided space to narrate their experiences of education from their own standpoints. Women were encouraged to articulate their thoughts, fears and hopes on the subjects of education, paid and unpaid work, family and sexuality. The women's narratives were construed as private or female discourse on education. I later juxtaposed the private discourse alongside the public discourse on education highlighting the contradictions and similarities between the different narrative standpoints..

In this chapter, discussion on theory guiding how the research should proceed is followed by a description of the process and the research sites. Next, I discuss the participants, research topics and translation of the interviews followed by an examination

of issues around writing ethnography. Last, I reflect on doing research as both an insider and outsider in Kilome division. 


\section{Theoretical Framework}

Distinctions between supposed public and private spheres of human existence have generated a lot of controversy. Jaggar (1983) points out that traditional political theory has always made a distinction between the public and the private spheres of human existence. She notes that political theorists, though unable to agree on where the line between public and private spheres should be drawn, have unanimously agreed that the areas of sexuality, childbearing and childrearing should be defined as the private sphere because these activities have been conceived as natural or biologically determined. Jaggar concludes that:

When so much of the work in the 'private' realm is invariably done by women, moreover, it is not just irrational but sexist to assume that women are biologically determined to continue performing this work. An adequate political theory must evaluate traditional sexual, childbearing and childrearing practices and consider more liberatory alternatives. (pp. 112-113)

Feminists critique the existing liberal political and economic theory that separates the public and private and that makes a distinction between the public "economic world of the market" and the private, "non-economic" sphere of the home. The distinction is value laden and has been used to rationalize the exploitation of women (Jaggar, 1983). Women's labour is crucial in enhancing social, economic and political development of any state in the public sphere.

Critics question the universality of the public/private distinctions. Stamp (1989) argues that the assumed Western conceptualization of the public/private dichotomies of "human existence" is an inaccurate conceptualization of present and, even more so, past African life. She points out that Western notions of public and private distinctions cannot be 
used to understand African communities. Stamp argues that the community of most African women is as full a participant in the decision-making structure of village life as is the community of men. She argues that women's voices are silent not because women participate only in the private sphere but due to the privileged status of the community of men gained through contemporary socioeconomic processes. Stamp posits that, although women are largely absent from contemporary national and "formal" political institutions, their political efficacy continues to be manifested at the community level.

In this study, the public and private distinctions are useful in understanding and differentiating the nature of the public or formal sphere where policies are formulated and the private sphere where rural women's agency is confined. Women are largely absent at the contemporary national level where policies are formulated. The women's discourses at the local level, though public at the community level as exemplified by their activities as individuals and as collectives, do not inform the larger "authentic" or legitimated discourses that are articulated in policy documents. Van Allen (1976) argues for a notion of public which relates to the collectivity of decision making where a few individuals may possess the knowledge required to make decisions at the public level. He notes that,

The settling of questions that concern the welfare of the community in a "public" way necessitates the sharing of 'political knowledge'--the knowledge needed for participation in political discussion and decision. A system in which public policy is made publicly and the relevant knowledge is shared widely contrasts sharply with those systems in which a privileged few possess the relevant knowledge-whether priestly mysteries or bureaucratic expertise--and therefore control policy decisions. (quoted in Stamp, 1989, p. 115) 
The nature of collectivity and the space or style in which that collectivity operates, are important distinctions of public and private spheres. In Kenya women operate in the spheres that have been rendered less visible by contemporary male-dominated structures and discourses. Inevitably, the community of men has been favoured over the community of women. Men have had the privilege to make decisions at the public level that affect all people. In the African context, these public/private distinctions have taken root because

Outsiders, from missionaries to colonial officials to contemporary governmental elites, have recognized men's networks as the sole, legitimate 'public' with which they should deal--the uniform, undifferentiated 'public' that embodies 'public interest. (Stamp, 1989, p. 116)

Public discourse articulated in policy documents is produced and disseminated by mainly the community of men in the contemporary state through state sponsored strategies. It is the legitimate and dominant discourse on education. The private discourses on education produced by women are produced mostly at the individual level and to a lesser extent at the group level. The women's discourses are primarily the women's lived experiences existing at "private/informal" world of "women's affairs." However, discourse is not neutral. As Apple points out, "all our discourses are politically uninnocent and occur within shifting and dynamic social context in which the existence of multiple sets of power [and gender relations] are inevitable" (Apple, Introduction to Lather 1991, p.vii). Power, Focault argues, is not a property but a strategy which is constantly in tension and in activity. Consequently public discourses and private discourses on education interact in complex ways as exemplified in the Kilome women's actions in shaping and transforming their children's and particularly, daughters' experiences of educational and development policies produced at the national level. The women are not mere victims of 
public policy discourses but they act upon these policies as individuals and as collectives. They interact within the constraints and opportunities of existing structures at the same time as they act upon and restructure the social system.

This study involves women at the grassroots level. Stamp (1986) describes these women as the backbone of the Kenyan peasantry who are doubly dominated as peasants within underdeveloped capitalism and as a dominated category within the peasantry. Despite the crucial role that these women play in the society, their realities have continued to be invisible in public discourses covering all aspects of the society and specifically, in the education discourse in Kenya. Paulo Freire (1990) argues that "reality" is never simply objective datum, or concrete fact, but is also people's and certain people's perception of it because of the indispensable unity between subjectivity and objectivity in the act of knowing. Reality is not independent of our experiences and thus social, economic, cultural and political factors play a big role in shaping people's reality. The reality of women's and men's lives is shaped by the complex interactions of the social, political, economic, cultural and historical contexts of the particular society.

Feminists have shown that women's experiences have either been ignored or distorted (Eichler, 1983, Harding, 1986). More importantly, eurocentricity and the desire to use western values as yardsticks have produced the "third world woman" as a singular monolithic subject--a stereotype that has worked to her detriment (Mohanty, 1991). Kenyan women's delineation of their reality from their standpoints is important in countering the hegemonic perceptions of women that have portrayed them as stereotypical pawns of men. 
Stamp (1995) argues that a text on African women's agency must ask new questions, ones that aim to elicit what women are doing as active agents of resistance and change in the maelstrom of contemporary African affairs. Potash (1989), writing about gender relations in African societies, argues that it is crucial that we begin to ask questions that make visible the complexities of women's and men's relationships. We must ask questions that portray the "reality" of women's lives as social actors who use systems to achieve their ends. Potash concludes that "such praxis approaches emphasize human resourcefulness while recognizing systemic limitations" (p. 191).

Ahlberg-Maina (1991) concurs with Stamp and Potash about the importance of taking African women as actors contrary to the passive image of African women portrayed in most contemporary literature. In her study of the response of women's groups to family planning programmes in Kenya, Ahlberg-Maina used the actor-systems-dynamics analytical framework to understand women's experiences. "The actor-systems-dynamics approach recognizes the dynamics of social actors whether individuals or collectives in social structuration and transformation" (Ahlberg-Maina, 1991, p. 32). Ahlberg-Maina argues that this approach makes visible women's actions in the formulation of strategies aimed at influencing and/or shaping the system in which they are a part. She notes that, as social actors, women are engaged in the making of their own history, a process which is not only continuous, but one where past experiences, knowledge and cultural traits are carried along. Ahlberg-Maina concludes that, even as a dominated group, women are a dynamic force in the shaping of the social system and its change. This strategy makes visible the different forms of struggle and resistance that women engage in their daily lives. 
The women in this study are social actors, who formulate strategies aimed at influencing or shaping the social system in which they are a part (Ahlberg-Maina, 1991). They interact within the constraints and opportunities of existing structures at the same time as they act upon and restructure the social system. These women's agency resides in their individual and communal endeavours and is constantly reinvented in the context of political and social change (Stamp, 1995).

For the women's agency to become visible they must participate in the study as who they really are--subjects and knowers. Harding (1986) emphasizes the importance of taking women as subjects and knowers rather than as the objects of study as has been the pattern in many conventional research methodologies. As knowers the women participate in knowledge production through participation, dialogue and analyses of discourses/discussions (Fals-Borda \& Rahman, 1991). The women in this study not only participated as knowers and subjects but also their voices as subjects of inquiry, and the voice of the inquirer are culturally identifiable. This created the possibility of understanding the women's condition as well as my own from the standpoint of historically and culturally locatable experiences (Smith, 1987).

Many research methodologists, particularly postpositivists, advocate reciprocity of research. Patti Lather (1986) argues that participants should gain self-understanding and, ideally, self-determination through the research. The methodology of this study made reciprocity a viable objective. The women's understanding of the dynamics of gender inequities in accessing educational opportunities and self-determination is evident in the goals of the women's self-help groups, both old and newly formed groups since my 
research, and in the systematic progress that the women have made in achieving these goals. The women have kept me informed of their activities by writing to me on a monthly basis. The women's actions as a group and as individuals have created the possibility for transformation of their own and their children's world or "reality." The research process has contributed to the re/orientation, focus and energization of participants in what Freire (1973) termed "conscientization," knowing reality in order to better transform it. Mies (1983) argues that active collective consciousness becomes possible only when women can use their own documented (spoken), understood and analyzed history as a "weapon" in the struggle for themselves.

Mies (1983) also notes the importance of creating a wider network of communication for women from different villages/locations or cities. She argues that a research project should be linked to an ongoing movement. Mies argues that "a research project that does not link up with some local group which can become a permanent base for conscientization, mobilization and action will remain at best a pleasant episode in the lives of the women" (p. 137).

Smith (1987) observes that research for women must begin from the standpoints of women. Such an inquiry regards women's experience as starting and ending points for inquiry. Alcoff (1991) states that anyone who speaks for others should only do so out of a concrete analysis of the particular power relations and discursive effects involved. Leslie Roman (1993) argues that "the concept of speaking with conveys the possibility of tendential and shifting alliances between speakers from different unequally located groups" 
(p. 184). In the study I struggle to speak with the women while being conscious of Alcoff's cautions on the problematic of speaking for and about others.

A study encompassing the above dimensions can only become possible within methodological paradigms that are political and, as Patti Lather (1986) argues, ones that are openly ideological. My research methodology is informed by feminist research methodology paradigms, particularly by standpoint feminists (Smith, Harding, Jaggar, Roman), postmodern feminists' epistemologies (Lather), third world feminist perspectives (Ahlberg-Maina and Mohanty), critical theorist/emancipatory discourses (Freire, Apple) and postcolonial and Africanist discourses (Potash, Stamp and Mies). This study combines these methodological perspectives in order to explore women's agency and the systemic limitations women encounter in their attempt to achieve educational and economic opportunities in Kenya.

Feminism as a political movement struggles for methodologies that can bring women's experiences to light and put such experiences on the political agenda (Mies, 1983). What I have striven for are methodologies that are informed by epistemologies that consider women as knowers and active agents of social change, not mere victims. These methodologies must also consider gender, race, class, and ethnicity as vital categories of analysis in understanding women's material standpoints.

The complexities of feminism as a political movement aimed at addressing women's issues are intensified by the fact that the female subject is herself a site of differences. Mohanty (1991) takes Western feminists to task for having asked the wrong 
questions and thereby producing "the third world woman" as a singular monolithic subject.

Mohanty (1991) posits that:

Assumptions of privilege and ethnocentric universality, on the one hand, and inadequate self-consciousness about the effect of Western scholarship on 'third world' in the context of a world system dominated by the West, on the other, characterize a sizable extent of Western feminist work on women in the third world. . . . Marginal or not, this writing has political effects and implications beyond the immediate feminist or disciplinary audience. (p. 53)

The consequences of distortion of women's lives have been reflected in the development enterprise discourse and policies on third world women. Discourses ranging from academic writing to the design, implementation and monitoring of aid projects by public and private agencies reaffirm a view of African women as passive, problematic targets of benevolent intervention (Stamp, 1995). Davies and Graves (1986) argue that the portrayal of the African woman as a supermother, a symbol of Africa, or as the one with a golden heart does not necessary counter the facile image of African women. The two authors argue "for a truthful assessment of women's lives, the negative and the positive and a demonstration of the specific choices that women must often make" (p. 15). A counter discourse involves making visible women's resistance as well as their compliance with the patriarchal structures that perpetuate their subordination. As Van Maanen (1988) argues, ethnographies are politically mediated, since the power of one group or researcher to represent another is always involved. Most crucially, ethnography irrevocably influences the interests and lives of the people represented in them both individually and collectively, for better or for worse. 
Guided by the above framework, aware of my own privileges of educational and socio-economic status, I entered the lives of the women of Kilome division to talk with them about their experiences of education. I worked with the women in their capacities as daughters, sisters, mothers and/or wives. I used gender as a category of analysis because

Insofar as women and men have been shown to participate differently in the economic, social, political,[education] and religious life of their societies, we cannot continue to describe institutions as if they are gender neutral when they are not. Rather, an understanding of social organization and social process requires new conceptualizations that use gender as an integral theme of analysis, not as a marginal category. By focusing on participatory patterns and the diverse interests and strategies of women and men we obtain a more realistic picture. Furthermore, since the allocation of rights and responsibilities among men and women have implications for their relationship to one another and to their society, such analyses hold promise for improving our understanding of gender systems. (Potash, 1989, p. 189)

\section{Research Design}

Harding (1986) points out that "method" deals with "techniques for gathering evidence" while "methodology" is a "theory and analysis of how research does or should proceed" (pp. 2-3). In order to make visible the gender and power issues that limit women's participation in education, economy and the wider Kenya society, it became important to involve the women, particularly those living in the rural areas. These women's struggles to participate in Kenyan society are exacerbated by the limited educational opportunities made available to them and the rural-urban dichotomy in the development of the formal employment sector. I chose to interview women who were born, raised, and who received part of their formal education in Kilome division, Makueni district, Kenya. I interviewed women about their experiences of formal education, highlighting the barriers that they faced in accessing educational opportunities as well as 
their daughters' limitations to educational and economic opportunities. I used audiotaping, field notes and twice I video-taped the women as they engaged in their group activities in the women's group. The women's narratives represent their private discourse on education which I use to discuss the public discourse on the role of education in development articulated in policy documents.

I also examined the policy documents produced over the last 30 year period in light of the political, social and economic rhetoric of the time. All the policy documents represent the government's position on the role of education in development. I examined the public discourse on education for the rationale for providing educational opportunities. I was interested in whether there is a commitment to provide women with educational opportunities equal to those of their male counterparts or whether women are only provided educational opportunities sufficient for improving delivery of services as mothers and/or wives in the private sphere. This analysis reveals the gendered and cultural assumptions of femininity and masculinity legitimated at the public national level. In addition, analyzing policy documents contextualizes the women's interviews and provides a better understanding of their subjectivities and subordination. It also makes visible how policies have limited and continue to limit women's agency in the public sphere.

I also looked for the similarities and differences in the policy documents' approach to addressing gender and power issues in relation to women's actual access to educational and employment opportunities. Gender representation in the commissions and work parties and the roles held by men and women (chairperson versus copy-typist scenario) were of importance to this study. 


\section{Reflexivity}

Hammersley \& Atkinson (1983) point out that it is important to recognize the reflexive nature of social research--that we are part of the social world we study. In addition, as researchers, we hold an explicitly political vision of the structural conditions that lead to particular social behaviours, a vision that our collaborators may not hold (Gluck \& Patai, 1991). Bell (1993) notes that ethnographers must first know themselves. In addition, Lather (1991) argues that in studies that are openly ideological self-reflexivity is essential.

I entered Kilome division, the site of my research, partly as an insider and outsider. I am a Mkamba, born in Uvuuni, a village in Kilome division, the child of Jonah Kiluva and Hannah Ndoti. I attended a local primary school and left the village school in 1973 to undertake my secondary level education in a city secondary school. I sat for the Kenya Primary Certificate of Education examinations in 1972, and was admitted to an harambee day school about 10 kilometres from my home and lived with relatives whose rural home was nearer to the school. My educational prospects would have been better if I had been called to join one of the government secondary schools in the country or attended Precious Blood, the only government girls' only school in Kilome division. Precious Blood girls secondary school takes only 6 girls from the three divisions of Makueni District, making the school very competitive.

The harambee school I joined, like most harambee schools, was very poor. There were no trained teachers, no facilities or equipment required to teach science and the vocational subjects that had been made compulsory. I stayed in this school for two months. Had it not 
been for my brother's intervention (who had graduated from high school and was working as a trainee accountant), I would certainly have failed my university entry examination if I had not dropped out of school before sitting for this examination. My brother found a space for me in Kenya High School, a former European girls' high school which charged higher fees. My brother paid my school fees for the six years I was a student in the school. School fees were a barrier to many girls, particularly, rural girls.

My experiences of education in the village primary school and in the high-cost high school were extremely different. In my primary school, which was coeducational, the teachers, mostly male in the upper primary level treated girls and boys differently. They intimidated, harassed and embarrassed girls, particularly those who were mature. Teachers picked on girls who did not raise their hands to answer questions and they showed a lot of disgust and impatience towards academically weak students, particularly those girls who had reached puberty. The classroom environment was always very tense and hostile. There was a tendency to portray girls as dumb. The treatment most girls received eroded their selfconfidence and self-esteem. The teaching methods were very traditional and teachers were autocratic and authoritarian. I do not remember any girl asking a question in the class! If you didn't understand when the teacher was teaching, you were doomed unless you had older siblings or relatives whom you could consult after school. Most of the girls in my class were the only ones in the school who had gone that far with formal education in their families. It is not surprising that most of these girls left school at the primary level and got married.

The shift from the rural life to an urban elite school, Kenya High School, was a big challenge for me. The world represented in the Kenya High was totally different from that I 
had known. I had grown up in the rural areas and most of the children in this urban school had grown up in the city. Our backgrounds were totally different. Most of the students who went to Kenya High came from elite homes with very different socioeconomic status from mine. Their background was reflected in their dress, language, attitudes and experiences that transversed nations. I was a village girl who had grown up in a polygamous home collecting firewood and water, digging, planting and harvesting. My peers/classmates had middle-class mothers as their role models, whereas my role models were completely different. It was a struggle to fit in this school. Nevertheless, once I reconciled the two "worlds," I began to tap the benefits of this environment. The teachers had high expectations of the students and girls aspired for higher education and challenging careers in science, science-related fields and in arts.

I wanted to become a medical doctor, therefore, I chose science and mathematics subjects for my advanced level education (grade 12 and 13 equivalent). After completing this level of education I was called to the university to undertake a B.Ed (science) degree.

I went to Kilome division, taking with me my two children aged eight and nine, to talk to some of the women about their experiences of education. I wanted the women to share with me their stories of formal education, highlighting the barriers that they faced and those that their children and in particular female children face. I wanted them to share how they were constructing educational possibilities for their children and girls in particular. This is why I made my journey to Kithumba and Kyandue villages and to Salama town in Kilome Division to talk to women who had not been as "fortunate" as I had been. My journey from Kilome to 
Kenya High School to Canada and back to Kilome would not have been possible without my brother's intervention.

My participation in the study and my "double identity" as a native of Kilome and a woman scholar committed to women's liberation and justice influenced the women's conceptualization of their subordination and agency. The discussions that I held with the women as individuals and as a group provided the space for the women to examine their compliance and to image out ways to challenge patriarchy. I found myself asking the women to move beyond "sacrificing" themselves to create solutions, but to also to begin to question and challenge the structures that perpetuate women's exploitation and subordination. I used my "double consciousness" of privilege and subordination, as an educated woman and as a Kenyan woman, as a methodological and political opportunity to challenge the women to question the structures that maintain their subordination (Mies, 1983).

This background shaped my choice of site and indeed influenced my discussions with the women of Kilome division. The discussions highlighted the women's experiences making visible the constraints that they face and their active participation in shaping their social conditions and those of their children.

\section{The Research Sites}

The research is set in Kilome division because of my own interests and relationship to the area and also because this region is a part of rural Kenya which illustrates the difficulties that rural women face in their attempt to participate in the educational, economic, social and political spheres of the society. The women's experiences here are issues that are of interest to 
me not only as an educator but also as a woman who was born and schooled in Kilome division.

My fieldwork took place in the Kithumba and Kyandue villages and in Salama, a small town along the Nairobi-Mombasa highway in Kilome Division, Makueni District. Makueni District is in the Eastern Province of the Republic of Kenya and is one of the six districts of this Province. Makueni District is divided into three divisions, namely, Kilome, Kibwezi and Makueni. Women in Kilome division belong to the Akamba ethnic group. A member of the Akamba ethnic group is called a Mukamba, many are Akamba or Kamba, the language is Kikamba and the region is Ukamba (Muthiani, 1973).

Kilome division lies about 130 kilometres south of Nairobi, the capital of Kenya. In 1990 Kilome division had a population density of 275 persons $/ \mathrm{km}^{2}$ or a total of approximately 241,900 people (Odiege, 1992). It borders Kajiando division to the west, Makueni to the east, Kibwezi to the south and Mbooni to the north. Kilome town is the divisional headquarters with a population of about $1500^{1}$ at present. The headquarters is a subsidiary of the office of the president and it houses the offices of the district officer, divisional social development assistant and a police station. The district officer is a presidential appointee. Kilome division is divided into locations and sub-locations which consist of several villages headed by a chief and assistant chiefs respectively. These positions have been held by men since their creation during the colonial era who are appointed by the Public Service Commission-the body in charge of hiring civil servants.

\footnotetext{
${ }^{1}$ This an estimate of the population of Kilome town since there are no official statistics.
} 


\section{Kithumba village}

Kithumba village is in Kilome Division of Makueni District. Kithumba village covers an area of about 12 square kilometres and has a population of about 4200 people. It is on the Kilome-Salama road, up the hills about 2.5 kilometres from Kilome Divisional headquarters where the district officer's (D.O) and other administrative offices are located. The KilomeSalama road, which passes through Kithumba is tarmacked. There is also a power-line which runs from Salama through Kithumba to Precious Blood Girls' School, the only government maintained girls' only secondary school in this division. This power-line was constructed after the president of Kenya visited the school and was impressed by the school's academic excellence. In the prevailing political climate in Kenya, the president's act was construed as a favour to his political stalwart, a senior civil servant whose home is a few kilometers to the south of Precious Blood Girls' School, located about 12 kilometres north-west of Kithumba village. An additional favour to tarmac the road from Nunguni to Precious Blood Girls School stalled and was eventually abandoned when this civil servant retired.

\section{Life in Kithumba Village}

Each family in Kithumba village owns a small plot ranging in size between $1-4$ acres. Each family plants maize and beans during the rainy seasons. Rainfall in the area is inadequate and unpredictable, a factor, which when combined with shallow soils, steep slopes and unstable surface soil structures, makes water and soil conservation a delicate issue. Consequently, harvests are poor and most families buy food (mainly maize and beans (isyo)--staple Akamba diet throughout the year. 
Women from Kithumba earn their income from small-scale agriculture, petty trading, casual work and participation in women's self-help groups. There are no big farms or plantations where women may find paid employment. Women utilize their plots efficiently and in most cases overuse their plots in their attempt to increase productivity. In a family's plot one can find (a) a section for subsistence crops, (b) vegetables, (c) poultry and (d) livestock, usually one cow and two goats. A few families have planted coffee, ${ }^{2}$ the only cash crop planted in this area. Some women in Kithumba village are petty traders. They sell excess farm produce, vegetables, chicken and eggs, and those who have cows sell milk to neighbours. Some take their commodities to the local markets which assemble on a weekly basis. Others take their commodities to several other markets within the division. Women's mobility depends on the age of their children, availability of help when she is away and, more importantly, permission from her husband.

Houses in the villages in Kilome division are similar. They are either made of mud with thatched roofs, mud with corrugated iron-sheets or bricks with corrugated iron-sheets. The quality of houses in Kithumba village is relatively high. Most of the houses have corrugated iron roofs. Few houses have thatched roofs, and I noticed a tile roofed house in this village. The nature of the house reflects the income bracket of the head of the household. Building timber is readily available. The Ministry of Environment's forest station is located a few

\footnotetext{
${ }^{2}$ The labour demands of this crop are high and women are responsible for it. Nevertheless, the coffee is registered in the name of the husband as the owner of the plot. Often women are not signatories to the account held at the cooperative. The few women who mentioned having had coffee pointed out that they were no longer willing to labour for nothing because they never saw the fruits of their labour. I met one woman in Kithumba who neglected her husband's coffee (as she called it) and concentrated on subsistence crops. She did this because her husband always collected the money from the cooperative to spend it with his other wife. She noted that she could not uproot it because it was not only against the law but she would also be killed by her husband. Stamp (1986) found similar resistance strategies employed by Kikuyu women.
} 
kilometres from this village. Here villagers can buy timber at bargain prices. However, it is illegal to cut trees for firewood from the government forest. Some villagers have planted timber trees in their plots.

Up until 1974, transportation between Kithumba village and other centres was impossible particularly in the rain season when the roads and bridges would be washed away. Transportation between the village and other major centres and services like schools and hospitals or with the capital of Nairobi is now good because the road from Kithumba to Nairobi is tarmacked. It was constructed between 1971-74, a product of a political "armtwisting" of the government by the then local member of parliament. The construction of this road opened up this area to the world beyond the village. The road now has regular public service vehicles, some of which belong to the government.

There is one hospital and two health centres accessible to the people of Kithumba village. Although these centres are not within walking distances from Kithumba, there is adequate means of transport to and from these centres. The hospital, which has a visiting qualified doctor, is run by the Precious Blood Catholic sisters. One health centre is run by a local church and the other by the government. The government run health centre is supposed to offer free medical services to the local people. With the current government cuts on spending on health and social services, this centre is understaffed and lacks basic drugs.

\section{Schooling in Kithumba}

There is no school inside the village but Kilome nursery, primary and harambee secondary schools lie just outside the village. The children of this village go to these various schools located between three and six kilometres from the village. Some children have to walk 
long distances to their schools particularly those in secondary level. None of the girls from this village were attending Precious Blood Girls school at the time of my study.

Kilome secondary school was built by the community in 1979. As an harambee school, it receives minimum assistance from the government. The government posts and pays a few graduate teachers to teach in Kilome harambee secondary school. The school is not well equipped and has not established itself as a reputable school. Accommodation for teachers is a big problem because the school has no teachers' houses in the school compound, as in government-maintained schools. Kilome town itself has very few substandard houses that teachers can let. Most teachers who are posted from the universities to teach at Kilome secondary school never report. They always try to be re-posted to other areas. Other secondary school children from this area who are not admitted to boarding government schools go to other relatively older harambee schools in other divisions. These include Kilungu day (has no boarding facilities) and Mukaa secondary school which has boarding facilities.

\section{Kithumba Women's Self-Help Group}

I went to Kithumba village because when I was growing up in Uvuuni village about five kilometres away, I got to know an elderly well respected woman in this village. I went to the village and informed her of what I was doing and requested her support in gathering women from her community for me. I knew that women from different villages irrespective of their age, social class, clan or church affiliation would respond to her call because of her age and reputation in the community. My first meeting was attended by about 50 women. The meeting lasted for about two and a half hours. As we began to talk about ourselves, I learnt that some of the women had walked long distances to attend this meeting. Some came from 
Kyandue village about eight kilometres away. The discussions that $I$ had with the women in the first meeting, particularly those from Kyandue village, encouraged Kithumba women to form a women's group in their village since no women's self-help group existed in Kithumba village prior to our first meeting.

A few women from Kithumba were members of other women's self-help groups in neighbouring villages. These included Uvuuni Welfare Organization, which has male membership, and Kwa Muulu, which is associated with the GreenBelt movement. The GreenBelt movement encourages environmental awareness and makes tree-planting an income-generating activity for women. Female members of Uvuuni Welfare Organization expressed dissatisfaction with the organization because some members live in Nairobi and have personal projects which took precedence over the organization's ones. The women wanted to have more control over their activities and goals. They noted that every home has a baby girl and it was extremely important to make sure that these girls did not leave school prematurely as their mothers did. The women noted that education provided a sure escape from poverty. They decided to form a new women's self-help group in which they would include education of girls as a major goal.

I spent about two and half months in and out of Kithumba village. During this time, the women formed the Kithumba Women's Group, laid down rules to govern their group and completed several sets of handicrafts. The women agreed that each member should pay Ksh 100 (4 CAD) to become a full member. This money was to be paid over a period of not more than 10 months. In addition to the membership fee, each member had to pay a Ksh 10 registration fee. The women agreed that they would be meeting fortnightly. I became a 
member of this group, attended six meetings and recorded four of them. I also videotaped part of these meetings. In addition, 10 women from this group agreed to talk with me individually. The interview periods ranged from 50 minutes to one and half hours. In two of the interviews, I had to take notes because the tape recorder failed to work. I also talked to four girls, one is in grade 8 and the other three are in the final year of their secondary level education. The girls' mothers were among the 10 women I interviewed from Kithumba women's group.

\section{Kyandue Village}

Kyandue village is also in Kilome Division of Makueni District. It lies eight kilometres east of Kithumba village and south of the divisional headquarters at Kilome. Kyandue village is surrounded by very high hills which isolate this village from other centres particularly in the rain season. It occupies an area of about 15 square kilometres and has a population of about 6500 people. My first meeting with the women of Kilome at Kithumba village was attended by women from Kyandue village. Among them were members of Kyandue women's self-help group. Kyandue women present at the Kithumba meeting had felt that the issues we discussed at Kithumba were of importance to them and it would be important for me to go to their village to meet with more Kyandue women who were unable to attend the first meeting at Kithumba. The women asked me to visit them in their home village, talk with them and see what they do as individuals and as a collective to meet the needs of their children, both boys and girls, and to create educational opportunities for them. 


\section{Life in Kyandue Village}

Each family in Kyandue village has a piece of land where members grow subsistence crops, mainly maize, beans and pigeon peas in the rainy season. Some of the plots yield high harvests, while others have poor harvests. Family plots range from 2.5 to 5 acres. Kyandue is warmer than Kithumba and this accelerates the maturity/ripening of food crops and so, yields are much higher in Kyandue than in Kithumba village. Most of the families own some livestock, the number depending on the size of the family's plot. Those with bigger plots keep cows and goats, but those with smaller plots keep a few goats that are often tethered. A good number of families practice zero grazing where the livestock are fed and given water in the barn. The feed and water have to be fetched by women.

Women in Kyandue village earn income from (a) selling vegetables, onions, bananas, milk and excess farm produce (maize and beans), (b) working as casual labourers, and (c) participating in women's self help groups' income-generating activities. A few women have coffee in their plots. Coffee, the only cash crop planted in this area, belongs to the man as the head of the household and women have no control over the income from it although they are responsible for cultivation, picking, transporting and cleaning the berries at the coffee factory. Women from Kyandue village did not count on income from coffee sales.

Kyandue village has no health centre. The nearest one is about 10 kilometres away and there is no means of transport to this centre. In addition, the centre, like all other government health centres, handles simple ailments but not serious cases. Serious cases are dealt with at Kikoko hospital, 15 kilometres away, or at Machakos general hospital, 90 kilometres away. 
Most people prefer to go to Kikoko hospital, which is run by the Precious Blood Catholic Sisters. This is a private hospital, but charges are subsidized by the Catholic mission.

The major difficulty that the people of Kyandue face is transportation. Kyandue village almost resembles a cone with hilly slopes. One major road runs on its circumference. On one arc the road is all weather and the other arc it is seasonal. There are no major roads running within the village. During the rain seasons, the seasonal roads are so impassable that family and relatives have had to carry their dead in a casket over a distance of three kilometres by hand down the slopes to the village for burial.

\section{Schooling in Kyandue}

Kyandue village has a few nursery and primary schools but no secondary school. There is a harambee secondary school in the neighbouring village about six kilometres away on the hills. This school was opened about 10 years ago. It receives no support from the government. Therefore all the teachers in this school are grade 12 graduates who hold advanced level certificates. In some cases bachelor of arts graduates who fail to find employment in the city offer their services in these schools. Most teachers are temporary and that affects the students' performance in the national examinations. Few students from harambee schools here or elsewhere in the region go to university. Very few students from Kyandue village qualify to go to Precious Blood Girls Secondary School, which is about 15 kilometres away. 


\section{Kyandue Women's Self-Help Group}

Kyandue village has one major women's self-help group which is divided into sections A and $B$. The women noted that there are certain times when it is convenient and necessary to operate as one group, particularly when doing community work such as building gabions ${ }^{3}$ for soil conservation, and other times when they see it necessary to work as separate groups.

Membership in one section of the group is limited to women married to men from the Ambua clan. ${ }^{4}$ This group formalizes marriages of women married to Ambua men by paying bridewealth. The Ambua women's sub-group of the Kyandue women's self-help group was formed out of a crisis when a woman married to a Mumbua man died and a dispute arose over whether the husband could claim her body and children since he had not paid the bridewealth. Other women married in this clan, who traditionally are taken as co-wives, felt that their counterpart was mistreated in death and vowed that they would not permit a repeat of that incident. The widower had to pay bridewealth to his deceased wife's parents so that he could bury her and keep the children they had had together.

The Ambua women's self-help group meets once every week. They bring firewood to one member each week and contribute 10 shillings ( 0.33 Canadian dollars). The money is kept by the treasurer and it is used to buy goats and other gifts which are presented to a bride's parents as bridewealth before marriage. Similarly, the women present gitts to parents of women whose marriages were not formalized. This is in line with Akamba traditions, however, there is no fixed amount that the women have to pay.

\footnotetext{
${ }^{3}$ Gabions are large baskets made of wire mesh and filled with rocks and soil. They are used to help stop soil erosion.

${ }^{4}$ Ambua clan is one of the many clans that make up the Akamba ethnic group. An individual from the Ambua (rainmakers) clan is called a Mumbua.
} 
The combined group, which has 40 members, meets twice a month. The ages vary between $20-60$ years. They pay 10 shillings during each meeting. The women also plant bananas for their members. Each meeting is held at the plot of a member who must have previously prepared 80 holes to plant the bananas. The women use some of the money they contribute to buy bar soap and kerosene. These items are kept at individual members' homes accessible to all members who are expected to buy their own commodities instead of going to the shops. The profit goes to the women's joint account. They also give loans to members and non-members at differential interest rates.

I spent about five weeks in Kyandue village. I did not become a member of this group which was formed a year before I arrived. I attended three of their meetings and tape recorded two of them. Part of the interview with the group members was inaudible. I had to make notes to fill the gaps. In addition, I interviewed 11 members of this group individually and tape recorded all the interviews. I also interviewed a daughter of one of the women who attends an harambee secondary school. The length of the interviews ranged from 50 minutes to one and a half hours.

\section{Salama Town}

Salama is a unique town in Kilome division. It is about 125 kilometres south of Nairobi and about 10 kilometres from Kithumba and Kyandue villages on the NairobiMombasa highway. The Nairobi-Mombasa highway is part of the Trans-African highway. Salama has a population of about 1,000 people. The people come from villages around Salama and from other regions of the country. 
In Salama, I approached a middle-aged woman who was selling tomatoes, potatoes and onions outside a shop. I bought some tomatoes and sat next to her on the bench that she was sitting on and I continued talking with her. I asked her about herself, where she was born and where she was married, if she was, in an attempt to find out if she knew somebody that I knew when I lived in this region. She told me that she was a niece to one woman who was an undersecretary in the government, and who contested the local parliamentary seat in the late 1970s. Although I was young in the 1970s, I had heard about this woman who was well known in this area. This woman was known for her career achievements and courage to enter male-dominated mainstream politics. Her career and political aspirations came to an end when she lost her battle to breast cancer.

Through this "legendary" woman, I found that I knew my new friend's/contact's cousin. I also learnt that my contact's daughter who left school in Form 2 because of school fees, worked as a house girl for this cousin. Once we realized that I knew a couple of women whom she knew and respected, we became quite comfortable with each other, and I was able to talk to her about what I was doing. I asked her whether any of the other women in Salama town would be interested in talking with me about issues related to the education of women. She agreed to contact other Salama women for me. A week later, I went to see her and she told me that some women were willing to come and meet with me, and she gave me the possible days and times that these women would be available.

I spent about two months working with Salama women. We discussed the education of women in general, their own and that of their children, and in particular the education of their daughters. We talked about (a) their education and the barriers that they faced, those 
that their daughters face and their roles in creating educational possibilities for their children and siblings, (b) ways to enhance women's earning opportunities, c) the role and activities of a women's self-help group and the formation of Salama Women Development Group.

\section{Life in Salama}

Salama is a town that attracts girls from the villages who use Salama as a gateway to the city and larger towns. Business in Salama is geared towards providing service to the truckers and also to the local community. The truckers ply between Rwanda, Uganda, Sudan and the port of Mombasa. A good number of the girls work as barmaids in the beer halls and others work in the hotels. The middle aged women, some of whom were once barmaids, run some of the hotel and bar businesses and others are petty traders who sell vegetables, potatoes, tomatoes and onions and others sell miraa-a leafy anti-sleeping stems that are chewed by truck drivers and Somali men. A few of the women are seamstresses.

Salama does not have a good image because of the truckers. The Nairobi-Mombasa highway is considered to be part of the AIDS corridor of Africa. Salama town is associated with "immorality," and women who live and work there are assumed to be promiscuous. Women compose a good proportion of Salama's population and therefore I went to Salama because I wanted these women to share with me their experiences of education and of their life in Salama.

Most of the buildings at Salama are made of cement blocks and roofed with corrugated iron sheets. The front section of the building has a huge room that can be used as a shop, butchery, hotel or a bar. The back of a building are two rows of single rooms facing each other. These rooms are rented out to truck drivers and to the men and women who work in 
Salama. In general, the rooms are too small for a family. The rooms measure about $5 \mathrm{ft}$ by 7 ft. People who live in Salama have no plots to plant food crops.

There is no hospital in Salama. There is, however, a private clinic which provides emergency services. The nearest health centre is about 20 kilometres away and major hospitals can be found in Nairobi and in Machakos. The roads linking Salama to major centres in the country are tarmacked. However, roads linking Salama to the interior have no regular public service vehicles.

\section{Schooling in Salama}

The only school in Salama town is a Madrassa, an Islamic religious school at the mosque. The nearest nursery and primary schools are about 1.5 kilometres from Salama along the highway. There is an harambee secondary school about 5 kilometres away. This school was built by the local community on an harambee basis 12 years ago. None of the girls in Salama go to Precious Blood Girls School.

\section{Salama Women's Self-Help Group}

Up till the time I went to Salama there was no women's group. People living in Salama did not seem to have a strong sense of community as in the villages. However, the women who participated in this study expressed the need to form a women's group so that they could continue meeting when the study was over. I became a full paid-up member of Salama women's self-help group. The women agreed to welcome three men into their group. All the meetings were held under a tree in a space allocated to Salama Jua Kali artisans. Peter,

\footnotetext{
${ }^{5}$ Jua Kali means hot sun. These are open air industries and garages.
} 
who is the coordinator of the artisans in Kilome division, permitted us the use of this space. Peter, who later became a member of this group, had also worked as a coordinator of several women's self-help groups in Machakos town. He claimed an awareness of gender issues and portrayed an understanding of the privilege men have enjoyed in the society. Two of the other men were introduced to the group by their spouses, but their membership had to be negotiated with all the members of the group. The Women's Bureau in the Ministry of Social Services allows a few men to join women's groups on condition that they don't take leadership roles. However, male patronage in women's self-help groups has became an issue of concern. Udvardy (1988) points out that the patron-client relationship found between women's self-help groups and certain males affects the independence and success of women's self-help groups' projects. She argues that male patrons have access to resources that women cannot easily obtain by virtue of their structurally superior status of men and also through the formal local administrative offices they might hold.

The first meeting was attended by seven women and one man. Each member was asked to pay a membership fee of Ksh 140 (\$5) within a week. The membership fee was used to build a shelter and to buy eggs and soft drinks for resale. The progress the group was making attracted more women than the group could admit. The women limited membership in the women's group to 18 . The women agreed that there was a need to come together and begin to address issues that affect them as individuals and as a group. The women identified poverty as a major impediment to their education and that of their children. The group aims at saving money to purchase a maize mill, which would increase their income and enable them to afford to give their children meaningful educational opportunities. 
During my work with the women's group in Salama, it became evident that women living in the town had differences among themselves that limited their interactions. These included (a) type of business and employment, (b) marital status, and (c) age. Women who ran their own or family businesses and were married were more comfortable with each other. Single older businesswomen, most of them who had previously worked as barmaids, also tended to relate together more favourably and younger women, who were currently working as barmaids, felt more comfortable other girls who worked as barmaids. These kinds of groupings seem to have some relation to images that the women of Salama want to portray. It seemed to me that those married business women want to show the world that their business is "clean." This could be a struggle to shape a different image for Salama, which is perceived by people, particularly those living in the villages in the interior, as an immoral town.

The major difference between life in the villages and that in Salama, a transrural town, is the "atomistic" lifestyle that people in Salama seem to lead. One participant pointed out rather regretfully that "people in Salama live as entities and no one cares about what the other does. Each one here does whatever he or she desires. You concentrate on your business, if that is what you do. If it succeeds, it does, if it doesn't, that's it for you. If you need help, maybe your friends will give some help. Otherwise we do not live the way people live in the villages" (Interview, July, 1994).

\section{Participants}

While in Kilome division, I held several meetings in the villages and in Salama town. These meetings were attended by a total of about 120 women. During the initial meetings, I 
introduced myself and requested the women to participate in the study. As summarized in Table \# 1 on participants, thirty women from the villages and transrural town of Salama volunteered to talk with me individually about their experiences of education, that of their children and about their day to day experiences. In addition, three professional women, born and partly schooled in Kilome division but now living in Nairobi, and five high school girls in Kithumba and Kyandue villages agreed to participate in this study. The high school girls' mothers were among the women in the villages who participated in the study. I found out about these girls during the interviews with their mothers and requested that their mothers ask them if they would be willing to talk with me. The girls were all students in senior primary and secondary schools in the Kilome division. All the participants are identified by pseudonyms.

The ages of the rural women and those living in Salama who volunteered to participate in this study ranged from 19 to 75 years. Initially, I had planned to interview women whose ages ranged from 20 to 45 years. However, I interviewed/talked with three women whose ages were over that bracket (aged 50,70 and 75 years old respectively) because they were members of the women's self-help groups I was working with and it would have been impolite to turn them away and fail to listen to their experiences, which were set within a different time space of Kenyan society. These women, too, were respected in the community and because of their age and wisdom, held positions of responsibility in the women's self-help groups. As Ahlberg-Maina (1991) notes, older women continue to hold positions of power in the women's self-help groups even though they might be illiterate. The older women's experiences are important to this study because their views give a picture of how cultural assumptions about women's roles have changed over a relatively short period of time. 
The ages of the three professional women ranged between 35 and 38 years. ${ }^{6}$ The professional women are the role models rural women would like their daughters to become. Some rural women idealize education as a panacea to the social and economic difficulties that women face. However, the professional women's stories/experiences attest to the fact that women's educational and economic inequities do not disappear with good education.

The level of education of the women who participated in this study ranged from 0 to $18+$ years of formal schooling. The professionals have the highest number of years of formal education. They have had at least 12 years of formal education followed by two or more training in a tertiary institution. All the professional women I talked to lived and worked in Nairobi although they grew up in Kilome division.

All the women participated in my study knowing that whatever they said to me was confidential. I, also, promised them that I would use pseudonyms to protect their identity.

\footnotetext{
${ }^{6}$ I had known these women when I lived in Kilome division. However, I obtained their current contact addresses from their families who are still living in Kilome division.
} 
Table 1. Participants: A summary

(I have used Pseudonyms)

\begin{tabular}{|c|c|c|c|c|c|c|c|c|}
\hline \multirow[t]{2}{*}{ Name } & \multirow{2}{*}{$\begin{array}{l}\text { Years of } \\
\text { formal } \\
\text { education }\end{array}$} & \multirow[t]{2}{*}{ Village } & \multirow[t]{2}{*}{ Age } & \multirow{2}{*}{$\begin{array}{l}\text { No. of } \\
\text { children }\end{array}$} & \multicolumn{3}{|c|}{ Marital Status } & \multirow[b]{2}{*}{ Single } \\
\hline & & & & & Married & Separated & Widowed & \\
\hline Mwelu & 4 & Kithumba & 40 & 7 & $\sqrt{ }$ & & & \\
\hline Mumo & 4 & Kithumba & 75 & 7 & $\sqrt{ }$ & & & \\
\hline Mulee & 7 & Kithumba & 44 & 8 & $\sqrt{ }$ & & & \\
\hline Mwikali & 3 & “ & 54 & 7 & $\sqrt{ }$ & & & \\
\hline Catherine & 7 & “ & 37 & 5 & $\sqrt{ }$ & & & \\
\hline Kanini & 4 & " & 46 & 7 & & & $\sqrt{ }$ & \\
\hline Maria & 13 & " & 30 & 3 & & $\sqrt{ }$ & & \\
\hline Rose & 9 & Kithumba & 36 & 10 & $\sqrt{ }$ & & & \\
\hline Wayua & 0 & " & 46 & 8 & & & $\sqrt{ }$ & \\
\hline Mutinda & 7 & Kithumba & 30 & 5 & & $\sqrt{ }$ & & \\
\hline Teresia & 1 & Kithumba & 50 & 10 & $\sqrt{ }$ & & & \\
\hline Wanza & 7 & Kithumba & 34 & 7 & $\sqrt{ }$ & & & \\
\hline Janet & 9 & Kyandue & 33 & 5 & $\sqrt{1}$ & & & \\
\hline Ruth & 7 & Kyandue & 45 & 7 & $\sqrt{ }$ & & & \\
\hline Ndunge & 7 & “ & & 7 & $\sqrt{ }$ & & & \\
\hline Ndele & 6 & Kyandue & 36 & 5 & $\sqrt{1}$ & & & \\
\hline Ngina & 3 & Kyandue & 42 & 8 & $\sqrt{ }$ & & & \\
\hline Rachel & 7 & Kyandue & 39 & 5 & $\sqrt{ }$ & & & \\
\hline Meli & 1 & Kyandue & 45 & 7 & & & $\sqrt{ }$ & \\
\hline Faith* & 11 & Kyandue* & 32 & 5 & $\sqrt{*}$ & & & \\
\hline Katunge & 11 & " & 36 & 3 & $\sqrt{ }$ & & & \\
\hline Nzula & 9 & Kyandue & 38 & 4 & $\sqrt{ }$ & & & \\
\hline Mariya & 7 & Kyandue & 42 & 10 & $\sqrt{ }$ & & & \\
\hline Kavuli & 7 & Kyandue & 28 & 4 & $\sqrt{ }$ & & & \\
\hline Kasika & 0 & Kyandue & 38 & 8 & & & $\sqrt{ }$ & \\
\hline Kadogo & 7 & Kyandue & 33 & 3 & & & & $\sqrt{ }$ \\
\hline Nzeli & 4 & Kyandue & 70 & 7 & $\sqrt{ }$ & & & \\
\hline Beth & 9 & Salama & & 8 & $\sqrt{ }$ & & & \\
\hline Mbeti & 7 & Salama & 35 & 0 & & & & $\sqrt{ }$ \\
\hline Kamene & 3 & Salama & 37 & 4 & & & & $\sqrt{ }$ \\
\hline Wanza & 3 & Salama & 33 & 1 & & & & $\sqrt{ }$ \\
\hline Kambua & 8 & Salama & 19 & 0 & & & & $\sqrt{ }$ \\
\hline Nduki & 7 & Salama & 35 & 2 & & & & $\sqrt{ }$ \\
\hline Wausi (P) & $18+$ & & 35 & 1 & & & & $\sqrt{1}$ \\
\hline Mutheu (P) & 17 & & 38 & 3 & $\sqrt{ }$ & & & \\
\hline Koki (P) & 16 & & 35 & 1 & & & & $\sqrt{ }$ \\
\hline Ndinda(S) & 11 & & 17 & 0 & & & & $\sqrt{ }$ \\
\hline Jane (S) & 12 & & 17 & 0 & & & & $\sqrt{1}$ \\
\hline Munee(s) & 12 & & 18 & 0 & & & & $\sqrt{ }$ \\
\hline Waeni(s) & 12 & & 18 & 0 & & & & $\sqrt{1}$ \\
\hline Mueni (s) & 9 & & 15 & 0 & & & & $\sqrt{1}$ \\
\hline
\end{tabular}

-The latest information I have from Kithumba and Kyandue womea is that Faith has movod back to her father's house leaving her five children behind. She is a member of a women's group that gives assistance to children of "runaway" mothers.

Key: P= Professional, $\mathbf{S}=$ Studen: 


\section{Interviewing}

The major data collection strategy in the field were semi-structured open ended interviews. As Reinharz (1991) points out, open-ended interview research makes it possible to explore people's views of reality from which theory may be generated. With the women in rural areas and in Salama, I conducted the interviews in the local dialect of Kikamba, a variant of Bantu language. I used a mixture of Kikamba, Swahili and English with the professional women. ${ }^{7}$ Holding interviews in a mixture of the three languages was an advantage because there are certain words that attain their full meanings, strength and flavour only if expressed in vernacular. Being a Mukamba and one who grew up in this area, $I$ had an added advantage in that I could understand the proverbs and idioms that the women used as well as the nuances that characterised the women's way of talking. Laughter among Kamba women is a communicative tool. There are certain ways that women can laugh to imply, for example, "subversiveness" on their part or in whatever you are suggesting to them. It would be difficult for one who did not grow up in the village to understand these nuances.

I conducted 38 interviews with individual women from Kilome Division. The interviews ranged from between 50 minutes and one and a half hours. I audio-taped the interviews and wrote field notes. I preferred to write the notes after each interview because I found that the constant "burying" of my face to write something and then looking up to talk with the women disturbed the flow of the story. I felt that the women would feel that I was more interested in getting information from them for my personal good than in listening to

\footnotetext{
${ }^{7}$ It is common for schooled people to mix their vernacular with English or Swahili.
} 
them. I relied on my audio-tape and only wrote brief comments on peculiar body language that the woman used.

\section{Interview/Discussion Topics}

Discussions were centred around the following issues, but during the discussions women brought in issues that were of importance to them that were not necessarily related to these topics.

1. Education. We discussed the education of girls in Kilome division the education of their children and their own education in that order. It would have been impolite for me as an educated woman to begin by asking them what level of education they acquired because this would set up a situation of comparing educational achievements. We discussed the barriers to girls' education in Kilome division, availability of support for girls (government aid) and ways through which girls could be supported to achieve educational, employment/and income-generating skills. We discussed the women's role in creating educational opportunities for their children and daughters in particular and their visions for their children and girls in particular.

2. Paid and unpaid work. We discussed the kind of work that women do. This includes: (a) employment, (b) agricultural subsistence work for the provision of food for the family, (c) involvement in income-generating activities, and (d) possibilities and constraints that they face in their participation in income-generating activities.

3. Family and sexuality. We discussed issues pertaining to the family and what it means to be either a wife, mother, sister or daughter. We talked about their spouses and where they live and what they do. We talked about children and the number of children that they have. 
4. Women's self-help groups. We talked about the women's participation in women's group and what they do, the purpose, and advantages of these groups.

In my discussion, I tried as much as possible to avoid my specific agenda so that the women could become freer to tell their stories as fully, completely, and honestly as they desired (Anderson \& Jack, 1991).

\section{Translation of Interviews}

In order to complete this study, I had to translate the interviews from Kikamba to English. Aware that advantages of interviewing in vernacular would be compromised during translations, I tried to get clarifications from the women of the specific meaning of words that they used that I felt would be hard to translate into English. Asking the women questions like "what do you mean by that?" "Please explain further" helped me during my translation of the interviews from Kikamba into English. Since language is dynamic, it was important for me to seek elaboration on words and phrases that were not familiar to me because Kikamba language is laden with metaphors that can be altered to suit specific situations.

During the translations of the interviews and writing of this ethnography, I have continued to examine my first translations seeking ways of improving them. I have sought my husband's knowledge of Kikamba and compared my interpretations of certain words and phrases with his own. His assistance has helped me to represent the women's voices as accurately as possible given my limitations and including the fact English is my third language after Swahili! 


\section{Writing Ethnography}

Culture is not itself visible but is made visible through its representation. Ethnography, the result of fieldwork, is the written report that represents the culture. Writing ethnographies is not unproblematic (Van Maanen, 1988). Gluck and Patai point out, moreover, that "women interviewing women is not an unproblematic activity either. Taping a woman's words, asking appropriate questions, laughing at the right moment, displaying empathy-these are not enough" (1991, p.9). Anderson and Jack (1991) argue that for women interviewers to hear women's perspectives accurately,

we have to learn to listen in stereo, receiving both the dominant and muted channels clearly and tuning into them carefully to understand the relationship between them ... search for stories that lie beyond constraints of acceptable discussion to the experience that lies outside the boundaries of acceptability. (p.11)

Stacey (1991) argues that there is dissonance between fieldwork practice and the ethnographic product. She argues that, "despite the fact that ethnographic methods place the researcher and the informants in a collaborative, reciprocal quest for understanding, the research product is ultimately that of the researcher, however modified or influenced it may be by informants" (p. 114). Even though representing others is problematic, representation of others still remains crucial in the struggle for political and cultural empowerment for those groups who have remained silenced, due to specific material, intellectual and social circumstances (Salazar, 1991).

I am conscious of the contradictions of writing an ethnography of the women of Kilome. On one hand lies the potential for exploitation and on the other hand is the crucial role this ethnography contributes to understanding gender relations in African societies, specifically making visible women's agency in the midst of harsh economic, social and political 
contexts. Writing an ethnography of Kilome women is important to make their agency beyond motherhood visible. Consequently, Kilome women's discourses on education are "constructed" from interviews that I held with them as individuals and as a group. The discourses are constructed by putting gender at the centre of the women's experiences. "Feminists researchers see gender as a basic organizing principle which profoundly shapes and/or mediates the concrete conditions of our lives" (Lather, 1991, p.17). The women's experiences are structured by gendered assumptions within different historical, cultural, economic and political contexts of Kenya society. The ethnography I am writing is influenced by what Lather (1991) calls postpositivists' emancipatory approaches to inquiry with feminist approaches playing a major role. I am indeed "tempted" to call this work feminist ethnography (Stacey, 1991; Reinharz, 1992).

\section{Reflections on Doing Research in Kilome Division}

Scheurich (in press) argues that, "contrary to the fact that many, widely differing kinds of validity have been delineated across a burgeoning array of research paradigms, the myriad kinds of validity are simply masks that conceal a profound and disturbing sameness" (p. 1). He notes that validity wears different epistemological masks and he concludes that validity as a practice across both conventional and postpositivist paradigms is a civilization project, a bifurcation reinscribing dominance of the Same over the Other. He advocates for "the validity of voice which does not prevent the innumerable voices of difference from participating equitably in the conversations of kuman kinds which is based on the fact that the researcher is researching those from her or his own social location" (p.19). 
My fieldwork took me back to the village where I was born and raised. Reflecting on my entry into the research field I realize that I had to begin to think and act like one of the women of Kilome, a Mkamba woman, the ethnic group to which these women and I belong. I had to re-leam how to create the atmosphere in which women could become comfortable to tell their stories. This involved abandoning the linear method of inquiry.

When women meet they must share some food or a cup of tea. It is the Akamba belief that a host does not ask for a story (or questions) of their guest before he or she feeds them. I could not begin to ask women to tell me about their experiences of education before I had prepared the conditions for sharing experiences. For this reason I had to make tea and prepare food for the more than 120 women who met with me at various times during the fieldwork. After eating and drinking, I spoke with the women about the research, what I was doing and requested their participation.

I learnt from the women that I could not maintain a sequence of discussing their educational experiences. For instance, it became clear that women were not preoccupied with why they left school. It was obvious that they had left school, but their major interest was to begin talking about possibilities-their agency and using the past to inform the present. The women gave me the message that they are living in the present and not in the past.

\section{Barriers and Dilemmas}

My age and education, at times, became barriers that had to be overcome for the women to tell their stories. For example, there were silences/gaps when I introduced the topic of sexuality. I attributed this silence to the fact that sexuality is seen as a taboo topic that should be handled in private. Traditionally, issues relating to sexuality were addressed during 
circumcision period which involved youngsters of a specific age group. Our group discussions involved women of various ages. During these discussions, the young women did not feel free to discuss sexuality in the presence of the older women. Older women seemed to have fewer difficulties talking about their sexuality. This is not surprising because, culturally, it was the older women, particularly grandmothers, who discussed with granddaughters aspects of female sexuality.

Being partly an insider and relatively young was also a dilemma. The older women maintained the image of me as a child, they kept their image of me "frozen" in the past. This perception of me as a child provides explanation for the times when there would be prolonged silence from the women. I was able to diffuse their "frozen" image of me by invoking our shared experiences particularly motherhood and wifehood. My children's presence reminded them that I was no longer a child. Often, I asked the oldest women to share with us how they have handled men. I suggested that it was important for us young women to hear how our mothers worked their way around patriarchy. I stressed the commonality between the women and myself to gain their trust. I was particularly amazed at how older women have used sexuality to get their husbands' attention. These proved to be important ways of breaking the silence.

Although there were benefits of being a local "girl," there were also special tensions that arose as a result of this factor. My work with the women was seen as an interest in politics. The local member of parliament and his stalwarts could not believe that my research was not a cover-up for soliciting votes. Because rural people have the votes, politicians in Kenya are concerned when those they perceive as potential competitors, professionals, 
establish a relationship with the people at the grassroots level. My actions were interpreted as a preparation for the 1997 parliamentary elections. This rumour culminated in the visit to one of the women's self-help group's meeting by a man from the Criminal Investigation Department (C.I.D.). He was interested in knowing why the women met and if their meetings were authorized. The visit enraged the women and they categorically refused to be harassed and intimidated by him. An older woman, a petty trader, confronted the special branch officer and stressed to him that women organizing was not a new phenomenon and indeed their group had authority to meet. She insisted that his visit was designed to intimidate women so that the women's self-help group would collapse. She had the support of all the other women. The women challenged the man to sit down and listen to issues they were discussing. He could not take the challenge and he excused himself and left.

Rumours of what would be done to women who were found holding political gatherings under the guise of women's self-help group did intimidate some women. Indeed some of the women were "forced" to re-evaluate their membership in the women's group. Some women stopped attending the meetings as a result of the visit by the C.I.D. official as they feared what would happen to them if they were arrested. A week later the chairperson of this group was called to Kilome, the divisional headquarters of the Office of the President, to explain the purpose of the group. She found the special branch man, who accused her of being a leader of a gang of women who do not know how to speak to menl This was because the man was challenged by women, which is an unacceptable reaction in a genderstratified society. 
The local MP, who has grade six education, certainly felt that if I declared my interest in his constituency, I would have a large following since he had not lived up to his campaign promises and he was not making any effort to reach the people at the grassroots level who voted him into parliament. The fact that I was working closely with the women was a threat to him as he did not have a similar relationship with his electorate, the majority of whom are women since so many men work away from the area. My attempts to bridge the gap between myself as an educated person and a woman with women in the grassroots level were construed as political and subversive. Demystification of power relations between researchers and researched and social change are some of the aims of feminist research.

In conclusion, working with the women of Kilome division I became aware of the exclusion of rural women's concerns and needs from the public discourses on education and development that affect their lives and those of their children. For example, women had no access to information on how to access government support for their children's education or to get credit to improve their income-generating activities. As time passed and the women's list of required information grew, I began to understand why one woman had said to me "maybe you are an angel sent to help us penetrate this labyrinth."

In summary, the study aimed at supporting women to speak about their experiences and identify issues/factors that limited their participation in education, employment and in other social activities and how these factors have shaped and continue to shape their daily experiences. It aimed at empowering the women and demystifying the power relations invariably involved in research. The study also aimed at supporting women in their struggle to change/shape social conditions that delineate their lives and to create and 
and/or revive wider networks of support. The study employed research methodology that made visible women's agency as social actors who formulate strategies for influencing and shaping the social system of which they are a part. 


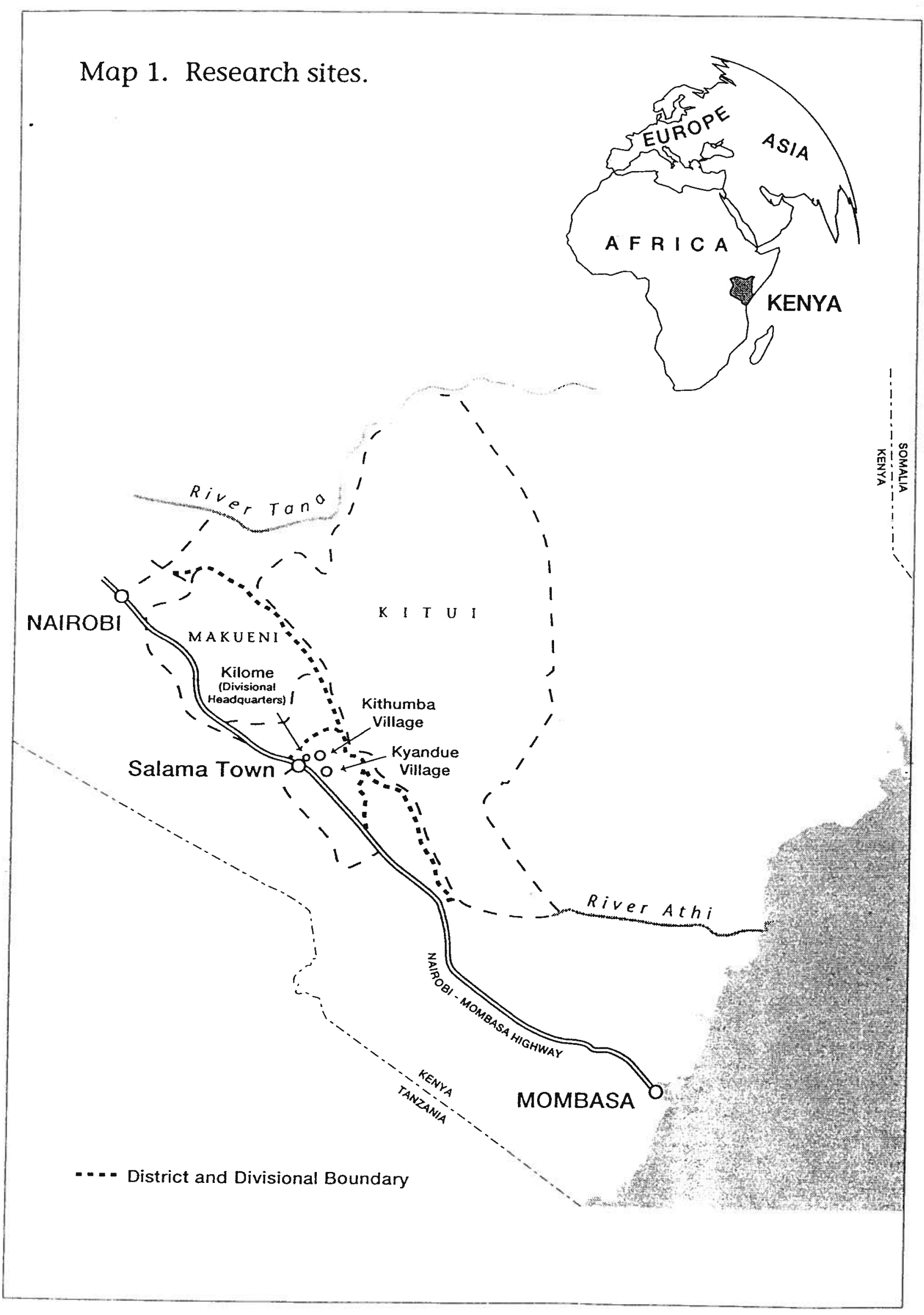




\section{Chapter Four}

\section{Analysis of Education and Development Policy Documents}

It is 10:30 am and bell rings to mark the end of the first session of the school day. Kids dash out of classes like winged termites after a heavy downpour. A group of girls are jumping a sisal rope, another group of boys are playing with a ball made from sisal pith. Close by is another group of girls, 8-10 yeas old.

They are singing, singing a "mature" song.

Niw'aa nanonie nditinda ndilumangwa, ningusyoka kwitu ngatwawe mula ngwenda ninguvoya Ngai ni syae twana twili Kala ka kavisi ndiketa Tom Mboya Kala ka kelitu ni Ngina wa Kenyatta

or

I have taken enough beatings

I will go back to my home and get married to a man of my choice

I will pray God to give me two children

I will call the boy Tom Mboya

I will call the girl Ngina Kenyatta

What does this song have to do with policy? Who was Tom Mboya and who was Ngina Kenyatta? Why would children from the Kamba ethnic group in Ukambani, the region where I did my fieldwork, want to name their children after these two people from the Luo and Kikuyu ethnic groups? Why would they break their Kamba naming customs and name their children after some man and woman from a different ethnic group? What did Tom Mboya and Ngina Kenyatta symbolize?

Tom Mboya symbolized a model politician, freedom fighter, and an elite policy maker. Tom Mboya was the first Minister for Economic Planning and Development in independent Kenya. Tom Mboya was a nationalist, his popularity transversing the 46 
ethnic groups of Kenya. His popularity was perceived as a threat to the presidency of Mzee Jomo Kenyatta, the first president of independent Kenya. Mboya was assassinated in 1969.

Ngina Kenyatta, the wife of Mzee Jomo Kenyatta, was referred to as the mother of the nation- Mama (mother) Ngina Kenyatta. She was the president's third wife, a "gift" to him from the Kikuyu, the president's ethnic group. She was young and he was old. The president's ability to father children at his advanced age was a source of pride for the old man and one he boasted of when he addressed the nation during national holidays.

Three decades after independence, policy making is still predominantly a male preserve. The public discourse regarding the purpose of education of women and men in Kenya is set out predominantly by male politicians and policy makers. Most women continue with their reproductive and productive roles in the private sphere as mothers, wives, daughters, sisters, caregivers, petty traders. These women's work go unnoticed and their concerns remain invisible.

After a brief historical overview, I will analyze Kenya government educational policy recommendations reports which represent the public or official discourse on education in Kenya. I examine the official discourse on education as a state apparatus (Dale, 1989) set within the development discourse of Kenya and its impact on the education of women in Kenya.

Education assumes a central role in development plans in Kenya as in many other countries. Peatie (1981), upon reviewing the history of development planning since the mid-twentieth century concluded that "the planning of education has been placed squarely 
and legitimately into development planning" (quoted in Thomas, 1992, p. 17). Government-initiated development plans in Kenya are influenced by international development agencies such as the World Bank and the International Monetary Fund (IMF) whose operations are perceived as far from being politically neutral by most members of less developing countries (Brett, 1983). The education portion of national development plans typically assigns to the education system roles and responsibilities that will contribute to the national development goals and suggests ways that the system should be improved so that the roles may be performed more efficiently (Thomas, 1992).

Unlike in the colonial times before independence in 1963, Kenyan policy makers have had the opportunity to formulate policies to enhance social, economic and political development of their country. Under colonial power, the people of Kenya had no voice in government; the nation's natural resources were organized and developed mainly for the benefit of non-Africans; and the nation's human resources remained largely uneducated, untrained, inexperienced and deprived of the economic benefits of their labour (Wanjigi, 1983).

As Freire (1985) argues, education is not a neutral enterprise, it is political throughout. The colonial government had used education to enhance and maintain a racially segregated society. They had used education to regulate access to economic, political and social opportunities, consequently limiting Africans to occupations of a rural, semi-tribal society and to the lowest levels of the public administration (Ominde, 1964).

At independence, education became an arm of the Kenya nation--a new notion within which, as the new leaders claimed, all people had equal rights. Education was 
pressed into service to help to foster the psychological basis of nationhood, promote national unity and serve as an instrument for the conscious change of attitudes. Leaders in independent Kenya had been witnesses to the power of education in the control of social, economic and political opportunities during the colonial period. Consequently, the government assumed central responsibility for education at all levels by removing responsibility from various communal and religious bodies who managed the segregated system (Gachathi, 1976).

Since independence, the government's control of education has been enshrined in the Laws of Kenya under the Education Act. This Act entrusts the Minister of Education with the responsibility of promoting the education of "the people of Kenya and the progressive development of institutions devoted to the promotion of education" (Laws of Kenya: The Education Act 1980, p. 5). The Minister is also "in charge of securing the effective co-operation, under his [sic] general direction or control, of all public bodies concerned with education in carrying out the national policy for education" (p.5). The Education Act "allows the Minister to order or entrust any of his [sic] functions with respect to education to a local authority on such terms, conditions or restrictions he[sic] think fit" (Laws of Kenya: The Education Act 1980, p.6).

Involvement of the public is sought during the formulation of educational policy recommendations. Often educators, parents, community leaders and the general public are invited for interviews and their submissions are welcomed. Consequently, the "unofficial" voices are given an opportunity to contribute to the national discourse on education. 
Whether their views have any impact on the educational guidelines that result from these commissions is another issue.

I examine briefly the following government-initiated educational and development reports that have been produced over the last 30 years: Ominde Report (1964), Sessional Paper \# 10 of 1965, Gachathi Report (1976), Mackay Report (1981), Wanjigi Report (1983), Kamunge Report (1988) and Ndegwa Report (1991). These reports give a picture of the pattern of changes in educational policies in Kenya since independence in 1963 to the present. The policies have been used as guidelines in the formulation of relevant curricula. Downey (1988) argues that "policy is an instrument of governance and policy making involves the processing of needs and demands of society as well as establishing of guidelines for the functioning of the system" (p. 23).

The Ominde Report (1964) was the first educational document for independent Kenya. Ominde educational policy recommendations set the path for formal Western education in independent Kenya. New educational policies were recommended to press education into the service of Africans/Kenyans and afford them academic educational opportunities denied them in the previous colonial African education system. The Gachathi Report (1976) examined the impact of the educational policies implemented at independence on national development. The Mackay Report (1981) was the third major educational policy recommendation report. It examined the education system with a specific mandate of laying policy directions for the establishment of a second university after Nairobi University. Closely following the Mackay Report was the Wanjigi Report (1983) which examined education's role in the quest for solutions to the unemployment 
problem in Kenya. The Wanjigi Report endorsed the Mackay Report's recommendations of re-structuring the entire education system as a strategy for combating unemployment. The Kamunge Report (1988) reviewed national education and training for the next decade and beyond. The latest policy document, the Ndegwa Report (1991), addressed unemployment in Kenya, both in the short and long term.

Along with the education documents, I will also examine the following. Sessional Paper Number 10 of 1965 derived from the Kenya African National Union (KANU) ${ }^{1}$ Manifesto (1963), is important to include because it adopted and entrenched colonial (European) concepts of individualism exemplified in individual male property ownership. Property ownership and specifically land ownership vests in individuals the power to enter into social relations on the basis and extent of their property (Dale, 1989). As education has become central to national development plans, I will also look at the education sections in the 1974-78 and 1989-93 development plans.

I analyze the policy documents in light of the political, social and economic rhetoric of the time. The analysis involves examining the public discourse in relation to the following: (a) The role of education in national development, (b) women's education including access and barriers, (c) women and the economy, and (d) women and the family.

I examine the public discourse on education for the rationale for providing women with educational opportunities. I am interested in finding out whether there has been a commitment to providing women with educational opportunities equal to those of their male counterparts or whether educational opportunities for women have been merely part of improving delivery of services as mothers and/or wives in the private sphere. This

\footnotetext{
'The ruling party since independence in 1963.
} 
examination makes visible the gendered and cultural assumptions of femininity and masculinity legitimated at the public national level. In conclusion, I examine the shifting policy themes and the treatment of gender in the policy documents since independence. I examine the policy documents chronologically beginning with the Ominde Report of 1964 .

\section{Ominde Report (1964)}

The Ominde Report of 1964 was produced by the Kenya Education Commission which was initiated by the President of Kenya, a week after independence, on December 19, 1963. The Kenya Education Commission was composed of 14 members, 13 men and 1 woman, all of whom were appointed by the Minister of Education. The Commission was chaired by Professor Simeon H. Ominde, one of the few Africans to hold academic credentials at the time. Four commissioners were members of parliament, others were high ranking civil servants, and some were academics. The sole female member was not an academic or a politician. She participated in the panel that examined primary level education.

The Commission had the task of formulating policies on education to serve the new Kenyan nation. Previous colonial policies dealt with education as separate social activities along racial lines as European education, Asian education and African education. Africans were given an education deemed suitable to their position in colonial life and "appropriate" to the African population, the lowest echelons of the society. Colonial policy on the education of Africans ensured that most of the African population had little or no education. 
Members of the public were invited to present written and oral submissions to the commission. This invitation gave educators, critics and other members of the public an opportunity to express their views. Although the commissioners claimed that their net was flung widely and they sought, and obtained, a great deal of information about the thinking of people in all parts of the country on educational problems, the final policy recommendations were their sole responsibility. Important to this study are the policy recommendations in respect to (a) education and national development, (b) participation of women in educational and economic activities, and (c) domestic labour.

The Ominde Report noted the crucial role education had to play in the cultural, social, economic and political development of the newly-found nation of Kenya. Kenya was in a period of multiple transitions from a subsistence to a monetary economy, from development of natural and human resources for others to the development of these resources for the benefit of Kenya (Ominde, 1964). The Report noted that a highly skilled African labour force was required not only to take up positions that had previously been occupied by Europeans and Asians but also to meet the nation's economic development. The Ominde Report recommended provision of universal basic education and production of high level African skilled human resource for cultural, economic and political reasons. Education in newly-found Kenya was set to (a) foster a sense of nationhood and national unity, (b) serve all Kenyans without discrimination, (c) promote social equality and remove divisions of race, tribe and religion, (d) respect the cultural traditions of the peoples of Kenya, both as expressed in social institutions and relationships (Ominde, 1964, p. 25, emphasis added). Consequently, the education system was placed into the service 
of achieving the social, cultural, economic and political goals of a newly-independent nation.

At the eve of independence, women were underrepresented in education in Kenya since education was developed by the colonial administrators along gender and racial lines. The Ominde Report rejected appeals for girls only boarding primary schools. Advocates of girls only boarding primary schools had argued that "in mixed schools their [girls'] interests are neglected, that they are used by teachers for the performance of duties unrelated to the classroom, and even that there are moral dangers in mixed education at the upper primary age" (p.65). The Report argued that providing boarding primary schools for girls only would not only be expensive but would not necessarily solve the problems identified by proponents of single-sex schools. The commissioners argued that a progressive educational policy for the promotion of good relations and mutual respect between the sexes clearly required that boys and girls be educated together in the same schools at the primary level. The Report, however, recommended single-sex secondary schools as requested by a large number of heads of schools who made oral submissions to the commission.

The Ominde report noted that the need to Kenyanize or Africanize the entire infrastructure of the modern work force, particularly management positions, demanded quick production of highly skilled African manpower [sic] from a pool of uneducated Africans. "The African majority, under colonial rule, had been left with educational prospects which, despite popular pressure, were limited by sheer numbers, by the modest 
means placed at their disposal and by the social and occupational role to which they were restricted" (Ominde, 1964, p. 21).

In summary, the commissioners did not seek to replace the colonial education offered in Kenya prior to independence. Rather, they sought to change the rules that regulated the educational opportunities to favour the "African-Kenya." The category of race eclipsed other forms of inequalities that were part of the inherited colonial system of education and governance. Policy recommendations zeroed in on race issues such as the Africanization of the modern sector. The commissioners emphasized meeting the educational needs of the "African." Subtly, the education system after independence negated the existence of gender barriers in access to educational opportunities and employment opportunities. In addition, the Ominde Report emphasized academic education as a prerequisite for participation in the formal/modern employment sector, and emphasized the modern sector which is urban based. This approach accelerated the ruralurban migration of mostly male job seekers.

\section{Sessional Paper \# 10 : African Socialism (1965)}

The Sessional Paper \# 10: African Socialism and its Application to Planning policy document was produced in 1965, approximately 18 months after independence. It was an in-depth elaboration of the principles of the Democratic African Socialist State as per declarations in the KANU Manifesto of 1963. The KANU Manifesto was a set of declarations that were adopted by the government of Kenya at independence, to provide guidance in its approach to social, economic and political developmental matters. 
The Sessional Paper emphasized rapid economic growth as the guiding principle upon which all policies in independent Kenya would be made and implemented. Rapid economic growth was seen as a solution to the social, economic and political difficulties that Kenya was facing. In this Paper, the government noted that a highly skilled human resource and new property laws were necessary to enhance economic development.

Education was seen as much, or more, of an economic than a social service. It was a principal means for relieving the shortage of domestic skilled workforce and equalizing economic opportunities among all citizens and the acceleration of Africanization. Production of high skilled human resource was seen as a major factor to enhance economic growth. The government warned that free education could not be provided at the expense of economic growth. It also warned that no individual or group would be permitted to exert undue influence on policies of the State. It was made clear that "the State, was never to become the tool of special interests, catering to the desires of a minority at the expense of the needs of the majority" (Sessional Paper \# 10, 1965, p.3).

The government argued that Kenya was in a transition from a subsistence economy to a monetary economy and needed to mobilize resources to attain a rapid rate of economic growth. This economic mobilization and reorganization of resources needed planning, direction, control and cooperation. It was pointed out that:

Kenya is in a period of multiple transition set in motion by the attainment of Independence. We are in transition from a subsistence to a monetary economy, from an economic dependence on agriculture to a more balanced growth, from a development of natural resources for others to a development of human and natural resources for the benefit of the people of Kenya. (Sessional Paper \# 10, 1965, p.1 emphasis added) 
Selected language was used to make Kenyans feel that the changes made were for their good-development of human and natural resources for the benefit of the people of Kenya. Ensuing policies, particularly those that dealt with property (land) ownership and government's perceptions of equity issues, denied women social, economic and political rights.

In pre-colonial Kenya, land was essentially communally or tribally owned. In the colonial period, land registration policy was introduced. This policy was reinforced in post-colonial Kenya. During this time, Kenyans were warned that traditional attitudes towards rights to land would not be carried over to a modern, monetary economy. It was pointed out that "a credit economy rests heavily on a system of land titles and registration and, ownership of land must, therefore, be made more definite and explicit if land consolidation and development are to be fully successful" (Sessional Paper Number 10, 1965, pp.10-11). The "new" meanings of ownership, adopted from the colonialists, emphasized the individual rather than shared/communal ownership and encouraged and facilitated the transfer of property from the community to individuals. Consequently, land was registered under the name of the head of the household or a male relative. This greatly limited women's access to land. The issuance of land title deeds to men as heads of households gave, and still gives men absolute control over the use of the land including the disposal of the land against the will of the wife and children.

The Paper also repudiated the existence of classism in Kenya. It claimed that the sharp class divisions that existed in Europe had no parallel in African society and no place 
in "African Socialism," which was the public political perspective at that time. The document stated that no class problem arose in the traditional African society and none exists today among African" (Sessional Paper \# 10, 1965). The Paper did not discuss gender issues. However, the recommended policy directions impacted men and women differently.

\section{4-78 Development Plan}

The 1974-78 Development Plan defined the economic, social and political context within which the Gachathi Report was realized in 1976. The Plan gave the directions and limits within which policy recommendations were to be made so that national needs were not jeopardized. Economic development was the central theme of this development plan.

Ten years after independence, the country had failed to attain rapid economic growth due to external and internal factors. Internally, there was a political crisis as leaders questioned the interpretations of "African Socialism" by the president of Kenya. Such leaders included Ja Ramogi Oginga Odinga who had resigned his position as the country's vice president because he felt that the ideals of "African Socialism" had been violated and replaced with those of Western capitalism. Kenya also had to address the challenges of high unemployment rate, an education and economic system that promoted rural-urban migration, high population growth and high costs of educating Kenyans particularly at higher levels of education. Educational changes had to be instituted not only to cope with the sluggish economy but to stimulate its growth. These included (a)

\footnotetext{
${ }^{2}$ The term African Socialism was used to describe an African political and economic system that is "positively African not being imported from any country or being a blueprint of any foreign ideology but capable of incorporating useful and compatible techniques from whatever source" (Sessional Paper \# 10, 1965, pp. 2-3).
} 
curriculum changes from an emphasis on academic to vocational education, and (b) reduction of government spending on education and the introduction of the cost-sharing strategy. As Dale (1989) argues, demands for education to become more economically relevant become louder when the economy is doing badly (p. 95).

The Plan recommended the introduction of applied subjects into secondary schools in an effort to provide school-leavers with skills needed by the Kenya economy. Vocational education was seen as capable of solving the unemployment problem by providing school-leavers with the necessary skills needed in industry and also needed skills for self-employment. Vocational education was seen as capable of curbing the rural-urban migration by creating jobs in rural areas and making rural areas more attractive places to live and work. Nevertheless, the vocational education offered was limited by lack of physical facilities (workshops and equipment) and by areas of concentration. The offered courses were wood work, masonry, carpentry and tailoring. These were gender-specific, giving boys more opportunities than girls. The potential for self-employment was further curtailed by lack of resources to purchase tools and equipment.

Recommendations were made in the Development Plan to introduce cost-sharing at the secondary and tertiary levels of education. Kenyans had to take more responsibility for educating themselves. The independence promises of provision of free education to Kenyans changed to reflect the prevailing economic circumstances. It was argued that education was no longer a right but a privilege, as well as a scarce item. Each one who had access to education was warned to "occupy his [sic] time wisely and learn as much as 
he [sic] can for his [sic] own benefit and for the greater future of his [sic] nation" (Development Plan, 1974-78, p, 22).

The cost-sharing strategy proposed in this Plan demanded that parents increase their financial participation in their children's education through payment of tuition and non-tuition fees. This strategy increased limitations on girls' educational and economic opportunities because when resources are scarce parents are more likely to invest in the education of boys than that of girls due to cultural gendered assumptions surrounding masculinity and femininity. This Plan, however, did not address the impact of cost-sharing strategy within a class and gender-stratified society.

\section{Gachathi Report (1976)}

The Gachathi Report was the second policy document devoted solely to education after independence. It was realized within the economic, political and social context defined by the 1974-78 Development Plan. The Gachathi Report emphasized the need for educational changes not only to cope with the sluggish economy but also to stimulate its growth. The Report was produced by a Committee of 24 commissioners, headed by the Permanent Secretary of the Ministry of Education, Mr. Peter Gachathi. Two of the commissioners were women. One was a headmistress of the oldest African girls high school and the other a lecturer in the Home Economics department in Kenyatta University College. The male commissioners included high ranking academics, heads of post secondary institutions, senior civil servants and successful businessmen.

The commissioners solicited background papers from a select group of academicians and educators. Of the 32 papers presented, only 2 came from female 
academicians, with no doctorates or any significant political or social clout. Invited also for interviews and/or to submit memoranda were representatives of organizations, departments and interested individuals. The commissioners examined the impact of Ominde's educational policies on the economy with a mandate of providing new directions for education in Kenya to stimulate economic growth.

For a decade since the Ominde Report, Kenya's economy had not grown as anticipated. Instead, unemployment and rural-urban migration rates were higher. The transition from a "traditional" society dependent on agricultural subsistence to a modern society had produced undesirable results which had become impediments to economic growth. School enrolments had been accompanied by high drop-out rates. The academic system of education was accused of promulgating the myth that formal education automatically led to high wage employment in the modern urbanized sector of the economy. This myth had resulted in heavy rural-urban migration in search of non-existent jobs (p.xvii). The commissioners claimed that school leavers (graduates) did not have the skills that were required in major areas of national development (Gachathi, 1976). Education had, however, successfully provided some highly skilled labour for participation in the modern sector as well as Africanization of the same.

The country was faced with high unemployment, high drop-out rates and uncontrollable rural-urban migration, problems that were in most ways related to the education system. Although it was perceived that the education system had performed poorly in its role in national development, the commissioners recommended new educational policy directions to be adopted so that education could play its rightful role in 
national development (Gachathi, 1976). Gachathi's Report focused on (a) women and education, and (b) education and rural development as areas that could contribute to economic development.

The Report pointed out that, although half of the human resources required for national development consisted of women, the general status of education and the skills of women had lagged behind that of men. It noted that if national development was to be maximized the basic knowledge and skills possessed by women should at least be equal to those of men. The Report recommended that "basic educational and skill attributes acquired by women be continually supplemented by lifelong and effective non-formal learning since women are also biologically responsible for bearing and rearing children" (Gachathi, 1976, p. 47, emphasis added).

These policy recommendations aimed at addressing gender disparities in educational opportunities in Kenya which had not been addressed by the Ominde Report. The Gachathi Report noted that the underlying reasons for gender imbalances in opportunities were traditions, beliefs and prejudices held by people regarding the roles and occupations of women. The commissioners noted that these had to be modified or abolished. Women did not have adequate formal education and the majority of educated women chose careers that restricted them to gender-specific careers such as nursing, secretarial and teaching. In addition, the Gachathi Report pointed out that "it must be remembered that the prominent life pattern for the majority of women, even for those who have had good education and training will include essential family responsibilities and in terms of careers, this would mean a life of multiple roles and occasional disturbances" ( $p$. 
45). The Report suggested the following policy recommendations to address gender imbalances and increase women's educational and economic opportunities.

(a) make more secondary schools co-educational (to give more girls opportunities in the larger number of boys only schools),

(b) increase opportunities for girls in science,

(c) provide compensatory enrolments for women at the post-secondary and university levels of education,

(d) increase non-formal education and training for women, with particular emphasis on their economic roles,

(e) evolve an integrated structure of non-formal education and training at national and local levels and to give emphasis to the role of women in the economy by recruiting more of them as agricultural and extension officers,

(f) improve the career guidance programme in schools, especially for girls. (Gachathi, 1976, p. 47)

The Gachathi Report also recommended the provision of "free" universal basic education for enhancing the efforts toward equality of economic opportunities and national unity in the country. It stated that the primary level of education would help all citizens contribute fully to social and economic development of the country. Nevertheless, within this "free" education rhetoric, parents had to meet the costs of uniforms, building funds, equipment levies and activity fee (Gachathi, 1976). The latter costs constitute one of the principal impediment to girls' education and are responsible for high dropout rates among primary and secondary school girls.

The Gachathi Report focused on rural areas as sites of development. The Report defined development as the totality of the processes of change aimed at enhancing the quality of life of the people living in rural areas. Although policies relating to rural areas are important to women because women constitute $70-80 \%$ of the rural populations, this is not the reason why the Report focused on rural areas. Rather, the shift from urban to 
rural development was an attempt to reduce the rural-urban exodus of young, predominantly male, job-seekers, in search of scarce employment.

The Report pointed out that the future pattern of national development needed to depend on greatly accelerated rural development. Consequently, Gachathi Report recommended lifelong education for rural development with formal schooling being a peripheral part. Lifelong education was seen as capable of promoting social, cultural and economic values (Gachathi, 1976). Rural-urban migration was associated with formal academic education which instilled white collar job values, poverty and poor living standards in the rural areas. The Gachathi Report linked rural poverty with lack of knowledge, skills and resources. The Report recommended the improvement of the pattern of distribution of incomes and pricing structures in the rural areas as a way to reduce the rural-urban migration. Nevertheless, Townsend (1993) argues that policies on distribution of incomes would have no effect on poverty in rural areas because they are ambiguous and incapable of dealing with rural poverty. Rural poverty is pervasive and limits educational opportunities made available to children and to girls in particular. Townsend argues that policies on poverty would be more effective if there was a commitment to re-distributing wealth from the rich to the poor.

Gachathi Report's policy recommendations attempted to break the "official silence" on gender inequities in educational opportunities. It also drew attention to the multiplicity of roles that women engage in as workers, mothers and/or wives. The Report provided an opportunity for the construction of gender as a category of analysis of 
educational opportunities. Nevertheless, few subsequent policy documents have used gender as a category in the formulation of educational and development policies.

\section{Mackay Report (1981)}

The Mackay Report was produced in 1981 by a Working Party appointed to review the higher education system in Kenya in relation to rural development objectives and to recommend how a proposed second university could best assist in their attainment. The Working Party was appointed by the president of Kenya. It consisted of 17 men, the majority of whom had high academic achievements. They were all high ranking Kenyan civil servants, except the Canadian chairperson, Dr. Mackay.

The country was faced with growing unemployment, intensified by rural-urban migration of school leavers in search of limited employment opportunities in the formal employment sector. Limited expansion of the formal employment sector had forced the government to shift some of its investment from the formal employment sector based in the urban areas to development programmes in rural areas. Policy makers argued that rural development would ensure economic growth, reduce unemployment and curb the rural-urban migration. In addition, they argued that the creation of a second public university would enable the government to maintain its control over higher education which was being threatened by the mushrooming of private universities cashing in on the high number of qualified school-leavers, faced not only with lack of access to the local university and university colleges, but unable to find jobs or create their own. The private universities' curricula were regarded as not being in line with national planning. 
The Working Party recommended the expansion of higher education for rural development. Higher education was seen as having the potential to facilitate the needs of national development objectives "through the production of skilled and high level manpower, dissemination of knowledge, appreciation of national environment and resources, and through research and development of more efficient machinery for the utilization of those resources" (p. 7). The second university, unlike the previous one, therefore, had to be oriented towards provision of skills to enhance rural development rather than for the modern sector.

The Report recommended restructuring of the education system from 7-4-2-3 (seven years primary, four secondary, two advanced level and three years of university) to 8-4-4 (eight years of primary, four secondary and four of university). Each level would be terminal. The Report recommended that all students in the secondary level of education needed to take science and mathematics for graduation. It also recommended curricula changes at both primary and secondary levels with more emphasis on practical courses to provide skills for self-employment. These recommendations were seen as solutions to the growing demand for higher education, unemployment, rural-urban migration and sluggish economy.

This Working Party did not use gender as a category in its examination of education. Its recommendations were based on 12 topics which they felt encompassed the different areas in need of investigation. None of these topics addressed or raised any issue in relation with women. Nevertheless, the recommendations had a direct bearing on women's participation in education and economic activities. 
At the primary level, the Report emphasized practical or vocational courses for self-employment. These included mansory, carpentry and tailoring. Females were limited to tailoring since masonry and carpentry are traditional male trades. At the secondary level, the Report recommended science and mathematics subjects to be made compulsory. This would privilege boys whose schools are well equipped to teach science subjects. At the higher level, the emphasis was on the production of "skilled and high level manpower[sic]" for rural development. The commissioners emphasized scientific and technical skills at the higher level. These are skills that most women do not have the opportunity to acquire because many girls do not study the prerequisite pure science courses in the lower levels of education. Consequently, these recommendations, though outwardly gender neutral, exacerbated gender inequities in access to educational and economic opportunities

\section{Wanjigi Report (1982/83)}

The Wanjigi Report was produced by a committee appointed by the president to examine the unemployment problem with respect to the rural and urban formal and informal employment sectors. This committee consisted of nine men. It was chaired by Maina Wanjigi who also was the permanent secretary in the Ministry of Planning and Economic Development. One member was an academic and the rest were high-ranking civil servants. The Report concluded that, "despite the impressive achievements in improving the living standards of Kenyans since independence, incomes were still low and majority of the people were still very poor" (Wanjigi, 1982/83, p. v). The academicoriented education system was seen as the major contributing factor to unemployment. 
Wanjigi's Report endorsed the Mackay Report recommendations to restructure the education system from 7-4-3-3 to 8-4-4 system of education and to create a second public university. The Report noted that within the 8-4-4 education system, there would be an emphasis on practical skill development and a deliberate exposure to practical problems of the nation (p.51).

Again, poor economic growth, high unemployment rates, rural-urban migration, expansion in education and increasing costs of public education were the major factors that influenced policy recommendations. Expansion in schooling meant an increased number of school leavers. "Education and training was costing Kenya 41 per cent of the Gross Domestic Product, making it the largest budgetary allocation to a single government service"(p. 47).

Education was still seen as a tool for solving social, economic and political problems facing Kenya. The Report recommended that the education system be made flexible, relevant, adaptive and vocational-contrary to the operating one which was said to be weak, inflexible and geared towards white collar jobs despite earlier reports emphasizing vocationalization and rural development. The operating system of education was accused of not adjusting to the changing aspirations of individual Kenyans and to the needs of the labour market in terms of new skills, new technologies and proper attitudes toward work. The commissioners claimed that this characteristic of the education system had resulted in the "paradoxical situation where acute shortages of manpower and massive unemployment exist side by side" (p. 48). The Report stated that:

The primary goal of education in any society is to harness and develop the talents and human potentialities of every individual so that he [sic] can fulfill his [sic] moral, intellectual and material needs and also contribute to the general well-being, 
survival and development of that society. Education is a lifelong process through which an individual acquires knowledge and skills that enable him [sic] to understand and adapt to an ever-changing physical and social environment and ultimately to realize his[sic] optimal worth. (p.45)

The Wanjigi Report claimed that existing problems, increasing numbers of schoolleavers, rural to urban migration, job selectivity, dominance of an academic orientation and problems in personality development, could be solved by an education that emphasized training for self-employment. Education, thus, was to be manipulated to achieve these goals. Prevocational subjects were to be introduced to make primary level education terminal to provide its graduates with skills necessary for self-employment. The Report continued the emphasis on vocationalism and suggested that carpentry, metalwork, masonry, home science, basket making, tailoring and book-keeping be introduced at the primary level.

The Wanjigi Report recommended the removal of the distinction between economic and non-economic activities in relation to women's work in the rural areas since most women were economically active as they contributed most of the labour required for the cultivation of food and cash crops on family holdings. The Report noted that:

The vast majority of Kenyan women, some 88 per cent of the total, reside in the rural areas and most of them are economically active. . . Even when women are not busy with economic activities, they are occupied in household duties, which also contribute to the living standards of the household. . . . Usual estimates of female participation rate in the labour force are thus misleading so far as rural Kenya is concerned. (p.32)

The Report also claimed that, although the majority of women in the formal employment sector worked as casuals, more women were participating in the broader occupational 
groups of professionals, executive and managerial personnel. Wanjigi Report observed that:

With a high population growth rate, increasing scarcity of land for cultivation, growing migration of women to urban areas and rising rates of participation of women in educational system, the percentage of unemployed in the modern sector jobseekers has been higher among women than among men. (p.33)

The Wanjigi Report recommended the introduction of sex education in primary school and primary teachers' curricula since uncontrolled population growth was seen as a major obstacle to economic growth. It justified the introduction of sex education at the primary level on the grounds that "children reached puberty at this stage" and "lack of knowledge about sex and reproduction has been one of the causes of pregnancies among school girls" (p.57). Nevertheless, the Report failed to address the victimization of adolescent girls whose pregnancy marks the end of formal education. The Report, also, did not address the issue of the men who are responsible for these pregnancies who, most of the time are teachers or other mature men. These men often threaten and coerce the girls into engaging in sexual activities and then disown the girls when they become pregnant.

\section{Kamunge Report (1988)}

The Kamunge Report was the fourth Report solely devoted to education. It came four years after the implementation of the 8-4-4 system of education first recommended by the Mackay Report of 1981. The Kamunge Report examined the 8-4-4 educational philosophy, policies and objectives to ensure that they were in consonance with changing social, cultural, economic and political demands of the country. The 8-4-4 system had 
been hastily implemented without physical facilities, workshops teaching and learning materials. Furthermore, the government could not cope with the financial demands of this system. A working party was appointed to work out an intensive cost-sharing plan for financing education and training in the country. The working party consisted of 18 commissioners two of whom were women. Most of the men were senior civil servants. One of these women served as a secretary. The chair of the working party was James Kamunge, the Director of Education.

The Report emphasized the centrality of education and training in helping the nation to meet the many challenges of socio-economic development. It stressed the need for education and training to offer the youth with skills and attitudes that lead to selfreliance, self-employment and prepare for life and employment in the rural areas (p.1 emphasis added). The Kamunge Report noted that although education was a vehicle for economic development, the government of Kenya could not afford to finance the expanding education system. Kenya was under pressure from the World Bank and International Monetary Fund (IMF) to reduce her educational expenditure which the World Bank and IMF claimed had contributed to the increasing debt deficit and was an obstacle to economic development. The World Bank and IMF proposed increased costsharing between the government and communities, parents and beneficiaries of education and training. The Working Party recommended the immediate implementation of the revised cost-sharing strategy, first implemented after the 1974-78 Development Plan. The working party claimed that the increased cost-sharing would "accelerate the expansion of 
education and training opportunities and thereby increase access to education and training at all levels and to ensure their quality and relevance"(p. 2)

The Report did not address gender issues in its examination of the economic problems facing Kenya. However recommended policies such as the increased costsharing strategy would have adverse effect on women's education. The strategy meant that in rural areas, for example, communities would be expected to take more responsibility in the building of schools and teachers' houses. Parents had to cover the costs of books, uniforms, exercise books, activity fees, medical care and additional fees that the community may impose from time to time. The increasing demand for physical and material labour in order to meet these costs has increased rural women's total workload.

\section{9-93 Development Plan}

The 1989-93 Development Plan set the political and economic context for the Ndegwa Report. The Plan pioneered the incorporation of the structural adjustment process. It provided policy guidelines to enhance economic growth, and address unemployment, population growth and rural-urban migration. The Plan was prepared by the Ministry of Planning and National Development.

The Plan attempted to formulate policies that would promote renewed and rapid economic growth, increase productivity in agriculture, raise rural incomes and restructure industries. In this Plan, the general status of women and their role in development was highlighted. The gender discourse on development was in consonance with that in the World Bank Country Study of 1989 which examined the role of women in economic 
development in Kenya. Contrary to the rhetoric on women's contribution to development, the Plan emphasized heavy investment in agriculture in the large scale but not in the small scale sector where most of the rural women operate and earn income to afford their children educational opportunities.

Girls and boys enrolment parity at the primary level was claimed to be a measure of the government's commitment to the provision of equal educational opportunities to girls and boys. This parity, however, was accompanied by a $60 \%$ drop out rate for girls which the government attributed to "social and biological" factors (p.20). These "social and biological" factors were not identified and therefore no policies were recommended to address them.

In the Plan, it was noted that most women did not have the education required to participate in the formal employment sector. Most women were concentrated in the "traditional sector where they made a vital contribution in the production of food and cash crops, raising of livestock and provision of essential domestic services" (Development Plan, 1989-93 p. 28). It was pointed out that women have been slow to rise to prominent leadership positions in modern Kenya because of unfavourable social attitudes. The low status of women in Kenya was associated with colonialism. The Plan claimed that "colonial subjugation and its attendant Victorian attitudes toward women both as workers and partners in life eroded women's economic and social status" (1989-1993 Development Plan, p. 28, emphasis added). The planners claimed that Kenya, however, had been working towards the restoration of women to their active role, not only in the development of the economy but also in the ownership and control of wealth arising from 
economic production. It was claimed that women's quality of life as measured by such indicators as education, health, urbanization, employment and incomes had improved considerably since independence. The Plan, however, did not substantiate what were the "unfavourable social attitudes" that limited women from leadership positions. Consequently, these unfavourable social attitudes remained invisible, and incapable of policy solutions.

\section{Ndegwa Report (1991)}

The Ndegwa Report was produced by The Presidential Committee on Employment to address the increasing unemployment, rural-urban migration and high population growth. The Gulf crisis and a serious external debt burden had made it impossible for Kenya to invest in the economy to improve conditions at home. The Committee, appointed by the president in April, 1990, consisted of 16 members most of whom were senior civil servants. Two of the members of this committee were women with high academic credentials. Both of these women are advocates of women's rights at local and international levels. The chairperson was Philip Ndegwa who was a permanent secretary. The Committee associated unemployment with Kenya's historical colonial legacy of dichotomizing the economy and labour market into urban and rural sectors, formal and informal sectors and large scale and small sectors with a major urban bias.

The tone of the Report, particularly, in relation to women and development, was in line with Kenya's 1989 World Bank Country Study's recommendations. The Report endorsed the World Bank's recommendations such as the emphasis on basic education for women in order to enhance fertility control. The financial support for this project 
provided by The United Nations Development Programme also had an effect on the Report.

The Report emphasized the role of basic education for economic growth and recommended the provision of universal primary education by the year 2000. The Report claimed that (a) farmers and informal sector workers with primary education are one-third more productive than workers who have not had basic education, and (b) educated and literate people are likely to be more productive and will do better in most activities. The Report claimed that the education of women "contributes significantly towards many other desirable objectives such as that of reducing population growth" (p. 161). The Report drew attention to the high levels of illiteracy rates in Kenya, 44 per cent for males and 57 per cent for females.

The Report commended women's economic activities in the informal sector as well as their reproductive labour. It noted women's role in agriculture, food production, cash crop production and in small-scale industries. The Ndegwa Report also noted women's nurturing roles as mothers and custodians of family health and welfare, especially that of young children, as contributing to the quality of the country's labour force. It claimed that women's contribution to development has been widely acknowledged in official policy statements and development literature. In addition, the Ndegwa Report alleged that "the government has directed significant efforts at measures for promoting women's development and in redressing the disadvantages suffered by women during colonial period especially due to the neglect of their education." (p. 229, emphasis added). 
The Report claimed that female representation in the modern sector had risen to over 21 percent in 1990 compared to 12.2 per cent in 1964 . Most of the women in the formal sector, however, were employed in low ranks and were concentrated in the service sector. The Report recommended an increase in number of places for women in key positions in the formal employment sector.

The Report recommended the following deliberate measures to be instituted by the Government to improve women's performance, enhance their productivity and efficiency and increase their employment opportunities.

i) Development planning to be done with specific reference to gender issues,

ii) Government to implement the Convention on the Elimination of All Forms of Discrimination Against Women,

iii) The introduction of a common curriculum for girls and boys in technical training to encourage girls to take up courses that give them more options and opportunities for employment,

iv) A policy to increase the number of opportunities for women in key positions in both private and public sectors,

v) Women, especially in the rural areas be ensured access to information of importance to them. (p. 232-33)

The Report recommended that the government increase women's earning potential by supporting them through home-based income-generating activities such as tailoring and food processing, activities that were particularly suited to women's multiple roles.

The Report also recommended further increases in parents' contribution to their children's education irrespective of the fact that by 1991 many parents could not meet their current $70 \%$ share. This increase has had serious implications for girls' educational opportunities particularly when a family cannot raise its quota. In such situations, a family 
will choose to educate a boy for cultural reasons. Many girls have been denied educational opportunities on these grounds

In general, this Report treated gender issues in Kenya in some detail and made recommendations that aimed at addressing gender inequities. The inclusion of gender issues in this Report could be associated with (a) participants in the Committee, and (b) the development discourse of the time propagated by development agencies such as the World Bank and reflected in Kenya's Development Plans, particularly the 1989-93 Development Plan. Participating in the Committee were two high level female academics. One was Dr. Eddah Gachukia, former chairperson of the national Women's Organization in Kenya, Maendeleo Ya Wanawake (The Progress of Women) and, at present, an executive member of FAWE-the Federation of African Women Educationalist. The other was Dr. Wanjiru Mwagiru, a professor in the local university and a presenter of the monthly "Women in Development" television programme.

\section{Conclusions}

In conclusion, I briefly examine the changes in the policy themes and the treatment of gender in the policy discourse articulated in policy documents.

An examination of the public discourse on education shows that since independence, the education system has undergone a series of changes and restructuring aimed at enhancing social, economic and political development. Economic growth and politics have played a central role in determining the direction of education.

At independence, the Kenya government was faced with two major problems which education was assigned the responsibility of solving. The first and more immediate 
was the need to provide competent Kenyans who could take over from the departing colonial administrators. The second and more challenging was the long-term problem of devising a system of education which would address itself to the complex political, social and economic needs of an emergent nation (Wanjigi, 1982).

At independence, education was called upon to enhance the rights of all citizens unhindered by the consideration of race, tribe and religion. It was to provide the Africans with high level skills and access to professions and senior positions in banking, industry and into all significant activities of the modern world which had been beyond the reach of Africans before independence (Ominde, 1964). Important at this period was the racial factor. The African/race variable, therefore assumed a "genderless" Kenya where opportunities had supposedly previously been limited by race only.

The Ominde Report (1964) also recommended provision of free basic education for all. At this historical point, education was perceived as a right of every Kenyan. This view of education changed in subsequent policy documents. For example, the Sessional Paper \#10 (1965) noted that education was more of an economic than a social service. It noted that economic growth was the guiding principle upon which all policies in independent Kenya would be made and implemented. The Paper warned that free education could not be provided at the expense of economic growth. The 1974-78 Development Plan went further and pointed out that education was not a right but a privilege and a scarce item. It recommended the implementation of the cost-sharing strategy to reduce government spending on education. From this time henceforth, Kenyans were compelled to take more responsibility for educating themselves. 
Subsequent policy documents such as the Kamunge Report (1988) and the Ndegwa Report (1991) recommended increased cost-sharing where parents would have to meet over $80 \%$ of the cost of education. These policy changes attempted to devise a system of education capable of addressing itself to the changing social, economic and political needs of the country at specific historical points. Other educational policy changes have included shifts from emphasis on (a) academic education to vocational education, (b) employment to self-employment, and (c) urban to rural development.

The Ominde Report (1964) inherently emphasized academic education for white collar jobs in the formal employment sector. A decade later, the 1974-78 Development Plan noted that the formal sector could no longer absorb all the school leavers. The country was faced with poor economic growth, high unemployment rate and rural-urban migration problems which were linked to the academic system of education (Wanjigi Report, 1982). This led to the recommendation of restructuring of the entire education system from 7-4-2-3 to 8-4-4 with each level being terminal. The new system of education was to emphasize vocationalization of school subjects to offer graduates at every level skills for self-employment and for rural development (Mackay Report, 1981, Wanjigi Report, 1983, Kamunge Report, 1988, and Ndegwa Report, 1991).

Also, an examination of the policy discourse articulated in the policy documents shows variations in conceptualization of women's role in national development. Some policy documents paid substantial attention to gender issues and women's role in national development while others did not raise gender issues. Introduction of gender issues in the policy discourse was influenced by the focus of the policy document and other factors 
including the prevailing development discourse orchestrated by development agencies and the gender representation in the committees and work parties. Important to this study is the nature of gender issues that were raised and how they were framed. Some documents emphasized the role of women as economic and political agents in the public sphere. They emphasized the need for women to have equal access to higher education and scientific skills to participate in the formal sector. Others emphasized women's reproductive and productive roles in the private sphere and recommended that women be offered basic education and nonformal education that enhanced their delivery of these services.

At independence, the education of women lagged behind that of men since formal education was introduced by Christian Missionaries and developed by the colonial administrators along gender and racial lines. The Ominde Report (1964), although focusing on race issues, recommended girls only secondary schools but rejected appeals for girls only boarding primary schools. The Gachathi Report (1976), however, paid a substantial attention to gender issues. The Gachathi Report noted that although women constituted over $50 \%$ of the human resource required for national development their education lagged behind that of men. The Report recommended policies that would not only increase women's participation in higher education but also in scientific and other traditionally male dominated areas. The Gachathi Report conceptualized women as economic agents in the public sphere. The Report recommended policies that would ensure that women become active participants in all levels of the formal sector.

The Gachathi Report policy outcomes could have been influenced by the United Nations Declaration of $1975-85$ as the women's decade and the participation in the 
committee of Joan Waithaka, who was the Principal of Alliance Girls High School, the first African girls' high school in Kenya. This school has established its reputation as a centre of academic excellence. Kardam (1991) argues that individual actors can effect change.

The 1989-93 Development Plan and Ndegwa Report (1991) conceded that women were under-represented in the formal employment sector and specifically in positions of power. The 1989-93 development plan blamed the under-representation of women in the formal employment sector and specifically in positions of power on prevailing unfavourable social attitudes linked to "colonial subjugation and its attendant Victorian attitudes toward women both as workers and partners in life" (p. 28). While colonialism has had its negative impact on women's economic and political power, pre-capitalists' gendered assumptions continue to be used to deny women social, economic and political opportunities in post colonial Kenya. The Ndegwa Report (1991), however, called upon the government to implement the Convention on the Elimination of All Forms of Discrimination Against Women. In addition, the Report called for a deliberate policy to be put in place to increase the number of women in key positions both in private and public sector. Implementation and enforcement of these policies would have significant changes in the modern sector and in the general Kenya society.

Beginning in the late 1970s, policy makers began to focus on rural areas as sites of development. Even though women constitute over $70 \%$ of the rural population, the focus on rural areas was not based on the women's needs. The focus on the rural areas became necessary because the country was faced with poor economic growth, unemployment and 
rural-urban migration of predominantly male job seekers. Thus, the Gachathi Report (1976) recommended policies to improve living conditions in the rural areas and make them attractive to live in. The Gachathi Report linked rural poverty with lack of knowledge, skills and resources. The Report recommended the improvement of the pattern of distribution of incomes and pricing structures in the rural areas as a way to reduce the rural-urban migration. The push to improve living conditions in rural areas became necessary when rural-urban migration of jobseekers, who were mostly men, became a national problem as they could not be absorbed in the formal employment sector. Wanjigi Report (1982) and Ndegwa Report (1991) focused on rural women's productive roles. The Ndegwa Report (1991) "praised" women for the laborious unpaid domestic work they perform as mothers and wives. They defined women's work to include food production, petty trading, childrearing, care of the sick, the aged and a multiplicity of other activities that women have to undertake to sustain their families' welfare. Wanjigi Report (1982) argued that women's labour in the private sphere contributed substantially to the economic development of the nation, and it should be classified as "economic" rather than as "non-economic" as it had been previously defined.

The Ndegwa Report (1991) and the 1989-93 Development Plans commended women's reproductive labour and its contribution to national development. The Ndegwa Report argued that the country's labour force depend on women's performance as mothers, custodians of family, health and welfare, especially that of young children. The Gachathi Report (1976) recommended that women's basic education and skills be 
supplemented with lifelong and effective nonformal education since women were "biologically responsible for bearing and rearing children"( p. 47, emphasis added). However, women's sexuality was inherently blamed for the high rate of population growth which was identified as a factor contributing to the low economic growth experienced in Kenya. The Ndegwa Report (1991) recommended that women be given basic education as a way of controlling family size since there was evidence that the willingness to use contraceptives increased with education. The implication of these recommendations is that rural families and in particular women have become the target of family planning programmes. The policy recommendations on population growth, women's participation in education, economy, particularly in the in the informal sector were in line with development agencies' policies on development in third world countries. While the policy discourse articulated women's reproductive and productive roles, particularly in the private sphere, the policy discourse did not underscore the gender-related factors that have limited the women's agency in both private and public spheres of Kenyan society. 
Table 2 Policy Reports: Summary

\begin{tabular}{|c|c|c|c|}
\hline Name & Year & Overall Purpose & Treatment of Gender \\
\hline Ominde Report & 1964 & $\begin{array}{l}\text { Review of existing system of education and } \\
\text { advised the government on the formulation } \\
\text { and implementation of new national policies } \\
\text { for education. }\end{array}$ & $\begin{array}{l}\text { Recommended girls only secondary } \\
\text { schools. } \\
\text { Rejected appeals for girls only boarding } \\
\text { primary schools. }\end{array}$ \\
\hline $\begin{array}{l}\text { Sessional Paper } \\
\# 10\end{array}$ & 1965 & $\begin{array}{l}\text { Elaborate on the principles of a democratic } \\
\text { African Socialist State as per KANU } \\
\text { Manifesto declaration. } \\
\text { Economic growth as the guiding principle } \\
\text { upon which all policies in independent } \\
\text { Kenya would be made and implemented. }\end{array}$ & No discussion on gender issues \\
\hline $\begin{array}{l}1974-78 \\
\text { Development } \\
\text { Plan }\end{array}$ & 1974 & $\begin{array}{l}\text { Planning for enhancement of national } \\
\text { development within the context of internal } \\
\text { and external crisis. } \\
\text { Cost-sharing introduced. }\end{array}$ & No discussion on gender issues \\
\hline Gachathi Report & 1976 & $\begin{array}{l}\text { Examination of the impact of education on } \\
\text { the economy with a mandate of providing } \\
\text { new directions for education to stimulate } \\
\text { economic growth. }\end{array}$ & $\begin{array}{l}\text { Substantial attention to women's } \\
\text { education } \\
\text { Recommended policies to address gender } \\
\text { imbalances and increase women's } \\
\text { educational and economic opportunities. }\end{array}$ \\
\hline Mackay Report & 1981 & $\begin{array}{l}\text { Review higher education system in relation } \\
\text { to rural Development. } \\
\text { Restructuring of the education system from } \\
7-4-2-3 \text { to } 8-4-4 \text {. Each level would be } \\
\text { terminal. }\end{array}$ & No discussion on gender issues \\
\hline Wanjigi Report & 1982 & $\begin{array}{l}\text { Examination of the unemployment problem } \\
\text { with respect to the formal and informal } \\
\text { sectors in both rural and urban contexts. }\end{array}$ & $\begin{array}{l}\text { Addressed women's economic activities } \\
\text { both in the urban and in rural contexts. } \\
\text { Recommended introduction of sex } \\
\text { education in schools. }\end{array}$ \\
\hline Kamunge Report & 1988 & $\begin{array}{l}\text { Recommend ways in which education and } \\
\text { training may offer the youth skills that lead } \\
\text { to self-reliance and self-employment. } \\
\text { Work out a cost-sharing plan for financing } \\
\text { education and training. }\end{array}$ & No discussion on gender \\
\hline $\begin{array}{l}1989-93 \\
\text { Development } \\
\text { Plan }\end{array}$ & 1989 & $\begin{array}{l}\text { Pioneered incorporation of the structural } \\
\text { adjustment process. } \\
\text { It provided policy guidelines to enhance } \\
\text { economic growth, to address the problem of } \\
\text { unemployment and population growth. }\end{array}$ & $\begin{array}{l}\text { Commended women's economic activities } \\
\text { growth particularly those women living in } \\
\text { the rural areas. } \\
\text { Reiterated government's commitment to } \\
\text { the provision of equal educational } \\
\text { opportunities to both boys and girls. } \\
\text { Low status of women in the formal } \\
\text { employment sector was associated with } \\
\text { colonialism }\end{array}$ \\
\hline Ndegwa Report & 1991 & $\begin{array}{l}\text { A committee appointed to map out strategies } \\
\text { to deal with the increasing unemployment, } \\
\text { rural-urban migration and population } \\
\text { growth. }\end{array}$ & $\begin{array}{l}\text { Commended women's economic activities } \\
\text { in the formal and informal sectors. } \\
\text { Recommended policies to enhance } \\
\text { women's reproductive and productive } \\
\text { roles. }\end{array}$ \\
\hline
\end{tabular}




\section{Chapter 5}

\section{KILOME WOMEN'S EDUCATIONAL EXPERIENCES}

In this chapter I examine Kilome women's own educational experiences and those of their daughters. The discussions with the women about their experiences of education show that their fathers, who controlled and allocated economic resources in their families, favoured the education of boys rather than that of girls. The women's stories reveal that some fathers did not invest in the education of girls because they did not consider education of women important. These fathers could afford to educate all their children and chose to educate only their sons. For other women, their fathers' choice of who was to be educated became necessary when they were faced with the lack of economic resources. At these times, fathers chose to invest in the education of their sons for cultural reasons. The women were forced to leave school and eventually get married to have their "own homes." Marriage seemed to be the only option available to them.

First, I discuss the colonial legacy of education in Kenya. Present-day gender inequities in formal education can be traced to the colonial policies on education in which formal education was developed along gender and racial lines. Next, I discuss the women's experiences of education. The women's experiences show that gender was used as a criterion in the provision of educational opportunities. Consequently the women were denied educational opportunities equal to those of their male counterparts. Lastly, I present the educational experiences of the daughters of these women. The girls' experiences as told by their mothers and also by some of the girls. These experiences give 
a glimpse of the gender factors that continue to limit girls' access to educational opportunities in contemporary Kenya. Presented last are the conclusions on women's own experiences of education and those of their daughters showing that women in Kenya do not enjoy educational opportunities equal to those of their male counterparts. Mothers in contemporary Kenya, however, are aware of the importance of women's education and they have become intervention agents for their daughters education unlike mothers of the previous generation.

\section{Colonial Background}

Traditionally, gender divisions of labour were relatively clear. Men cleared the land and prepared it for planting, looked after cattle, went hunting and fought in tribal wars. Women concentrated on household chores, cultivated the plots that men cleared, planted and harvested food crops (Sifuna, 1990). Women, also, "were full participants in the economy beyond the household and played significant roles in the political decisionmaking process" (Staudt, 1987, p. 189). Women had more equitable access to resources than they did under colonialism, and parallel female and male authority structures often helped to protect women's interests.

The coming of the Europeans and the onset of colonialism dismantled precapitalist gender roles. Men were given a semi-formal education to prepare them for work in settlers' farms and in the lowest echelons of the colonial administration. On the other hand, women were left in the rural areas in charge of all the household work. Men were prepared for entry into the world of paid work while women were left in the villages to provide unpaid work to subsidize men's poor wages. 
Colonial policies were detrimental; they discriminated systematically against women in limiting access to such new critical resources as Western education and wage labour (Robertson, 1986; Stamp, 1989). Attempts by women to participate in the formal employment sectors, particularly in the urban centres, were not encouraged by the colonial administration. In addition, Obbo (1980) argues that "lovers and husbands positively resented the employment of women because it brought them in contact with other men and afforded them some degree of economic independence" (p.10). The consequence of this has been the translation of precolonial gender divisions of labour into relations of domination and exploitation of women (Freeman, 1988). The colonial legacy of women's exclusion from formal education and employment sector has continued in independent Kenya.

Kilome women who participated in this study attest to the continued preferential treatment of boys in being accorded educational opportunities. The women's discourse on education show that cultural beliefs about femininity limited the women's formal educational opportunities. This became evident in our discussions on the education of women. The women talked to me about their views of girls' education, whether it is necessary to educate girls and to what level. Then I brought the issue of women's education closer to them by talking about the education of their own children and in particular their daughters. We discussed the constraints and possibilities they face in their attempt to afford their children educational opportunities and how these experiences are related to their past educational experiences and their access to economic opportunities. Finally, we talked about the women's formal education, exploring what shaped their 
experiences and why. I present the women's own experiences of education in the following section.

\section{Women's Own Experiences of Education}

A preference for sons in according educational opportunities is one factor that forced some Kilome women to leave school. This gender divide in the provision of educational opportunities is centred around the cultural assumptions and meanings associated with being male or female as defined and shaped in precolonial, colonial and post-colonial Kenya. The interplay between the cultural definitions of women, in particular the belief that girls will get married and leave their family and the fact that parents have to invest in their children's education, has limited girls' educational opportunities. Girls are viewed as temporary members of the family and potential mothers capable of "terminating" their schooling to pick up their more "significant" roles of being mothers and/or wives.

Several women from all the sites, Kyandue, Kithumba and Salama, noted that they had to leave school because their parents, particularly fathers, did not believe in educating women. Among these women were Ngina, Mwikali, Meli and Janet from Kyandue village. Ngina's father, however, paid school fees for his sons until they decided to leave school. (In this study I use $\mathrm{MN}$ to denote the voice of the researcher and the first two letters of the women's pseudonyms. I also use two ellipsis points to indicate a pause).

Ng: I left school in standard three because there was no school fees for me. There was no money to educate me and they (parents) did not know the usefulness of educating woman like me and I believe if they knew how useful education is, they would have struggled to educate me.

MN: Did you have brothers and did they get an education? 
Ng: Yes. I have three elder brothers. The boys continued with their schooling and left school in Standard 6 voluntarily to go and work.

MN: So there was no money when it came to investing in the girls' education?

Ng: Yes it becomes harder to educate girls but for a boy, it seems as though the money to pay for their education somehow is made available.

MN: Do you have sisters?

Ng: I have two elder sisters and the eldest got married long time ago. They never received any formal schooling. They were given traditional education--their teeth were carved and they learnt how to dance traditional dances (kwina wathi).. that's all they got (Interview, July 1994).

Ngina feels that her parents were not aware of the importance of women's formal education. They expected her to do all the female-related chores performed by grown women. Ngina's parents prepared her for female roles in the private sphere as a mother and wife to be a childrearer, food producer, caregiver and to provide all other labour required to sustain the household. She was not prepared to take up a major role in providing the resources required to afford her children educational opportunities.

Ng: The two last years that I went to school I did it (paid school fees) by myself.. just trying to keep myself in school against all odds (kwisukumiiia).

MN: And you were very young to do the things you were doing to earn money? Ng: Yes, I was but I used to thrash sisal every Saturday. That was nothing compared to the work I used to do in the plot.

MN: What work did you do at home after school?

Ng: I had lots of work to do. I used to look after the cows, fetch water, dig, and plant when it rained. So I was asked to perform most of the roles that a grown woman performed and also the work that my brothers should have been doing but they were not at home to do their work. So, I feel that my parents did not encourage me to get an education. My parents just wanted me to concentrate on what women do, not to go to school but work in the shamba [plot], collect firewood, fetch water, grind millet, cook and a whole lot of things.

MN: Why?

$\mathrm{Ng}$ : Because our parents were not educated. I think if they had been educated they would have been different. I think they used to believe that.. when a girl was born everybody expected her to get married since she is a "woman" (Interview July 1994). 
Women who do not get married and have children outside wedlock are considered bad role models. Many mothers, like Ngina's mother, still teach their daughters domestic skills in preparation for their "own" homes.

Meli, too, left school after one year of formal education in the mid 1960's. Her father chose to educate her brother instead of her. Meli, who is about 45 years of age, enrolled in primary school when she was already a matured girl. She left school and stayed at home helping her mother with household chores and later got married. She has seven children, four girls and three boys. She points out that, "I only went to standard 1 and my father did not want to educate my sisters and me. He was a drunkard.. He only educated our last born brother who is a teacher now" (Interview July 1994).

Thirty three-year old Janet, a mother of five, was asked to leave school temporarily after nine years of formal education (Form 2$)^{1}$ to ease her father's burden of paying school fees for four children in the secondary school level. She was the only one asked to leave school, her three brothers continued with their education. Janet never went back to school. Getting married was the only option that Janet felt was open to her.

Ja: When I was in Form 2 at the same time I had three brothers in Forms 4, 3 and 1 and my father was carrying a big burden and I was told to stay at home for some time and I will be taken to school later. I sat ${ }^{2}$ at home and I never went to school. All my brothers, even the little one who was in form 1 when I was in form 2, went up to form 4 while I was still at home. I stayed home for three years and I decided to have my own home (get married).

$\mathrm{MN}$ : Why did you choose to get married?

Ja: What else could I do, I had sat at home for 3 years and they didn't seem to want to take me back to school. They did not mention anything to do with my schooling for all those three years I sat at home. Although I think my father really wanted to see his children educated he drinks too much to care (laughs).

MN: But he didn't buy alcohol with his sons' school fees!

\footnotetext{
${ }^{1}$ The education system in Kenya is divided into primary, secondary and tertiary levels of education. Primary level starts from Standard 1-8 and Secondary from Form 1-4.

2Janet helped her mother with all the household work, although she notes that she "sat at home."
} 
Ja: Actually he seemed to really want to educate the boys but not us girls because my elder sister had to leave school in form 3 because of school fees. She later got married (Interview, July 1994).

Kithumba women too pointed out that their educational opportunities were limited by their parents' preferential treatment of their brothers in according educational opportunities. These women, Manduu, Mumo, Katunge and Maria. Mumo and Manduu are the oldest women who participated in this study. For the two older women, their parents and fathers in particular, did not believe in the education of women. Mumo and Manduu point out that in the late 1930s and 1940s when they were going to school, most parents did not value women's education. Parents feared that education would "spoil" their daughters since they would leave the village to go the city to look for paid work. Mumo points out that in the late 1930s, those parents who allowed their daughters to go to school only gave them enough education to be able to read and write letters to their migrant husbands.

MN: How long did you stay in school?

$\mathrm{Mu}$ : I stayed in school for only four years and then I was supposed to go to intermediate school and my father told me that I could not go to the intermediate school which was at Mbooni about 50 kilometres from here. For them, that was too far. He told me that I had already had enough education since I could read and write.

MN: What about your brothers? Did they go on with school?

$\mathrm{Mu}$ : Oh yes. My brothers remained in school but only one of them was very good in school. He became an electrical engineer with Power and Lighting. Us girls we were very good in school, my younger sister, especially, was very good. She had such a good brain but she too had to leave school after Standard 4 because my father said that was enough for her. She later got married and died (Interview, June 1994).

Manduu who is about 52 years old was discouraged from continuing with formal education by her parents. She was withdrawn from school to stay at home and help her 
mother with domestic chores as she awaited a suitor. Her brothers were encouraged to go on with formal education with the father paying the small amount of fees that was required at that time. Manduu observes that:

Ma: I only had one year of schooling and I left school. I had a very good mind because within one year I learnt how to read and write in Kikamba and now I know how to read Swahili. I had to leave school and after a short time I got married ${ }^{3}$. My brothers did not have to leave school as I did. They went up to Standard 6 (grade 6) of those days and were able to look for work in the city. For them it was O.K. but all this is because parents those days did not know the importance of a woman's education as we know today. Parents those days believed that girls who got educated got spoilt because they would go to the cities to look for employment like men. They believed that their daughter will become a prostitute..she would be out of sight and beyond her parents' control. And when she decided to get married, she would marry a stranger. Parents of those days wanted their daughters to be married to their friends' sons who would pay bridewealth (Interview, July 1994).

Mwelu, who is about 40 years old and a mother of seven, had four years of education. She spent these four years in school with her mother's support but against her father's wish. Her mother looked after the cattle, a task assigned to Mwelu since her brothers had entered formal schooling. Mwelu stayed in school for as long as the mother could afford to pay her fees. Mwelu left school at the beginning of the intermediate level (grade 5) when her mother could no longer afford to pay her fees. Mwelu had the following to say:

I went to school when I was a big girl and I left four years later. My going to school was like a mistake because my father never used to educate girls and he had said that he would never educate girls. Up to that level, I was educated by my mother. I was supposed to look after the cattle because in my family, girls were the ones who looked after the cattle. I was the first of the girls to get some formal education. In my mother's house, I am the only girl who knows how to read and write (kwiyiandikia) and we are a family of five girls and two boys. The others never went to school. I went to school as though I was hiding (niilye oouu ta

\footnotetext{
${ }^{3}$ In those days, girls would start schooling when they were mature. The aim was to help them to be able to read and write letters written to her by her husband.
} 
niivithite). My father harassed my mother a lot because of letting me go to school and looking after the cows when I was at school (Interview, July 7, 1994, emphasis added).

Traditionally, among the Kamba people, boys looked after the livestock. However, with the introduction of formal education along gender lines, more boys enrolled in schools and these traditional tasks were assumed by girls and women thereby increasing their total workload.

Mwelu's brothers were given the opportunity to get formal education to the levels they desired. They have been able to get paid employment and in turn support their families and educate their children.

MN: Were the boys educated?

Mw: Yes. The boys were educated. They got the education that was available at that time. One went up to Standard 8 of those days and he got a teaching job and today he supports his family and himself with his education and the other one got up to Standard 6 of those days and he refused to go on with education and he was lucky. Even today he still gets jobs in offices with that level of education (Interview, July 1994).

Mwelu's opportunities to enter into paid employment were significantly limited by her lack of educational opportunities. Nevertheless, Mwelu needs to earn money to feed, cloth and educate her children. The survival of her family is dependent on her ability to create income opportunities for herself since her husband has a limited income and is a heavy drinker.

Maria, the most educated rural woman that I interviewed, had 13 years of formal education. Maria was educated by her mother. Her father made it clear to her that he would not invest in her education but was prepared to educate his sons. Maria's father, 
however, paid the sons' school fees until her mother objected to his marriage to a second wife.

My mother paid my school fees because my father said that he would not or never educate girls. That's how I got an education. But in 1981 my father stopped paying school fees for my brothers because he disagreed with my mother. My mother had to go to work in a coffee plantation (150 kilometres away) in order to pay my brothers' and my school fees. I am the only one who got advanced level education in my family (Interview, July 1994).

Nduki, Mbeti and Kambua from Salama town left school after sitting for their secondary school entry examinations because their fathers refused to pay their secondary level school fees. The three women's fathers denied their daughters education not because they had not seen evidence of the importance of women's education or because of the scarcity of resources, but because the fathers did not value the education of women sufficiently to invest in it. Unlike in the 1930's in the case of Mumo and in the 1950's for Manduu when most parents thought education would have a negative impact on women, Nduki and Mbeti left school in the 1970s and Kambua in the early 1990s. They stayed at home helping their mothers with household work until they left home to look for paid employment in Salama and to get married.

Nduki and Mbeti, now both about 35 years old, had seven years of primary education in the previous 7-4-2-3 system of education and Kambua aged 19 had eight years of primary education in the current 8-4-4 system of education. All three women note that they left school because their fathers simply refused to pay their school fees. These women's mothers had no resources with which to pay for the education of their daughters. This is illustrated by the women's stories below. Nduki separated from her husband about ten years ago. She has built a house for her two sons and herself in her father's compound. 
Nd: I was born in 1958 and I left school in 1972 after Standard 7. After this I went to work as a house girl.

MN: Why didn't you go to form 1 ?

$\mathrm{Nd}$ : When I finished Standard 7, my father brought a lot of problems saying that he will not educate girls, and you know old men from our place, sometimes they are advised by other men not to educate their daughters, and so he refused to educate me.

MN: Are you the first born?

Nd: Yes, and so when he refused to educate me I stayed at home for a short time and I went to work as a house girl.

MN: Where did he tell you to go or do?

Nd: Where(Va mwa)! Do you know all my younger sisters have had to leave school at Standard 8? Yes. The last born went up to Standard 8 and he (father) said that he will not pay her school fees.

MN: Even today he is still refusing to educate his daughters?

Nd: Yes. He has refused to pay school fees for us girls.

MN: What about the boys?

Nd: Those ones he tried, all of them went up to Form 4 (12 years of formal education).

MN: So when you girls get to the end of the primary level, where does he tell you to go?

Nd: When he told me that he was not going to educate me, I was really confused and I saw that there wasn't any other life for me. My mother too was so much under his control, she had no voice and she couldn't say anything. My mother is one of those women who cannot discuss anything with her husband. In the first place my father is a very harsh man and even when my mother suggests anything to him, he doesn't listen to her. Anyway, I stayed there (home) for a short time and I went to work as a house girl. I worked for a short time.. do you know I was very young I couldn't really reason out properly and I got married because I didn't know what to do. I was very young, just 15 years. I was not of age and I had not planned to get married but I got married anyway but our marriage did not last very long. He neglected us (my son and $\mathrm{me}$ ) and so I had to get help from my parents' house (Interview, September 1994).

Mbeti tells a similar story of her father's refusal to educate her.

$\mathrm{Mb}$ : I went to school and left in Standard 7 not because my father couldn't afford to educate us but he just did not want to educate girls and that has always shocked me. My mother couldn't manage to pay my fees as there was also another girl in school. So I left school and I sat at home for a long time and I saw the number of problems just increase beyond what we could bear. My father was not supporting us, neither was he supporting my mother and so I decided to go and work and help my mother and I left to come and work for her [mother]. I have educated those who were behind me (younger).

MN: To what level? 
$\mathrm{Mb}$ : Some went up to Form 4.

MN: How were you doing it?

$\mathrm{Mb}$ : I saved money and took some dressmaking courses. I continued to work very hard after this and I am now self-employed. I have rented a sewing machine and I am a seamstress and that is how I earn the money to support my mother, brothers and sisters (Interview, July 1994).

Mbeti is single and has no children of her own. She has worked very hard to give her siblings the educational opportunities that she was denied by her father. She left home and went to look for work to assist her mother to educate her siblings. Mbeti's mother could not leave her home to go and work outside the home because she is responsible for the day-to-day running of the household. Her mother is responsible for all household chores, child rearing, caring for the sick and old, food production, raising animals-a multitude of responsibilities that demand her full-time attention. These responsibilities limit a woman's participation in the income-earning activities outside the home.

Kambua, too, had to leave school to work at Salama, about 40 kilometres away from home as a barmaid because her father, the only income earner in her family, wouldn't pay her school fees. She received eight years of formal education and wanted to get secondary education like her brothers. However, Kambua was asked by her father and elder brother to repeat Standard 7 even though she had passed Standard 8 and had been admitted into a local secondary school. Kambua's father, who holds a well paying job with a government corporation, had chosen to invest in the education of his sons. Kambua's mother could not intervene for her.

Ka: I went up to Standard 8, I finished and I passed. My father told me that he would take me to secondary school, I stayed at home for three months (a full term) and then they told me to repeat Standard 7 not even Standard 8 can you imagine! I thought this was impossible and so I came here and got a job and started working. I started working last year in May (1993) when I realized that they were not going to take me to school. 
MN: What did they say about your coming to work as a bar maid?

$\mathrm{Ka}$ : I left home without telling them where I was going, I just left home and came here and worked for four months and then I went home, that was in August and I told them that I no longer wanted to go school (Interview, September 1994).

Kambua's brothers, even those who did not pass their secondary entry examinations, were given secondary education in harambee ${ }^{4}$ schools.

MN: Why didn't they take you to school?

Ka: I really don't know. You cannot imagine that all my older brothers were taken to school and some of them had not passed their secondary entry examinations. At least, I had tried very much and I had been called to a secondary school! So I did not see why they wanted me to repeat, I thought my father and brothers were treating me disrespectively and so I said that God will help me even if I am denied an education. Of all my brothers, only one of them did well in his secondary entry examinations and was called to a government maintained school. The rest, my father has had to find them secondary schools but for me.. no (Interview, September 1994).

The stories of these women reveal patriarchal control over women's education.

Lack of educational opportunities has left these women with very few economic opportunities. For instance, Kambua works as a barmaid. This is a job that she never thought she would be doing but picked it out of desperation. When Kambua was in school, she hoped to complete her secondary level of schooling and train as a nurse or a teacher. These professions require at least 12 years of formal education with good passes in mathematics and a science subject, biology or chemistry. Kambua's story below illustrates her dilemma.

Ka: I took this job because it was the only job that I could find. I was desperate and I needed money. It was hard to accept to work as a bar maid.. you know it is not a good job, it is bad because sometimes our patrons say horrible things to us. They call us men "trappers." The women who live and work here in Salama are not good either, those women who are not working as bar maids feel that they are doing better jobs than us.. like those who have small business. They too call us prostitutes. The men too are bad. When they see you there in the bar they think

\footnotetext{
${ }^{4}$ Harambee schools are schools that have been built by the local community. Government's assistance to these schools in minimum. This has a negative impact to the quality of instruction.
} 
that you are there for them (prostitutes). They don't respect us at all, they call us prostitutes.. I just persevere these insults because I know that I am not a prostitute and this is not what I really wanted to do.

MN: What did you plan to do if you had gone on with education?

Ka: I wanted to train as a teacher or a nurse after my fourth Form. I thought it was nice for me to become a nurse or a teacher. I had no intentions of leaving school but you see what hurt me is that they wanted me to repeat Standard 7 not even 8 in another primary school that is so far from my home. I thought that was being cruel. They had no reason to ask me to repeat (Interview, September 1994).

Even though Kambua aspired to become a nurse or a teacher, training opportunities are limited by qualifications and space. Kambua's chances of ever being considered for teaching or nursing were reduced to nothing when she was denied secondary level education. Nevertheless, Kambua hopes to quit working as a barmaid to get married and have her "own home."

Kambua's mother was not in a position to speak for her daughter. Her son's views on the future of Kambua were more valued by her husband--a very traditional view where women are considered inferior to the male children.

MN: Was your mother among them in making the decision not to educate you? $\mathrm{Ka}$ : Now with my mother not working..her work is just to stay with us she had no power to speak on this issue. My father is the one who works and decides how the money is to be used. He works with Kenya Power and Lighting. MN: Your father has a regular job?

$\mathrm{Ka}$ : Oh yes. He has a very good job and he is well paid but his money has no effect on my life. I will never want to know the usefulness of his money. I have my own hands, I will try to work with them.

MN: Who helped your father make the decision not to educate you?

$\mathrm{Ka}$ : My eldest brother. He is the one who suggested that I should repeat instead of going to Form 1 and my father agreed with him (Interview, September 1994).

\section{Educational Experiences of women's daughters}

Recent statistics on education show that the enrolment rates of girls in Kenya, particularly at the primary level, are approaching parity with those of boys. In 1991, girls 
constituted 48.7 percent of the total enrolment, a gender ratio that has remained constant since 1989. However, a large number of girls who enrol in Standard $1^{5}$ drop out of school before they reach Standard 8, the last year of this level. For example, of the 864,593 pupils who enrolled in Standard One in 1984, $58.4 \%$ of the girls and $53.6 \%$ of the boys left school before completing Standard 8 in 1991 (UNICEF/GOK: Women and Children, Situation Analysis, 1992; Economic Survey, 1992). The high drop out rates among girls are indicative of the existence of gender-related barriers that steer more girls than boys out of the education system.

From the women's stories, it becomes clear that gender has continued to be used as a criterion for provision of educational opportunities. Men and fathers, particularly in the case of these women, have the economic power from employment or inheritance (property, land) and make decisions on who is to be educated. Their decisions are influenced by (a) gendered cultural assumptions, (b) competition for scarce resources, and (c) perceived value of women's education.

Janet notes that most men do not appreciate the value of women's education in the modern environment. She is concerned about her daughter who is in Standard 6 and will be sitting for the secondary entry examinations in two years. Janet's husband, a primary school teacher, has already indicated that their daughter will not receive secondary level education but she will receive vocational ${ }^{6}$ training in a village polytechnic after Standard 8. Although vocational skills such as dressmaking, masonry, tailoring, brick making are taught in these village polytechnics, Janet feels that her daughter's employment and

\footnotetext{
${ }^{5}$ To be admitted to Standard 1 a child must be at least six years old.

${ }^{6}$ The vocational training offered in village polytechnics is rudimentary and offers very limited income generating opportunities.
} 
income opportunities will be limited if she leaves formal education in Standard 8. She does not want her daughter to leave school at that level. Janet has no paid employment, but she is working out ways of accumulating finances to afford her daughter secondary level education.

Ja: I really don't understand the way men are. You know how they can be.. you can't really tell what he is up to and I have been trying to stress to him (husband) the importance of giving our daughter a chance to go to secondary school but he doesn't want to listen to me. So I decided to plant a lot of French beans and sold them and saved all the money secretly (ngilitye ki). I then used this money to start a small business. I sell maize (corn) meal in a Kiosk. I am working very hard for my daughter's sake otherwise she will not see the inside of a secondary school because my husband does not want to pay for her secondary education. It is hard to understand why he is refusing to educate her but I will do my best. I don't want my daughter to go through what I went through (Interview, July 1994).

Janet, however, needs more than finances to provide her daughter the education that she deems meaningful. Janet might be forced to make a choice between disobeying her husband and educating her daughter which might threaten her marriage. Nevertheless, for the time being, Janet is working hard to save money to accord her daughter educational opportunities denied her by her father for being a woman.

Twenty eight year old Kavuli from Kyandue village, too, is concerned about her daughters' education. She has four children, all of them girls, and feels that the husband is not concerned about their education. At the time of this interview, two of her school-aged daughters were still at home because her husband had not bought them the required class textbooks.

MN: How many children do you have?

$\mathrm{Ka}$ : I have four children and all of them are girls.

$\mathrm{MN}$ : Are they in school?

Ka: Right now they are not going to school. I really cannot explain to you the reason why they are not in school because it is so hard to understand. You see, 
the girls were sent home because they did not have the textbook required in their class. This was almost four months ago and they are still at home.

MN: Why haven't you tried to get them the textbooks? Aren't you delaying them a lot?

$\mathrm{Ka}$ : I don't know how to answer that question because I just don't understand what their father wants to do with them. These girls are missing a lot. One is seven and the other one is eight years old and it is not like that this man is not working. He works for another woman as a casual labourer, it's not that he doesn't have the money, he just does not seem to want to take these girls to school. Every time I ask him about when the girls will go back to school he tells me not to worry and that he is going to see their teacher. When I push him to let me go to talk to the teachers he gets angry. It is very hard to live with such a person.

MN: Do you think he is not interested in their education?

Ka: I really do not know. It could be because he does not want to put his money in the education of girls.. I really can't tell.

MN: What are you doing about it?

Ka: I don't have money to buy these books right now because he has stopped me from braiding hair and that is where I was getting my own money to do my own things. Right now, I am waiting for my turn to get my credit from the women's self-help group that I am a member and I will insist on buying these books for them. If he refuses, I will have to take other measures (hatua) to ensure that my children get educated (Interview, August 1994).

Ndele tells of how her husband never prepared to give their daughter secondary

level education. Without Ndele's initiatives, her daughter would not have sat for her university entry examinations in December 1994.

Nd: I started making traditional baskets when I took my daughter to secondary school. When she entered Form 1 had a lot of problems (thina mwingi muno). I used to be told by teachers that my daughter is very good in class and therefore I should look for money to take her to secondary school. They knew that she would pass her secondary entry examinations. When I would tell my daughter's father what the teachers were saying about her, he would tell me not to panic, he will educate her. I advised him to start saving with the Post Office because I have been told that the child is good at school. He would assure me that there will be no problem when the time comes. The problem came when my daughter did her examinations to go to secondary school the father lost his job, this was about four years since I had started asking him to save money to educate her. So I started wondering what to do with this child, the father is not working and she was called to Kasikeu secondary school. I wondered what to do because I did not have any money and the father had saved nothing.

MN: He hadn't saved anything? 
Nd: No. He hadn't saved anything not even a cent! . . . I felt very poor in my heart and I wondered what this child will do being the first born and a girl and I did not want her to get married as I did. Then I just put a lot of effort and tried the best I could to get her to school. This is about four years ago and surely he does not know how I manage to pay her school fees. I don't even know what he is doing in Namanga (border of Kenya and Tanzania). Can you imagine what would have happened to my daughter? (Interview, July 3, 1994)

The interviews with the high school girls attest to the crucial role that mothers are playing in the education of their children. Ndele's daughter noted that without her mother's hard work, she would probably be working as a housegirl or even married.

MN: What class are you in now?

Ja: I am in Form Four. I will be sitting for my university entry examinations at the end of this year.

MN: Who has been paying your school fees?

Ja: My mother has been paying my fees. It has been very hard for her to pay my fees and to look after the family without much help from my father. She raises some of my fees by fetching water for the school. She wakes up very early in morning to go to the well to fetch the water. Also she makes baskets and sells them. That is how she manages to keep me in school.

$\mathrm{MN}$ : Where is your father?

Ja: I understand he is at Namanga. I don't know what he is doing there but we rarely see him and he sends nothing to us. I understand he might not be working. So, we just rely on our mother. Without her I would not have come this far and so I am working very hard to pass my university entrance examinations (Interview, June 1994).

Women in Kilome division are concerned about men's indifference towards the education of girls. They have realized that the education of their daughters depends on the mothers' ability to contribute the physical and material labour demands associated with schooling.

\section{Conclusions}

The women's stories show that women in Kenya do not enjoy educational opportunities equal to those of their male counterparts. Fathers who have continued to be 
the principle "breadwinners" in the household control the allocation of resources and have tended to invest more in the education of their sons than that of their daughters. Gender has continued to play an important role in determining who is given time and resources to get educational skills and thus participate in economic roles in the public sphere.

The women's stories show that sons were provided with the resources that they required to access educational opportunities, while the girls were forced to assume roles that were their brothers' the precolonial context. The choice on who was to be educated was based on gendered cultural assumptions about femininity and masculinity. Girls were seen as potential mothers with the major responsibility of childbearing and rearing. The sons were seen as future heads of households, breadwinners and bearers of the family name. The women left school and helped their mothers with the household chores and eventually decided to have their "own homes." Getting married was the only viable option for most of these women. Two younger women, however, chose to find any available paid work to help their mothers. As Maina (1991) observes, gender is an important category along which power, property, prestige and social regulation are organized, regulated, distributed and given meanings in a gender-stratified society. Nelly Stromquist (1987) also observes that cultural norms and division of labour within the home limit girls' educational opportunities, being defined primarily as future mothers. She further argues that these cultural norms are not challenged in schools, instead, they are reinforced. 
Nevertheless, we see that in the present context, mothers are taking an active role in the education of their children, and daughters in particular. They have become crucial intervention agents for their daughters in the provision of educational opportunities. As Cubbins (1991) observes, women's economic power has a positive influence in the education of both girls and boys. 


\section{CHAPTER 6}

\section{Factors Limiting Girls' Educational Opportunities}

This chapter deals with the factors that women identified as limiting girls' schooling in Kilome division, Kenya. The women's discourse on education shows that gendered cultural assumptions about femininity are invoked to deny women/girls educational opportunities equal to those of their male counterparts in contemporary Kenya. They identified (a) traditional preference to educate sons, (b) the assumption that girls will get married, and (c) girls' potential motherhood as the gendered cultural assumptions that limit girls' schooling. The rising cost of education has exacerbated gender inequities in the provision of educational opportunities in Kenya and has become a major barrier to girls' education. Pervasive poverty among many rural households delineates the circumstances upon which decisions on whose education is worth investing in are made. The women's articulation of the factors that impede girls' educational opportunities is matched by their determination to challenge these barriers and afford their daughters educational opportunities denied them by their fathers because of social, cultural and economic factors. I first discuss the high cost of education followed by a discussion on son preference, girls' marriage and girls' potential motherhood. Next is a discussion on responsibility for sex education. Finally, I discuss poverty in rural areas. 


\section{High Cost of Education}

High cost of education, particularly at the secondary level, has become a major limitation to children's and in particular girls' educational opportunities in Kilome Division and in Kenya today. The government has reduced its spending on education as part of its implementation of the structural adjustment programs. Parents have to invest more in the education of their children through the cost-sharing strategy, and school fees have skyrocketed. Besides paying school fees, parents have to purchase textbooks, stationery, mattresses, bedding, cutlery and many more items depending on the school. Previously, the government provided most of these requirements. The financial demands have become unattainable for most families who rely on a single income or have no income at all. For a long time, men have been the only income earners in a family. However, this study shows that the financial demands on each household are way above the incomes from most wage employment. Consequently, women and mothers have had to engage in a multiplicity of activities to increase the family's income to meet, and barely so, the financial needs of their families.

Mulee, a mother of eight, points out that she has not been able to pay her daughters' fee balances and, therefore, these girls' secondary level certificates are being held by their respective schools until she pays the 9,200 Kenya shillings (Ksh) they owe.

Mu: All my children have had to struggle to get an education. Like now Minoo who left school in 1992 has not been able to get her Form 4 certificate because she has a fee balance of Ksh. 1200 and Mueni had passed very well and went to Kimangau girls and finished school but she will never see her certificate because she owes the school 8000 Kenya shillings. I went to beg the principal just to let her do the examinations.. she missed going to university with 4 points or 3 points. ${ }^{1}$

\footnotetext{
${ }^{1} \mathrm{~B}$ - is the cut off grade for entry into university. Missing university by 4 or 3 points means that her average lay 4 or 3 points below the cut off grade.
} 
She is the last of the big girls. The boy was here today for half-term but at the same time coming to collect his school fees balance (Interview, July 1994).

Because of the high cost of schooling, more women are having to leave school without the necessary credentials and/or skills to participate in the economic activities in the public sphere. As Wausi and Mutheu, two professional women who participated in this study, point out, women's education is worse off than it was ten years ago. With the demand that parents invest more in the education of their children, families are making choices on who is to be educated. Poverty and gendered assumptions about women are influencing parents', particularly fathers', decisions on whose education, a boy's or girl's, is worth investing on. Girls are denied educational opportunities and some have been sent to work as child labourers to help feed their families or even educate their male siblings. As Wausi observes, the situation of women's education is rather pathetic.

Wa: It is a bad thing we are so poor, I think if there was more help from the government in terms of facilities or education, like these days kids in school are not supplied with any textbooks in schools. The only thing the government gives to school children is the free milk There are no textbooks, exercise books, pencils. In our time, much as we were poor, we were supplied with textbooks, exercise books and pencils. If you want to read a book today, you have to buy it. I think now, given the population has increased, I think there are fewer women in the rural areas who are making it than there were those days. I think ten years ago there were more girls making it through the education system than today, particularly from Kilome.

MN: Yes and you are not the first one to say that. It is not getting better..

Wa: It is getting worse, there is a lot of poverty (Interview, September 1994).

Mutheu concurred with Wausi that more girls are not getting education, particularly in the rural areas, because of the structural adjustment policies through which the government has reduced its spending on education. This strategy has forced parents to invest heavily in their children's education. 
MN: What about school fees these days?

Mu: These days school fees is an issue. Before, it wasn't such a big issue. It was manageable but now when they get to Form 1 the money involved is quite a lot. These days a parent might be forced to decide who to take to school and who not to. I would say that these days, there is a very high possibility of parents doing that. They are making choices and often they don't favour girls. A few years ago, school fees was not an issue (Interview, September 1994).

School fees became a big issue with the introduction of the cost-sharing strategy in the early 1980s which meant less government spending on education and more parents' contribution to the education of their children. This strategy was imposed on Kenya by the World Bank to help the government deal with its deficit which, the World Bank argued, expenditure on education contributed to substantially. There appears to be no definite amount as to how much parents are charged for the education of their children. Official figures of total costs of education show that the pre-primary level of school is the least expensive costing 600 Kenya shillings year with the government contributing 2 percent of that amount. The primary level of education costs Ksh.2,100/= (70 Canadian Dollars, I CDN $=30 \mathrm{Ksh}$ ) per year with the government contributing 44 percent of that figure and Ksh. 7,500/= per year for secondary level of education with the government contributing 27 percent of that amount (Ndegwa Report, p. 172: Source: World Bank and GOK, Financial implications of programmatic changes in Kenya's education system 19902000).

Although the official costs of education seem affordable, the reality is that the tuition and non-tuition fees charged at all levels of education are higher than the official figures quoted. Parents with secondary level children indicate that fees in secondary schools range from $9,000-20,000$ Kenya Shillings per year $(\$ 300-700 \mathrm{pa})$ or more. These 
fees are highest in the first year of secondary school, particularly for those students who, in addition to buying school uniforms, have to buy bedding, a charcoal/paraffin stove, utensils and other necessary boarding items depending on the school.

The high school fees charged at the secondary level are quite unaffordable for most parents. School fees have therefore become a barrier to children's access to educational opportunities particularly at the secondary level. This situation has forced parents to make choices on who is to be educated and in which school, a harambee day or government-maintained boarding school. When parents have had to make a choice between investing in the education of a boy or a girl, the choice is clear.

\section{Traditional Preference to Educate Boys}

Traditionally in Kenya, sons have tended to be valued more than daughters. Even in these modern times, most monogamous marriages have turned out to be polygymous ones if the first wife has "failed" to bear a son. Son preference in Kenya can be observed right from the moment of birth (Eshiwani, 1983). This attitude seem to influence the educational opportunities that are made available to boys and girls.

Since the introduction and development of formal education in the twentieth century, women's education has lagged behind that of their male counterparts because gender was used by the missionaries, colonialists and the local indigenous people as a criterion for allocating educational and employment opportunities in Kenya. In the case of the women of Kilome, the excerpts of the women's stories showed that their fathers chose to invest in the education of their brothers rather than in their own education. The educational experiences of Kilome women of different ages showed the persistence of 
son preference in the allocation of resources in the acquisition of educational opportunities. Mulee, for instance, talked about her experiences of schooling as follows:

Mu: I really did not attend school well.. I used to be sent home so often and at Standard 7 I left school because my younger brother caught up with me and I was asked to stay at home to let him to be educated. I used to be made to miss school many times and I would be asked to repeat classes, eventually he caught up with me and I was asked to leave school because my parents couldn't afford the school fees (Interview, July 1994).

While the introduction of formal education along gender and racial lines has had a negative impact on the education of women, parents' preference to invest in the education of their sons has exacerbated gender inequities in accessing educational opportunities. The fathers' preference to invest in the education of their sons, rather than in the education of their daughters, is influenced by precapitalist beliefs about marriage and family. Among the Akamba, for example, families were and still are patrilineal and family descent is still traced through the male side. Property is still acquired through inheritance and it is only sons who can inherit property as well as the responsibility of the family in the father's old age or when he dies (Muthiani, 1973). Similarly, in the modern context, education is seen as an inheritance to be acquired by the ones who will take the family's responsibility and carry on the family name. Therefore, if a family disposes of its property such as livestock and land to educate a son, he is expected to take responsibility of the family and look after his aged parents when he finally enters the formal employment sector. 


\section{Assumption That Girls Will Get Married}

Among many African peoples, marriage is seen as a focus of existence, a duty, a requirement of the corporate society, and a rhythm of life in which everyone is required to participate (Mbiti, 1990). A Mukamba family continues to be patrilocally extended and women leave their homes to go and establish "their own homes" at their spouses' homes.

The interplay between high monetary costs of education and the potential of adolescent girls to become mothers limits educational opportunities made available to girls. Many rural families with non or limited income-generating opportunities are forced to sell their property, usually land and livestock, to educate their children, particularly at the secondary level of education. Women from Kithumba and Kyandue villages and those from Salama town note that very few men dispose of their property, especially land, to educate girls because of the gendered cultural assumptions about womanhood.

Traditionally land belonged to the clan or family but not to individuals. Land was used communally and was not considered a property to be inherited like livestock. However, the land registration policy introduced by the colonial administration and reinforced by post-colonial land policies stipulated that land be registered in the name of the head of the household who was assumed to be the man. Under this policy, a man in whose name the land is registered owns the land and controls the products of that land. He is the only one entitled to make decisions on the land. Land has become a very valuable property that has increased its value with population boom. It has become a scarce commodity and a source of serious family disputes. Payment of secondary school fees is one of the few reasons that a family would consider selling a piece of land. Most 
men, however, will not dispose of their land to educate a girl because girls are considered "transient" members of the family. It is assumed that when girls mature, they will get married and leave their families. Most men feel that investing in a girl's education is an unwise move, a precarious venture because a girl may become pregnant and leave school and/or she may get married and leave her family.

Ngina notes that many fathers feel that it is not worth investing heavily in a daughter's education since she will get married and her education will benefit her husband's family that did not invest in her education.

MN: Are most girls from Kyandue achieving a good education?

$\mathrm{Ng}$ : Not really. I think the same beliefs that existed long time ago are still lingering with us. When a man educates his daughter, he feels that she will take that "profit" (vaita) to somebody else's home. Some people still feel that if they educate their daughters, they will leave and get married. That is not true (Interview, July 1994).

Meli, too, points out that some girls' educational opportunities are limited because they are expected to get married.

Me: I feel that girls do not stay on in education because many parents argue that they shouldn't spend money on educating girls because they will get married but these days there isn't a girl and boy. All children are the same and, if the one who you see has an interest and puts effort in school, you should educate that one without discriminating. All children are the same and any child who is interested in education and works hard should be encouraged and supported by all means (Interview, July 1994).

Manduu, who is over 50 years of age, has not seen any man sell land to educate a girl.

Ma: I have not seen men sell land to educate a girl but they sell land to educate boys. This is not a good way of thinking because even if the girl eventually gets married, when she gets a job she will not forget her parents. Also, she does not have to get married and, more so, even if she gets married, she will help herself and her family with that knowledge you gave her. And that for a woman is a big benefit because a woman will never go and spend her money on alcohol she will always take it home and support her children. ... Her children are her first priority (Interview, July 1994). 
The gender discrepancies in investing in the education of girls and boys are widespread and women from all the sites reiterated that it was extremely hard for men to dispose of their land to educate a girl. Many women from the other sites agreed with Kilome women that:

It is very hard for men to sell their land to educate girls. They wouldn't agree. If there are any they are very few and we have not heard of one. They [men] will sell land and cows to educate sons (women in a chorus). Men can sell all the cows and leave the barn empty to educate their sons (Kithumba women's self-help group, July 1994).

Therefore the increasing high cost of education is limiting girls' educational opportunities particularly at the secondary level. Because of the physical and material demands of the education system, parents dispose of their property (land, cows) to educate their children. There is still a strong belief that a woman, no matter how much education she gets, will eventually get married and move out of her home and take all that education to benefit her spouse's family. The question that the parents ask is: What happens if the family disposes of their land to educate their daughter who, after acquiring the education and a good job, gets married and leaves the family, or worse still, she drops out of school because of a pregnancy? Women, however, note that gender relationships in marriage change to the benefit of the woman if she is educated. As Ngina points out:

If your daughter has an education, she does not have to get married. If she does get married, she doesn't have to get married in the real traditional meaning (ti kutwawa ni kutwaana), it is no longer the getting married but the man and woman marrying each other. My desire is to have my daughters educated more than the boys because they are more empathetic than the sons. If your daughter is not educated and therefore has no job or means of earning her own income,, she will have to struggle with her husband to get anything (support) from him to support herself and her parents (Interview, July 1994). 
Although Ngina feels that the pressure to get married may be eased by being educated, the experiences of two of the professional women who participated in the study indicated otherwise. Koki notes that her parents have tried to pressure her to get married. They have sought suitors for her.

Ko: I remember there was a time that my mother sent for me to go home. When I went home she told me about this widower who was like double my age wanted to marry me. She said that his parents had come to see them (her parents) and were interested in me. I was so angry with her. How could people come to my parents to ask for such things.. and the age difference and the man himself! I didn't like it at all. I told my mother that I was capable of finding myself a man if I really want one (Interview, June 1994).

Koki's parents nonetheless expect her to contribute to the family's welfare more than her sisters who are married. The parents want her to contribute money towards family projects but she knows that she will not inherit any of them. She points out that her married sisters are not asked to contribute because the parents argue that those married have their "own homes" to worry about. She wonders why her parents do not understand that she is a single mother and has the sole responsibility of her daughter.

Wausi, another single parent, feels that she too has experienced a lot of pressure to get married. She feels that although she would like a partner, she shouldn't be rushed to find one. Akamba culture expects all girls to ultimately get married and have their own "homes." Muthiani (1973) points out that a home, as the Akamba saw it, is a family which comprises parents and their offspring or the nuclear family. A home also included grandchildren. It is therefore understandable why women who are not married and have children are not considered as having "homes." The cultural expectation that girls' should ultimately become wives and mothers has become an impediment to girls' education. 


\section{Girls' Potential Motherhood}

Women from Kilome division note that there is an increase in the number of girls leaving school because of pregnancies, particularly at the senior primary and secondary levels of education. Kilome women identified this as one of the reasons why men are hesitant to invest in the education of girls. Girls who get pregnant in school are expelled from school with little possibility for re-entry into the formal education system. Girls are doubly victimized as a result of pregnancy. When a girl leaves school because of pregnancy, the repercussions of her deed could be far reaching. In extreme cases, fathers might refuse to educate the other female children and blame the mother for her daughter's "bad behaviour." Mwelu described the situation quite eloquently.

Mw: There are many girls dropping out of school due to pregnancy even though it seems that nowadays girls have learnt other ways of avoiding pregnancy. There have been very many such that out of $\mathbf{4 0}$ girls in a class, about 20 leave school because of pregnancy. Those who "persevere" to the end are quite few, not many. That is one form of failure. If one gets a child while in school, that ends their education because one cannot be a mother and a student at the same time. You cannot manage both. For others, their fathers are very angry when their daughters get pregnant and feel like sending the daughters and their mothers out of the home. Others refuse to educate daughters who come after the one who left school because of pregnancy. Some parents stop paying fees for all their daughters because of one girl's mistake because they do not want to waste their money. That's it. If a daughter gives birth, she disheartens her parents. Some parents as I said refuse to pay school fees for all the other daughters and maybe this daughter was not going to have a baby like her sister since all children cannot be the same. Some parents fail to understand their daughters because some girls who give birth don't do so willingly. Sometimes they don't really know what they are doing when they get involved with the boys (Interview, July 1994).

Mariya's two daughters left school because of pregnancy. These girls were not able to reenter the school system. The pregnancy of the two girls undermined Mariya's ability to 
bring up her daughters accordingly. It is not surprising that Mariya did not want to talk about what happened to these girls.

MN: Are any of your children in secondary school?

Ma: I have 10 children. The first two left school before they completed secondary level, they were defeated and they are married now.

MN: What do you mean by "they were defeated"?

Ma: Why, they were defeated by school means that they went through the wrong path.

MN: Meaning what? I really don't understand what you are saying!

Ma: They got pregnant and because of this they couldn't go back to school.

MN: Could you have agreed to look after their children so that they could return to school? (Interview, July 1994).

Ma: (Pause)

Nzula, a friend of Mariya, felt that she had to answer this question for Mariya. She had the following to say.

Nz: You see.. let me answer that one for her.. that is the story we were telling you.. that is how it becomes.. now you a woman (mother) you want to educate this girl, you want to take her back to school and your husband tells you that "because your daughter gave birth, she can not be taken to school" and you have no money. So what do you do, tell me? (Interview, July 1994)

The interview excerpt shows that Mariya was not very comfortable to talk about her daughters' pregnancies. Her feelings are understandable because, when a girl gets a baby outside wedlock, the mother is blamed for not having taught her daughter how to behave and that illegitimate children are not welcome in the homestead. Often, the father directs his anger at the mother and the daughter and, in many occasions, the father asks the girl to go to the home of the baby's father. Pregnancy tends to mark the end of formal education for the girls involved. Investing in a girls' education is therefore considered a risky business. As Kadongo observes,

$\mathrm{Ka}$ : Girls from this place don't stay in school long enough because many people, like parents and especially fathers feel that educating a woman is a waste of their money because they say that this girl will go to school and will leave (quit--aemwe in kisomo kii) before she completes to get married or because she is pregnant. 
most girls tend to get caught up in worldly pleasures. Because of this they prefer to educate boys. I don't know why they take it that way (Interview, August 1994).

Maria, too, feels that there are too many girls dropping out of school to get married and also because of pregnancy. She also states that girls value marriage more than education and tend to jump at any opportunity to get married. It is very rare to meet a woman who was never married. Although roles within marriage have changed with time, there is still that strong message sent to girls that when they are of age they should get married and have their own "homes." A single woman is seen as though she is incomplete. Besides getting education from schools, mothers try to give their daughters skills related to motherhood and wifehood. Maria has experienced the pressure to go back to her husband even though her marriage was both physically and emotionally abusive. One elderly woman whom Maria calls "mother" (since she is old enough to be Maria's mother and also Maria's mother is deceased) has repeatedly asked Maria to go back to her husband. Maria does not want to go back to her husband or to get married to anybody else. She notes that when a woman gets married, she is trapped and it becomes impossible to re-enter the education system (particularly if she hadn't completed secondary school) or search for paid employment. Maria observed that:

They (girls) seem to be interested much more in getting married. I ask them why it is that you want to get married and they say it is as though it is a must for a woman to get married. I ask them what about working? They say, it is a must to get married but not a must to work. Also, some girls leave school because of pregnancy and their parents take it so badly such that they ignore them and sometimes mistreat them and they don't give them any help and because of this neglect, they (the girls) decide to get married to anybody who they meet first and chances are they get married to the wrong person. And when they get married, many men will not allow you to go and look for a job because that is considered like becoming a loose woman and so you are stuck at home giving birth and doing the donkey work (Interview, August 1994). 
The assumption that women will become promiscuous if they work outside the home limits their participation to activities in the private sphere.

\section{Responsibility for Sex education}

Unwanted pregnancy is one of the factors that limits girls' educational opportunities. However, as Wausi, one of the professional women, points out, there is no one educating girls about their sexuality. Traditionally, grandmothers discussed sexuality issues with their granddaughters. Youngsters learned about sex in the traditional dances that they attended. The coming of the missionaries marked the end of these traditions. Wausi points to Christianity or religion as the major barrier to the possibility of addressing sexuality issues. Wausi had the following to say:

Wa: I think the biggest problem is that because of this "witikilo" or Christianity, I keep telling you about. People avoid the whole issue of talking about sex and yet it is responsible for a lot of the problems. I mean so many girls drop out of school when they are in primary and in secondary school because of pregnancy.. you just hear so and so's daughter is pregnant, people want to avoid issues like telling their daughters that you can get pregnant, they also want to avoid issues like telling her that "you know, if you really must do this you better do abc" and of course there is also the other moral from the Bible like "you are single you should not be having sex." I mean, like I found that when I got to college suddenly you are in a relationship and you can't even make a decision about getting contraceptives because there is a part of your mind that tells you, "God, the minute you do that you will start saying yes to every man and you are just as good as a "pro" (meaning prostitute). And I think that happens a lot in common, it is like here you are into something and every other person is doing it and yet you know a lot of them are in very stable relationships but you can't just bring yourself to make that decision. I mean it is tipped in a lot of moral issues that a lot of us have not sorted out by the time we get to college or even whatever time we become sexually active, yet..

$\mathrm{MN}$ : There is denial?

Wa: There is some denial also ..

MN: It is like they are seeing their daughters get pregnant and they don't talk about it, let's close our eyes. 
Wa: The good girls are the ones who get through it. Yet there are a lot of good girls who make a small mistake. I think it is an issue that needs to be addressed very cautiously and seriously and have a lot of time devoted to constantly making young people aware of the dangers of.. and all that it is involved. I don't know. It frightens me about my own daughter (Interview, September 1994).

Teenage pregnancy is a concern of every parent, particularly mothers who are held responsible for teaching their daughters morals around sexuality and the consequences. As Wausi points out, the issue of sexuality is complex and mothers are not sure how to address it in the modern context. In the precolonial contexts, young people learnt acceptable norms through grandmothers and age-group rituals such as circumcision. Mothers are apprehensive of exploring the technological choices for controlling reproduction with their daughters because it would be equivalent to promoting promiscuity. Abstinence is the most preferred method of contraception, but the reality is that most girls are sexually active.

Women in the village expressed the need for girls to be "well behaved" to avoid getting pregnant. Beth noted that:

Be: Yes it is true that we parents do not talk about sex with our daughters. We behave as if we are scared of each other and somehow we hope they learn about it in schools or somewhere else, I don't know where. The problem is that we parents are not very close to our daughters.. I don't know whether that is the reason but it is just so hard for you as a mother to talk to your daughter about such things. You see, in the early days our grandmothers used to talk to us about what would happen if we slept with boys (Interview, June 1994).

Mariya pointed out that mothers need to develop a close relationship with their daughters

so that the daughters can feel free to discuss their sexuality with them.

Ma: I don't know how we can do it but I think it is very important for us mothers to establish a good relationship with our daughters while they are small so that they can feel free to tell us what is happening in their lives. Most of the times, we never even know that they have started having their periods before we find they are pregnant and then you are in trouble with your husband who thinks that you 
should have known what was happening and prevented the pregnancy from taking place (Interview, July 1994).

The dilemma that most parents face is how girls should be told about using contraception without compromising assumed standards of morality. Also, there is concern about whether schools should be teaching girls about sexuality and what should be taught in the classes.

Women and girls are being held solely responsible for childbearing and childrearing. However, it is important that both boys and girls are made aware of the consequences involved so that girls are not doubly victimized for getting pregnant. Of importance too are the circumstances that girls become sexually active. Often the men involved are adults who coerce the girls into sexual relationships which result in pregnancies. Girls need to be taught about their rights and provided the space to discuss such abuse without being blamed for provoking it.

\section{Poverty}

Underlying the gendered cultural assumptions that limit girls' educational opportunities is poverty. Poverty among rural families is a major limiting factor to the education of girls in Kilome division. In a society created by the colonial administration, that is divided between a comparatively small urban elite and a large impoverished and mostly rural population, families are having to make decisions and choices of who is to be educated based on gender. Women form over $78 \%$ of the rural adult population. In these impoverished conditions, women in the neocolonial era have limited access to resources and have little control over resources that the family owns. Women are the 
poorest of the poor since even poor men have poorer wives and children (Vickers, 1991). Women are, however, well aware of the importance of girls' education and are committed to providing their children with educational opportunities but as Nzula, a participant in this study, points out, most women lack the resources or the economic power to afford the high fees charged in schools specifically at the secondary level. Nzula put the dilemma that women face succinctly:

If you are told that there is no money to educate your daughter, what can you do to push the child ahead, if my husband comes and says there is no money and I am not working and I have no authority to sell land. You see men are the ones who sell land. I can't even sell land. What can I do? (Interview, July 1994)

Colonial and postcolonial development policies shifted the control of communal land to individual men assumed to be heads of households. The shift has meant that men control the land and the products of it and that women's access to land is mainly through spouses or male relatives. Market-oriented land policies have had a negative impact on rural poor,, the majority of whom are women and their children. As Vickers (1991) argues, the recession, the debt crisis and structural adjustment policies have placed the heaviest burden on poor women, who earn less, own less and control less. Women care for children, the aged, the sick, the handicapped and others who cannot look after themselves. They service the household with food, cleanliness, clothing and in many cases water and fuel. When rains fail and food prices rise and wages fall, a woman must spend more time finding ways to satisfy her family's hunger, often eating less herself in order to feed her husband and children. Women's activities are labour intensive and mostly unpaid.

Women in Kenya have limited sources of income. Female participation, as a proportion of modern wage employment, was $22.1 \%$ in 1991 with most of the women 
concentrated in traditional female domains characterised by low pay, poor working conditions and no benefits (Republic of Kenya, Women's Bureau/SIDA project, 1993). Low participation of women in the formal employment sector is a consequence of colonialism. Colonial policies such as (a) development of a formal employment sector in the urban areas with high paying jobs for those educated, (b) the need for a semi-skilled African cheap male labour, and (c) the provision of education and employment opportunities along gender lines are factors that have limited rural women's participation in activities designated "significant economic activities." Rural women's concentration in activities designated as "non-economic" has impeded their struggles to afford their children educational and economic opportunities.

Poverty is pervasive in the rural areas such as Kilome division. As Mutheu observes, poverty and famine have made it almost impossible for parents in this area to afford their children educational opportunities particularly at the secondary level.

Mu: First, families in Kilome have to buy food from the shop, the rains are bad and we have overpopulated the land. The fact that food has to be bought competes with school fees.. the issue is to survive first and think about school later. You see our area has a lot of problems. We have very few girls' schools and others go to far away schools and there are many problems with this too. Bus fare has gone up and you have to buy so many things because these days they go with so many things, bedding, besides soaps and school fees and especially to go to Form 1 if you as a parent want your child to be a bit comfortable, you must have at least 20,000 Kenya shillings [CDN \$700] because you have to buy all things including a basin for bathing and there is also a lot of theft (laughter). In our days we used to lock up things in lockers or in our suitcases. But these days how do you lock up your mattress in a box? (laughter) or your blanket? Your child comes home and tells you that the blanket has been stolen. There are so many problems and the kids have become small criminals (laughter) because those days we just used to have petty thieves but these days you find kids who steal everything and anything. If you open their suitcases (boxes) you find spoons and these days they are just taking the things from you. The reports that are coming out of schools are scary. This is because there is a lot of property-personal property in schools (laughter) in the dormitories and so the risks are higher. All that burden is on the parent because they are the ones who hear these problems first. And these problems can only be solved with money (mbesa) not with maize (mbemba). 
Somebody else had written in the paper that Form 1s look like civil servants when they are going to school because they carry a lot of things, mattresses, blankets, basins, stoves and a lot of money to pay school fees and so the parent has to take that child up to the school because thieves and conmen target these children and so the parent has a lot of work (Interview, September 1994 emphasis added).

Many rural families live in conditions circumscribed by poverty and this has influenced girls' educational opportunities. Kamene and Wanza attest to the impact of poverty on their education. Assertions such as the following give a sense of the reality of women's lives. "I left school in Standard 3 because of poverty." "I went up to Standard 4 and left school because of poverty, we lacked resources." "Do you know how much hardships we endure!" "There is a lot of poverty here." "Do you know that it is because of poverty we are so much behind! Everyone wants to educate her children/daughters but if there is no money how can you give them an education"? (Musili, Wanza, Kamene and Beth, Interview, July 1994).

\section{Conclusions}

Women identify the high cost of schooling as a major barrier to girls' education. They also identify gendered assumptions that limit the allocation of resources to girls and deny them access to meaningful educational opportunities. The women point out that fathers minimize their investment in the education of girls on the assumption that girls will get married and will not take the primary responsibility of their families' welfare.

However, the women of Kilome are determined to offer their daughters meaningful educational opportunities to enable them to participate in the public sphere as do their male counterparts. These women firmly believe that education opens doors and offers the opportunity to break the poverty cycle. The women have taken new roles and challenges 
of providing their children with education and economic opportunities. In addition, they continue their roles as food producers, cash crop producers, childrearers, care givers and active participants in women's self-help groups and other community affairs. Women's labour is also required for the numerous "development projects" that have been initiated by the government and development organizations in the rural areas which Feldman (1983) argues have little potential for improving the living conditions of rural women. However, the women's agency is evident in their articulation of their experiences, those of their children and in their active participation in resisting, restructuring and/or transforming their society. 


\section{Chapter 7}

\section{Intensification Of Women's Labour To Educate Their Children}

\section{And Its Implications}

In this chapter I examine Kilome women's economic activities and the intensification of their labour as they pick up new roles and challenges as intervention agents for their daughters' education in Kenya today. The women are convinced that the education of women is important and are engaged in a variety of activities to enable their children, and daughters in particular, to acquire the educational opportunities that were denied them because of cultural, social, economic and political factors. First, I discuss the importance that women attach to educating their daughters. Secondly, I examine the women's inability to depend on husbands for their daughters' education. Thirdly, I examine the intensification of women's labour as they engage in a multiplicity of incomegenerating activities to provide opportunities for their children's needs in a gendered economy. Finally, I examine the limitations of women's activities in making educational opportunities available to their daughters and the implications of the women's intensification of labour to their health, to girls' education and to the welfare of the women's dependents (children, the aged and the sick).

\section{Importance Women Attach to Educating Daughters}

Kilome women who participated in my study noted that their daughters and the majority of girls in Kilome division are leaving school without the educational credentials 
capable of affording them paid employment or reliable/dependable income-generating activities. Both in our group and individual conversations, the women repeatedly linked education with paid work. The women stressed that there were great benefits in educating a girl. They noted that it was very important for their daughters to be economically independent to deal with their children's, parents' and personal financial problems without having to ask for money from their spouses.

The women desire for their daughters to get as much education as possible because they know that in present day Kenya, there are no employment opportunities for holders of primary school level education. When I asked one group what kind of education they would want for their daughters, the women responded in a chorus,

We want our daughters to study hard as you did, we want to see them employed with an income and having their own property. We want to see them self-reliant (meekwatie). If you had not been educated would you have been able to assemble us here? (Kithumba Women, July 1, 1994)

The women believe that education would enable their daughters to challenge the institutionalized pattern of gender relations which involves inequalities of power, sexuality and resource allocation favouring men over women (Scott, 1990). To these women, an educated woman would be able to find employment and (a) support her mother, (b) support her family and own property--be self-reliant, and (c) make her marriage choices.

\section{Support for Mothers}

The women bank on the education of their daughters as an investment from which they will reap benefits when their daughters enter the formal employment sector. They stress that daughters are more empathetic than boys to their mothers and would support 
their mothers financially. For instance, Rachel likens education to a fruit. She notes that, if her daughter gets an education and a job, she will not let her mother suffer. Indeed, Rachel will forget all the awful experiences she has had as a married woman.

MN: Is education valuable?

Ra: It is very important and valuable. It is our "fruit" now because if you look around, the household that has no education, they have no "fruit" to eat. The way I have seen education in Kenya, it is the fruit of Kenya because if my daughter gets education, I know that I would forget those awful experiences I had and the struggles that I had to go through to educate her. I feel that education is so important in my life.

MN: What about a girl's education?

Ra: A daughter's education.. what I see is that girls are more empathetic and are merciful. Like now I told you that my mother has a lot of things, at least more than myself, but whenever I get something I always feel that I should give her some of it because of that mercy. Men are not like that (Interview, July 1994).

Kadongo, too, feels that educating girls is important because girls would not neglect their parents when they get employment. Kadongo also emphasizes the economic power that education accrues to women through employment, consequently enabling women to accumulate capital to purchase property.

MN: Is educating girls important or is it worth it?

Ka: Yes, it is very important. These days $I$ think it is better to educate girls because they do not neglect their parents. Educated women are supporting their parents a lot.

MN: How would education have helped you?

$\mathrm{Ka}$ : What are you saying! It would have helped me a lot. For example, I would be able to do my own things. I would be working and I would be able to help my parents because they are the ones who educated me. I would have been able to build a house for my children. Right now, I cannot afford to buy the corrugated iron sheets that I need (Interview, July, 1994).

Ngina from Kyandue feels that she will benefit more from the education of her daughters than that of her sons. She too notes that:

$\mathrm{Ng}$ : My desire is to have my daughters educated more than the sons because girls are more empathetic than boys. Sons can refuse to give their own mothers things and take them to their mother-in-laws, do you know that? But a woman would not 
do that to her mother. It is very hard. A daughter would want her mother to have good things. She would support her mother financially even if she is married (Interview, July 1994).

Kambua, from Salama town, too, concurs with the village women about the importance of women's education. She points out that it is important to educate women because, if a woman starts working, she will support her children and her mother. In her case, she is trying to support her mother with the little money that she earns as a bar maid.

MN: Do you think education of women is important?

$\mathrm{Ka}$ : Oh please (yii mwa ki maana) it is very important because women are the ones who know their children, they are the ones who take care of their children and mothers. Like in my family, I am the only one who supports my mother, my brothers don't care at all about her. I send her money twice a month but the boys don't do that. Personally it (education) would have been very important. You see if I had gotten an education, I wouldn't be working here. I wanted to become a nurse. Nurses don't suffer the way I suffer here.. nursing is much better. They can do things for themselves. Like you see sometimes if a woman is married and there is no cooking fat and other little things like that, should I be writing letters to him (imaginary husband) in Nairobi to tell him that we have no cooking fat? I should be able to do some of these things with my own money or buy the children school uniform and take my children to hospital if there is need for that. I think it would be important for me to do things for myself and education would have made that possible (Interview, September 1994).

These interview excerpts show that parents still believe that education ensures individuals reasonably well paid jobs in the urban areas. Sons, traditionally, are expected to carry over the family's name and the responsibilities in it. Such responsibilities include ensuring that their aging parents are given adequate care. The excerpts, however, show that mothers no longer think of sons as the only ones who can support them in their old age. Mothers believe that they would benefit more from their daughters' prosperity than from their sons. 


\section{Support Own Families}

Manduu points out that it is also important to give girls education because when they get a job, their families, particularly their children, would be the first priority. She claims that men are likely to spend their money on unimportant things like alcohol. Manduu feels that educating girls is an invaluable investment that warrants even the disposal of land.

I have not seen men sell land to educate a girl but they sell land to educate boys. This is not a good way of thinking because even if the girl eventually gets married, when she gets a job she will not forget her parents. Also, she does not have to get married and more so, even if she gets married, she will help herself and her family with that knowledge you gave her. And that for a woman is a big benefit because a woman will never go and spend her money on alcohol, she will always take it home and support her children. . . . Her children are her first priority (Interview, July 1994).

Kilome women feel that education has the potential to open many doors for women. The most important option education affords women is the opportunity to participate in the formal employment sector. The women see how education has enabled men to enter the formal employment sector while the women's lack of education shut them out of this sector. Women earn their money the hard way but spend it all on their families while some men spend their money on individualistic ventures or habits. Wanza, for instance, is concerned that her husband has not made the family his first priority. She notes that, if she had received an education equivalent to that of her husband and had a similar job, the family wouldn't be experiencing the financial hardships they are undergoing.

MN: Is the education of women important?

Wa: Very much so (yii mwa). I'm sure you know that girls are more empathetic with their parents than men. Men can get their salary and go and spend it with other women outside and forget their own families and parents. Like yourself, 
would you let your mother suffer? For example now, if I had education and maybe the job that my husband has, I would be able to take care of my family. You see, I will not go out and squander my salary with anybody when my family is going without food and education. Like now I need to build a house and I do not have the money. But if I was the one working, I wouldn't take that money and spend it outside the family.

MN: Does he drink alcohol?

Wa: Sometimes he does but not always (Interview, August 1994).

Mulee, from Kithumba, feels that if her father had allowed her to get an education equal to that of her brother, she would be working or having a regular income and supporting her family just like her brother supports his family.

MN: Let's say you had had an education, how would it be?

Mu: If I had received a better education I think I would be better off (nithiwa nikavala). I would be doing something (meaning work), I would be sure that at the end of each month I have a certain amount of money coming. I try to look for money that I am not sure I will get. I don't have a definite deal with anybody (kyathi na mundu kana akanenga mbesa). You just go out to look for money depending mostly on luck trying to see if you'll get anything. If I had the education my brother got, I would be able to educate my children without these difficulties (Interview, July 1994).

The interview excerpts show that women feel obliged to take responsibilities over the welfare of their families. These responsibilities require the women to have reliable sources of income. However, the income-generating activities that the women are engaged in are precarious and they perceive education as capable of affording women, and their daughters in particular, more reliable income opportunities to meet the needs of their families.

\section{Making Marriage Choices}

The women see education and its provision of employment as capable of providing girls the ability to make choices in life including choosing to get married or remaining 
single. The women note that marriage is no longer a solution or an alternative for girls' education. Indeed, Meli points out that marriage these days is problematic. Women cannot expect to be just their husbands' helpers. Women need to enter in a marriage relationship knowing that they can take care of their children. For this reason, many mothers are concerned about their daughters getting married when they are not capable of taking care of their children. Meli is concerned about her daughter who left school in Standard 4 and got married. She points out that her daughter is suffering and she would not encourage her other daughters to get married. She asserts that marriage is not a solution if the woman cannot take care of her children. A reliable income is a prerequisite for a woman's selfreliance. The women point out that education and training opportunities increase employment opportunities for girls which are crucial to women's economic independence (Ngina, July 1994). They desire that their daughters get education and paid jobs because the other incomegenerating opportunities available in Kilome division and neighboring divisions are not reliable. The women have had to "sacrifice" themselves in order to have some income to educate their daughters and look after their children. They do not think their daughters would be able to engage in the type of strenuous work they do.

Me: My daughter can see how I struggle to get school fees for her. I really want her to get an education. I don't want her to leave school and get married like her sisters. MN: Why?

Me: Getting married these days is a problem. I am not encouraging her to get married because her elder sister who got married after Standard 4 is having a lot of problems. She is always coming back home from her husband's house, she is not comfortable. I would rather she got educated and become independent, not to depend on a man. I tell her to work very hard so that she can get a good education and a job to help me and herself too (Interview, July 1994). 
Eighteen year-old Munee, a high school student had the following to say about the work that her mother does to support them and also on marriage.

MN: Which Form are you now?

Mu: I am in Form 4 and I will be sitting for my university entry examinations in November.

MN: What do you see yourself doing after completing your secondary level?

Mu: I want to go to college and train as a police woman.

MN: Then what do you do after that?

$\mathrm{Mu}$ I will work and do my own things.

MN: Do you think you will get married?

Mu: Who? Me? I am not thinking about that now. I don't want to think about that now. Don't you see how those who got married after Form four are suffering? It is too tough particularly if you are not working and you have nothing that is yours.

MN: Well, you can cultivate his plot and plant food crops just like the other women who don't have paid jobs. Your mother has been able to do a lot for you that way.

Mu: Do you think it has been easy for her? It is very tough She works so hard throughout the year and only gets to rest when she is sick. I don't think I can do that, it is just too hard for me or for any girl of my generation (Interview, September 1994).

Ngina points that when a woman is educated, she does not have to get married in the traditional sense. She notes that it is no longer mandatory for a girl to get married if she is educated.

If your daughter has an education, she does not have to get married in the real traditional meaning (ti kutwawa ni kutwaana). It is no longer the woman getting married but the man and woman marrying. My desire is to have my daughters educated more than the boys because they are more empathetic than the sons. If your daughter is not educated and therefore has no job or means of earning her own income, she will have to struggle with her husband to get anything from him (Interview, July 1994).

Nduki, who lives with her two sons in her father's compound, feels that marriage is not a solution even though her father wants her to get married so that she can leave his compound. She notes that most married women are no better than she is because women can no longer rely on their husbands to meet the families' needs. Nduki blames her father 
for having denied her secondary education which would have provided her a job like her brothers who have found employment with their secondary level education.

I have now lived in my father's compound and I know my father does not want us there. He wants me to get married but getting married is not an easy thing these days. Particularly for people like me with two children you might get married to a man who will start mistreating your children. Yes, getting married is good but marriage has a lot of things or baggage these days and it is becoming impossible. The way I feel now, if only my father had educated me even if I didn't get married, I would be leading a much more comfortable life because it wouldn't be a must to get married (Interview, September 1994).

Nduki is not the only one who has experienced pressure to get married. Koki and Wausi, two professional women, each aged 36 years, too have experienced pressure to get married. Nevertheless, the professional women are not living in their fathers' compounds and do not experience the pressure and desperation that Nduki is undergoing. They are in a position to make choices. If they don't ever get married, they don't have to live in their parents' compounds, they can afford to buy land or a house in the city. Nduki cannot afford this option, which she says would be best for her and her children. Wausi and Koki are both single parents and have daughters aged 10 and 11 years old respectively. Wausi, however, points out that being a single mother has not been particularly acceptable.

The thing is that much as it is very common to be a single parent, it is not exactly accepted. I don't know whether it is because of our religious society but it is like ideally people should only have kids when they are married so like I can tell you much as I really wanted to have a baby when I did, it hit a big blow to my self esteem and ego. It is like somehow, initially I couldn't just strike a balance, it's like I had, I was not completely acceptable.

MN: You didn't feel acceptable or?

Wa: I felt it.

MN: But it was more from within yourself?

Wa: I don't think it was more from within myself. I remember when I got eh.. I mean when I told my parents, yes I still see this guy but I don't want to get married to him. It was like, what? What is wrong?

MN: The assumption was that you should get married to him? 
Wa: You should get married was the assumption but, at that time, anyway I didn't want to get married (Interview, September 1994).

It seems that motherhood is honored only if it is within the marriage institution.

Koki, a 36 year-old registered nurse, midwife and mother of one, has been pressured by peers and parents to get married. She has been introduced to various men in the hope of her finding a marriage partner. Koki is concerned about the preferential treatment that her brothers and married sisters receive from her parents. She points out that her parents are not cognizant of her own family's demands as a single mother and they expect her to invest heavily in the family's projects while they are not prepared to give her rights of inheritance since she is a woman. Koki has educated four siblings through secondary and tertiary levels of education. She feels doubly victimized.

MN: Have you been pressured to get married?

Ko: By who now?

MN: Anybody. Your peers, your colleagues, your parents etc?

Ko: Yes I have been pressured.

$\mathrm{MN}$ : By who?

Ko $\mathrm{My}$ mother has pressured me to get married. She has even found.. (laughter) she has tried to get people for me to marry and peers have introduced men to me to marry and it did not work out (laughter from both of us). Our culture is like that. If you are married you are seen as a good woman.

MN: And what do you feel about that?

Ko: I hate our culture.

MN: Do you feel that you should get married for the sake of satisfying that cultural expectation?

Ko: You shouldn't get married just to satisfy a culture. On the other hand when you don't get married you are seen as a bad woman. One who never got married, without her own home (nde musyi wake).

MN: Own home! What does that really mean?

Ko: You should know better since you are married.

MN: You live in a house in Nairobi what is that to them?

Ko: I have a house of my own but my parents do not recognize that I have my own home, house and a child to care for. They don't. Like there is another day I don't know what was happening at home and they needed money or something. Then I said that everybody can contribute, all of us, the married sisters and the brothers. They said 'no but those ones are married.' They can't ask them to contribute 
anything to support their own parents or the homes where they came from because they are married! I find that strange.

$\mathrm{MN}$ : Do they consider you as one of their sons? Do they ask your brothers to contribute?

Ko: Yes. They ask my brothers to contribute and my younger sister who is single. When they want something, they consider me like one of the men, they ask me to pay for it. But now when it comes to their land, can they divide and give me a piece? No, they won't. They can't. I am just in between. They can't give me their land like one of their sons.

M: Have you asked them about it?

$\mathrm{N}$ : No. In fact you have given me an idea. I will ask them about it next time (Interview, June 1994).

Koki's situation is complicated by the different messages she receives from her parents. At one point they want her support even though she has a daughter to look after, but also want her to get married and have her "own home."

Wausi points out that marriage for her should not mean getting "married to a man" in the traditional sense, but the two getting married to each other. Nevertheless, marriage to her should be permanent because divorce "scars" a woman. She points out that many women marry for material, security and physical support from their husbands and most of them remain in abusive relationships because of their dependence on their spouses.

MN: How has it been being single parent? Has it been tough?

Wa: I think it is only tough in terms of eh.. I wouldn't say it has been tough. Fine, there is a part of my mind that tells me that it would be nice to get married. Presumably I wouldn't marry somebody who would leech on me. So it would be like sharing whatever we have and whatever responsibilities we have. I think a lot of women marry first and foremost for a man to provide security, material and physical, and especially material support to be able to pay the rent and school fees and all that.

MN: And that's not the case for you?

Wa: Support could be an issue because, for example, I think if I was making more money I would certainly take her [daughter] to a private school rather than the city commission school she is in now. Right now, I feel I cannot afford it but then the solution is not to get married and I know it is within my means to get another job and so I will just do that, try and find a better job. Well, so I think the only tough thing or difficulty being a single parent is because.. I mean.. like I think in a marriage, the man has his roles and the woman has her roles and I think when I 
lived with my parents when I got my daughter, I think a bit of the so called man's roles were played by my father and now I am on my own. I mean parenting is a full-time job and I have got my own life to lead, I have a career, sometimes I feel I don't give as much time to her (daughter) as I should. Other times I feel for example right now, I don't have much of a social life myself because I give all my attention to the child. From that point of view that is the only thing that has been really tough but I am looking for a solution to that (Both of us laugh).

MN: Is education very important in all these decisions you are making?

Wa: I think it is very important, there is no doubt about it. If I was anybody else, I think I would have been forced into that kind of subservient relationship and unpleasant relationship if you like. At least now I can make choices (Interview, September 1994).

Wausi notes that she can make choices not only because she has a good education and a good job but because she is also empowered. She feels that many women, some who hold good paying jobs, are still being abused by their spouses. On the issue of getting married, Wausi points out that she can make a choice whether to get married or not and to whom.

Wa: At least now I can make the choices.

MN: You can make choices. You don't have to make those hushed decisions about marriage.

Wa: Yes.

MN: Does education and your career give you the power to make decisions?

Wa: Well, I think fine there is that but at the same time I think there is.. the way we are_socialized, I mean there are so many women who, if you like they have good jobs, good education and they are still abused by their husbands because maybe they have threatened the position of the man in the family. It could be a perceived threat and not a real one. I mean that.. they feel that they should still refer a lot of things to their husbands. You even see women who take their pay cheques to their husbands just to give him that upper hand.

MN: So you feel that there is a lot more?

Wa: There is a lot more.

MN: Women have to be empowered?

Wa: Exactly. Women need to realize that it's not just economic power that gives you that bargaining strength. You've also got to realize that you are an individual and you've got to assert yourself.

MN: But without the economic power..

Wa: Don't you hear the Kambas say that 'so and so is a proud pauper '?(Interview, September 1994 emphasis added).

\footnotetext{
${ }^{1}$ This is an old Akamba saying that means that you can still be poor but retain your dignity.
} 
Wausi points out that economic independence does not necessarily produce a liberated woman. She feels that women need to be assertive in addition to being economically independent. Wausi's observations of family relations are a clear indication that, even though women are working to support the family economically in the public sphere alongside men, familial hierarchical identities have not waned. Indeed, in Kenya, at the legal level, the rights and duties of each marriage partner, and even the definition of marriage itself, is unclear and often controversial (Stitcher \& Parpart, 1988). Whatever the marriage type, a wife has very little actual protection against the main risks she faces: lack of support, lack of child support, and physical abuse. Wausi, however, made it clear that women's rights must be upheld by the women who should live their lives knowing that "a beggar does not have to lose his or her pride and dignity." Consequently, women, no matter how impoverished, should be treated with dignity.

\section{Women's Inability to Depend on Husbands for Daughters' Education}

More and more women have had to take charge of their children's, both boys' and girls', education because (a) they are de facto heads of households since many men have migrated to the urban areas in search of employment, (b) they are single heads of households, (c) there is not enough money in the household, and (d) because of men's preference to educate sons.

Many rural women have become de facto heads of households as their husbands have migrated to the cities to seek employment. These men visit the rural areas at most once a month when they receive their monthly pay. The women are left behind in the rural areas with their children and are supposed to meet their children's needs with the little 
money they receive from their migrant husbands. Women are the ones who enrol their children in the first level of formal schooling. They are the ones who are responsible for the material and physical labour that is demanded in schools. When children are sent home to collect fees or to buy an exercise book, a pencil or school uniform, it is the mother they will find at home. It is not possible to rely on migrant husbands' salary to meet the educational needs of their children. Therefore, mothers' ability to contribute financially to the education of their children, and particularly their daughters is crucial.

Due to changes in the family structure, there is an increasing number of femaleheaded households. Single women who are heads of households receive no support for their children's education from the government or from their children's fathers. There is no law in Kenya that ensures that single mothers receive support from the fathers of their children. Therefore, single mothers are solely responsible for meeting the basic and educational needs of their children. Single mothers like Kamene know that their children's access to educational opportunities is dependent on the success of their economic activities.

$\mathrm{Ka}$ : You see me here I am the only one responsible for the education of those four children that $I$ have. They are all looking at me to provide every single thing they need because I am their father and mother. If my business fails, then all those children sink (Interview, July 1994).

Women from Kilome division pointed out that some men are simply not interested in the education of their children and more so, that of their daughters. Several women pointed out that some men do not consider their families their first priority and therefore, women have to become intervention agents for their children. Wanza, for instance, notes, Wa: For example now, if I had education and maybe the job that my husband has, I would be able to take care of my family. You see, I will not go out and squander 
my salary with anybody when my family is going without food and education. .... But if I was the one working, I wouldn't take that money and spend it outside the family (Interview, July 1994).

Some women noted that even though their spouses are working, the salaries that these men receive are not enough to meet the needs of their families. Such women include Mulee who describes the situation succinctly.

MN: What about your husband, you said that he has been a teacher?

$\mathrm{Mu}$ : Yes, a teacher but don't forget that the household needs exceeds what he brings home. We need well over 10,000 Kenya shillings and he would bring home about 2000 Kenya shillings what does it really come to? Schooling for the girls became a struggle for all of them. And the entire lot of them have had difficulties.. all my children have had to struggle to get an education because of that (Interview, July 1994).

In situations where resources are scarce, we find that men, who control economic resources and their distribution, prefer to invest in the education of their sons rather than that of their daughters.

\section{Intensification of Women's Labour}

Women from Kilome division are engaged in a multiplicity of activities in an effort to create educational opportunities for their children and to improve the living conditions of their families. They are not only food producers and care givers, they are also inventors of a variety of ways to provide the ever needed cash in their families. The women are engaged in income-generating activities as individuals and in groups. They are active as small-hold farmers, domestic workers, waged employees, petty traders and in women's self-help groups.

The women 's income is crucial to the provision of educational opportunities for children and particularly female children. If a woman is not able to take up the challenge 
and serve as an intervention agent, it is clear that more and more children and girls in particular will drop out of school ill-equipped to participate in the changing society. Also, as long as educational credentials continue to be used as prerequisites for paid employment and girls continue to leave school without these credentials, the cycle of poverty that has delineated their mothers' lives will be repeated in theirs also. Mulee has taken up the challenge but it has increased her burden. (Four points . . . . indicate omission between two or more sentences).

MN: What do you do then to educate your children?

Mu: I sell some merchandise in the local market. I go to Nairobi, buy bar soap, paraffin (kerosene) and potatoes and come and sell them. I use the little profit I make to pay my children's school fees... slowly by slowly. ...

$\mathrm{MN}$ : Do you go to the market every day?

Mu: I go three times a week but only in the afternoons because I have to make sure that I have done all the other work that needs to be done. I have to make sure that my plots are ready for planting when the rains begin, I must take time to weed and harvest. I also water the vegetables, then there is the daily work that must be done. You know a home cannot run without water, firewood, somebody has to cook, you know what women do, don't you?

MN: Yes, I do (Interview, July 1994).

The fact that women have picked up new roles and challenges does not free them from their household responsibilities as mothers, wives, food producers and care givers. Therefore, women have to balance their time between all these roles including participation in politically-initiated community development projects where their labour is also required.

All these factors along with the high costs of schooling have necessitated women to engage in a multiplicity of labour intensive income-generating activities. Kilome women's sources of income include (a) employment, (b) sale of property and farm produce, and (c) "petty" business. 


\section{Employment}

Employment opportunities in Kilome division are minimal. There are no big farms and plantations in Kilome division where women can find employment. A few women have had to do casual work in neigbours' smallholdings in order to meet some of their children's basic and educational needs. Such women include Ndunge, Meli and Wayua. Ndunge's work includes helping with household work, digging, planting, weeding, harvesting, fetching water and firewood and cutting napier grass for the cows. She starts work at 8:00 am and finishes at 1:30 PM. depending on the season. Ndunge's desire and commitment to educate her children is exemplified by the multiplicity of income-generating activities she is involved in.

Nd: I want to educate all my children without any differentiation. I really don't look at some as boys and others as girls. What I don't have is the capability to do so. I really want to educate them but I am so poor and I don't know how I will be able to pay the secondary level school fees. Like for those two children who are following each other, one in Standard 6 and the other in 7, I wonder how I will pay their fee with the little money that I earn.

MN: How much do you earn?

Nd: I work for 600 Kenya shillings (\$20) a month and my husband gets about 1000 Kenya shillings about (\$33) as a security man at the market. That helps a little. But the fees are a lot. The first term my son pays around 4800 Kenya shillings and 2nd term is about 3900 Kenya shillings and the third term we pay 900 Kenya shillings. This is for day school only. He sleeps at home and it is far. And you should not forget that this does not include the uniform. With the uniform, it is a heavy load and I am trying to make the best. I am pushing him through. He is now in Form 2 and he is doing very well. His total fees per year are over 9000 Kenya shillings

MN: And your salary is 7200 Kenya shillings per year and that is the same money you use for food and everything else?

Nd: Everything, soap and clothing and I have 7 children (Interview, July 1994).

Although Ndunge is working very hard, she knows that her income is not enough to pay for two children's education at the secondary level at the same time. She has made her daughter repeat classes in the primary level to give her son the opportunity to complete his 
secondary level education. Parents prefer to make their children repeat primary level classes because this level is cheaper than the secondary level. Repetition, however, is one factor which increases girls' drop out rates. Ndunge's two daughters will soon be sitting for their secondary entry examinations. She is deeply concerned about her girls' education after their primary level of education and notes that a mother's economic power is important to afford girls educational opportunities.

MN: What if you as a mother want to educate your daughter and you don't have the resources?

Nd: Then that's when things become bad, that is a tragedy. Like those two of mine (daughters), I know they will both pass and it is possible that the father.. (laughs in a sorrowful way) you know how men are and that men love men and maybe because he thinks that to educate a girl is wasteful because she will take it away. You know they talk like that. Many men talk like that. I can see that my daughter might pass and she is asked to stay at home and the boy is likely to be taken to school. She might also be told to go and work as a house girl and some of that money is used to educate her brother, that is the way it goes and that is a big "crack" (Interview, July 1994).

Ndunge, who left school after sitting for her secondary entrance examinations, knows that Standard 7 education or primary level education offers few economic opportunities. She wants her daughters to have more reliable income-generating opportunities that become possible through higher formal education.

Meli has also tried to educate her children by working for her neigbour as a casual. The salaries are very low and the work is labour intensive. Unfortunately, even though these women who work in their neighbours' plots go home exhausted, they still have to do similar duties in their homes!

Similarly, Wayua, a widow who never got an education and was wed off as a second wife by her father when she was a small girl, has also had to work as a casual to educate her 
children. Wayua did not get an education because her mother who was schizophrenic was not in a position to take care of her. She feels that she must do all she can to give her children educational opportunities.

Wa: You see me here, I have nine children. But I have just two remaining with me at home. The others are married. They went to have their own homes.

MN: Did you educate all of them?

Wa: Yes.

MN: How did you pay for their education?

Wa: By working as a casual worker (ivalua tu ). I was working for a neighbour. I work with my hands (showing me her rough hands). My children's education has become possible that way. I have been working at Mr X's place.

MN: Are you still working there now?

Wa: No. I have stopped working for him now. I don't work there anymore. I work for different people here and there. If a person wants me to cultivate a piece of land or fetch water we agree on the amount to be paid and that's how I earn some money. You see I have fees problems and I have to do those kinds of work. I have educated all my children that way. I have no cattle to sell, I have nothing. I have tried because I do not want my children to loiter, you know how much children without parents suffer (Interview, July 1994).

Although these women are struggling very hard to provide their children educational opportunities, they see the high school fees that are charged in secondary schools as a great barrier. Meli does not see how she will take her daughter through the secondary level of education and she is very concerned about it. Ndunge has made her daughter repeat primary school classes so that she can get her son through secondary school since she cannot afford to pay school fees for two children at the secondary school level. Statements such as "I have one daughter in Standard 8 now and the other I made her repeat Standard 6. I don't think I will be able to afford to pay for their education ..I feel that I will not be able to get them very far because the fees that are charged in high school are very high" are indicative of the dilemmas and difficulties that mothers are 
facing in their struggle to give their daughters educational opportunities (Meli and Ndunge, Interviews, July 1994).

\section{Sale of Property and Farm Produce}

Women from Kilome sell farm produce for income. The women have more control over food products than livestock. Muthiani (1973) points out that among the Akamba, the participants' ethnic group, family property belonged to the family under the direct responsibility of the male head or guardian. With land policies, men were registered as the owners. Women cannot sell land or livestock without the husbands' permission, as Nzula observes in the following excerpt.

Nz: I have no authority to sell land. You see men are the ones who sell land. I can't even sell land. What can I do?

MN: Why can't you sell land and you are there and that is your home?

$\mathrm{Nz}$ : I can't because he has come and "roared like a lion" and said that this is his home and the rule is that as a woman I cannot disobey, how can I? (Interview, July 1994).

Akamba traditions and land policy introduced by colonial administration in the 1950s and reinforced after independence deny women the right to own property and specifically land. Women can only have access to land through male relatives, husbands and sons. Women who are single heads of households and married without sons have no independent access to land. Many women find it difficult to become sole owners of property because to own property one needs credit and women have limited access to credit since they don't have collateral (Republic of Kenya: Women' s Bureau/SIDA project, 1993). Without land, it becomes difficult for women to keep livestock or plant enough food for subsistence as well as for market. It is, however, important to point out 
that only about $17 \%$ of Kenya's land is suitable for agriculture, which provides the primary livelihood for about $80 \%$ of the population (UNICEF/GOF. Children and Women in Kenya: A situation analysis, 1992)

Those women who have access to land, particularly those with relatively large plots of productive land, plant food crops for their families as well as for sale. Ngina from Kyandue village has a relatively large piece of land and, recently, a small stream emerged in her plot. Ngina has utilized this piece of land to the maximum. She plants a lot of maize and beans, the staple diet of Akamba people, and uses the water from the stream to plant vegetables, onions and tomatoes for sale.

Ngina works very hard on her plot planting food crops and vegetables to sell to meet the needs of her eight children, two of whom are in secondary school and two others in training colleges. She points out that her way of earning an income is very strenuousit is a "sacrifice" that she has had to make in order to provide her children the educational opportunities that were denied her. Ngina had the following to say:

MN: How do you get money to pay school fees for your children, cloth them etc? $\mathrm{Ng}$ : Sometimes I might have sold onions and gotten my own 5,000/= (nitee kitunguu nakwata ngili syakwa itano). In fact, last season I earned 9,000/= from onions. Sometimes I find that the father to my children [who works in Nairobi] cannot afford to pay all the school fees for the children. There are times when one of the children has no school shoes, I just go and buy these things without his knowledge. I also pay the children's school fees, particularly those in the primary school and the one in the harambee secondary school. He comes and finds that his children have shoes and I have paid school fees and does not know where I got that money from. And he knows that I don't engage in any "strange business" (ndiendaa soko ili) (Prostitution).

MN: What has made your plot more productive because I know that there are many women who cannot afford to do the things that you are doing?

Ng: I have just had to "deny myself" (kwiiilea vyu) or self-sacrifice. I don't mind getting extremely tired. I work very hard every day. I leave my house in the morning and go back to the house at 6 p.m. because if I don't do that my children will suffer. You have to accept to work hard and very hard indeed and when the 
rains fall you have to agree and accept that you will be in your plot/shamba whether there is rain or no rain. You must be working on your plot because there is something that can be planted in the dry season like bananas, you can dig the holes and plant the bananas in the dry season and you know in the dry season (thano) many women stay home waiting for the rains whenever it will come so that they will wake up with the hoe going to plant. In the dry season I am in the shamba planting bananas. Before each rain season I plant about 100 banana plants and every year I plant 200 plants, every year, and you know all these bananas don't get ready at the same time because those you planted this season get ready earlier than those you will plant next season and therefore I will be getting money from the bananas through out. If I plant the bananas during the long rains (isika) I start selling them in August. And those that I planted during the short rains (thwa) which start in October) I get money from the bananas in April. It takes about a year for banana plants to mature and have bananas ready for ripening. So I sell bananas, maize, beans, tomatoes, kale and onions.

$\mathrm{MN}$ : Do you use rain water to plant the tomatoes?

Ng: No. I plant with the little water that I get from the stream. I have dug a little well somewhere where we found some springs and when that water dries up, I fetch water from the river (with a 50 litre container) to water with it so that I can give the crops enough water so that they can give me money fast..

MN: Do you think you will be able to educate your children as much as you would like?

$\mathrm{Ng}$ : As for my children, I will try to give them as much education as is possible. If only I could get something to help me get more water, if I had enough water, I would be in a better position to give my children the educational opportunities that they need. If it wasn't for that water, I would be in a lot of problems because the vegetables that I am planting right now I will sell them in the month of September and at that time we will be selling 2 kale leaves for $2 /=$ because it will be very dry. As for tomatoes we will be selling 5 for 10/=, a tin is 300/= and I will get a lot of money at that time because it is dry and there is normally nothing green in the plots. That is my catch (nukaa utekela vu, ndukwona kana ku nikutekea, nukaa utekea thano) such that in the dry season, people won't have problems with vegetable, I have some for my children and for selling.. my children eat them too. MN: Do you have a lot of people buying your vegetables?

Ng: A lot because in a day I might sell to about 20 people because sometimes I stay there at the plot until I am tired and then what I do is to harvest the vegetables and bring them home so that instead of running to and from the plot all the time when somebody comes, I have them close by and tomatoes I bring them home so that I can sell them from here because in this village, there are very few people with water.. water is a problem (Interview, July 1995).

Other women such as Mwelu, Mulee, Janet, Wanza, Maria and Manduu also plant vegetables (kale, cabbages, French beans), tomatoes and onions to sell. Rarely do women 
harvest enough maize and beans for home consumption and for sale. The women's income from sale of farm produce is limited by the unavailability of arable land, fertilizers and water shortages. Few women are as privileged with land and water as Ngina from Kyandue village. The river that used to run across many plots in Kithumba village has lost much of its water because of over irrigation and poor farming practices. None of the women living in Salama sell farm produce from their plots because most of the women do not have access to land in Salama, and Salama has no river and receives very little rainfall. Ngina's story supports Agarwal's thesis that "rural women can best improve their lives and those of their children if they own and control arable land" (quoted in World Watch, Globe \& Mail, March 1995).

\section{Petty Business}

All women from Salama town have become petty traders on a full-time basis while some from Kithumba and Kyandue villages have become petty traders on a part-time basis in order to support their families. Women from the villages take their merchandise to various market places during designated market days. Trading for the village women is not full-time because they are also responsible for all the household chores. They are ones who till the land, plant food and cash crops, cultivate, harvest, take care of the sick, work in school and undertake many other domestic chores. They must be at home daily to make sure that the livestock and poultry come home safely in the evening. Women with young children find it harder to be petty traders. Others are forbidden by their husbands. Rose, for example, is not allowed by her husband to take any farm produce to the market. He believes that business women are promiscuous (Interview, July 1994). 
The commodities that the women sell include tomatoes, potatoes, cabbages, and bananas. Others sell bar soap and paraffin. Income from these activities is not adequate to meet the educational needs of the children. Kamene, for instance, points out that her children are constantly being sent home to collect fee balances. Beth, too, notes that her daughters have had to leave school because she could not afford to pay their school fees as the entire family depended on the income from her tomato business.

Be: My daughter who finished her primary level of education is working in the shop where I sell my vegetables in the verandah. That one is a shopkeeper although she had passed and we couldn't afford to pay her school fees. All the others from the forth born to the last one are in school. The last one is in nursery school. And now we are all looking at the tomatoes (tusyaitye ala manyaanya) together with their father and my mind tells me that in all honesty my children will not go beyond Standard 8. My daughter who had two years of secondary education is even very lucky. None of the younger ones will be able to go beyond the primary level. Do you know that it is the money problem that is eliminating each one of them out of school? Now if that happens to each one of them, the result is that they don't even have a place of their own. If you have children and all those problems.. it becomes very hard. Do you hear what I am telling you? (Interview, July 1994).

The women's businesses are not doing well because the women do not have capital and access to credit. Mulee points out that she trades with only 2000 Kenya shillings and the profits are used to pay school fees by installments. Her two daughters have not been able to collect their secondary level school certificates because they have a fees balance of 9,200 Kenya shillings. Mulee does not know when she will be able to pay off this debt (Interview, July 1994).

These excerpts show that women are trying to increase the family's income by all legitimate means. Some women have become petty traders to earn money so that they can meet their families' basic and educational needs. However, the women's income is not 
adequate to educate their children and particularly daughters at the secondary level of education. The women cannot afford their daughters' education that offers them choices similar to those offered sons. The women, however, strongly believe in the usefulness of educating their daughters and they are doing the best they can to offer them meaningful educational opportunities.

\section{Limitations on Women's Efforts to Educate their Daughters}

Women from Kilome want to educate their daughters beyond the primary level. They are aware that primary education no longer guarantees the credentials for paid employment or skills for participation in income-generating activities. After all, most of these women received primary level education and they have experienced untold hardships. However, as Mwelu points out, the women's limited income opportunities are insufficient to pay the high fees charged at the secondary level. The following interview excerpt illustrates Mwelu's struggles to educate children.

MN: Let's say you had gotten the education you wanted, do you think you would have been able to educate all your children the way you would like?

Mw: I would have educated them. In fact I feel very bad (niniiw'aa thina). My mind shows me that if only I had gotten an education, I would educate all of my children to the level of their choice.

MN: What would an education have given you?

Mw: It would have gotten for me a reliable means of support because if I had read, it would be a must for me to look for something (job) to enable me to earn a living to educate my children. I do not have an income and have very little education, and the only person (husband) who has a regular earning it is very little and also he seems to lack the desire to want to educate the children. It is as though he says to himself that 'I never got an education, you are still mine that's O.K.' When it gets to that point, it gets bad (nivathuka). But if you can work hard and know the importance of education and what it will do for you even if you do not have resources, you can get somewhere. The problem is that I struggle so hard to get the children to Standard 7 by myself, school uniform, soap and every thing it is up to me to provide. I get so strained of money such that I cannot afford their fees particularly at the secondary level (Interview, July 1994). 
Many women face the dilemma that Mwelu faces. They work so hard to educate their children up to the primary level but are unable to pay fees in the secondary level of education. Some women such as Wayua and Mulee have been able to educate their daughters' at the secondary level. However, Mulee's daughters have a substantial fees balance that must be cleared before they can be given their transcripts for the university entry examinations. Most parents chose to take their children to the local day schools even though these schools lack the necessary facilities. Mulee's daughter who was called to a government maintained school in another district ended up in a private/harambee school and she did poorly in her examinations. Mwikali also observed that "we are forced to take our children to the local schools because that is what we can afford and also we can make arrangements with the headmaster to pay the fees in installments" (Kithumba Group discussion, July 1994).

The women's efforts are undermined by the cultural, social, economic and political conditions in Kenya. The implementation of the structural adjustment policies has served to entrench poverty which is central to the experiences of women. Townsend (1993) argues that the government of Kenya has failed to alleviate the suffering of the poor because of the ambiguity of both the definition and measurement of poverty. The government has continued to stress distributions of income rather than reducing inequality between the rich and poor through the redistribution of income and wealth (p. 174).

Even though the women want to give their children and daughters in particular educational opportunities denied them, the demands on women are overwhelming. Their attempts to cope with the physical and monetary demands of their labour may also 
influence negatively (a) women's health, (b) girls' education, and (c) family welfare of women's dependents.

\section{Women's Health}

The increasing intensification of women's work has had a profound impact on their health. Some women who participated in this study are physically ill due to carrying heavy loads to and from far away market places. Mwelu is suffering from severe lower back and leg pains. She cannot carry heavy loads on her back and has excruciating pains when she bends. This is very hard on Mwelu because most of the women's work in the rural areas involves long hours of bending while planting, weeding, and watering vegetables. In addition, Akamba women carry heavy loads such as water, firewood, maize and beans on their backs. Worse still is the fact that Mwelu cannot afford to see a doctor. The following interview excerpt can give us a glimpse of how Mwelu's income-generating activities have combined with her domestic roles to contribute to her present condition.

MN: What have you been doing to support your family?

Mw: I have been selling food stuffs. I have been buying green vegetables, loquats and bananas. If I cut a green banana bunch and keep it to ripen, I would go to Mavivye (about 20 kilometres away) market, where I used to take the bananas, green vegetables and other fruits. I would sell all those things and buy food in the market because food is cheaper in that market than in other markets and I would go home carrying a lot of food to last us at least a week. I used to come back and work on my plot (shamba) the whole of that week since I would have enough food for that week. If there was a "naked" child, and those days clothes were cheap, I would also buy them clothes in the same market and I would come home and work for a week on my shamba until Monday, the market day. I would go back on Monday to go and sell.

MN: Is that market better than the Nunguni one?

Mw: Yes. I liked the Mavivye market because food was cheap. At that time a kilo of maize was a shilling. Before then we used to buy a kilo of maize for a ten cents. You see if I sell those few things, I cannot afford to buy food at Nunguni but if I go to Mavivye, I could buy more food there, enough for a week. That is what I have been doing. 
MN: What are you doing now?

Mw: I just work on my shamba because my back and legs have been paining for quite sometime now. I cannot carry anything. Walking is a big problem for me. I cannot walk for a long distance on foot and I cannot bend to work in the shamba anymore.

MN: You used to carry heavy loads?

Mw: Yes, and maybe the pains are related to that. I don't know but I think it could be because I used to go carrying things and I would come back home carrying things. I used to carry a lot of things and the place is very far. The things I used to carry were way over my carrying capacity. Before this I used to work in my plot/shamba and plant vegetables which I would sell. I do not go to the shamba any more, I can't really do much because of the pains.

MN: How do you make some money now that you don't go to the market anymore?

Mw: I have concentrated on participating in these women's self-help groups. We contribute $30 /=$ or $20 /=$ and so when it is my turn, if one of my children is naked (without clothes), I buy them clothes and whatever else they need, if I can afford it (Interview, July 1994).

Mwelu points out that she cannot afford to pay a private practitioner. Ideally, she is supposed to be referred from the District hospital to the Kenyatta national hospital where she can see a specialist at government-subsidized consultation rates. Unfortunately, the government has reduced funding on health services, resulting in very poor working conditions for the doctors, most of whom have subsequently left public hospitals and joined private practice. Mwelu cannot afford to pay for private practice service.

Mw: My whole body aches but the pain started on my leg at the knee and it went up to my lower back. In the beginning I went to see Dr. Kioko who treated me when he was practicing at Salama (a nearby town) but he has since moved to Nairobi (120 kilometres away).

MN: Why haven't you gone to see him again?

Mw: I really cannot afford to go and see him. He is very expensive and he is in Nairobi (Interview, July 1994).

Ngina, from Kyandue, who talked of having "sacrificed" herself for her children's sake, mentioned that she too suffers from lower back pains (Interview, July 1994). 
Women in the rural areas are forced to neglect their health as they get engrossed in meeting their families' material and emotional needs. Women will ignore symptoms of sickness because they cannot afford to take time off to see a doctor and because their health is not a priority in the competition for the limited income they earn. Even in times of food shortages, women tend to eat less. Women's poor health serves as a great blow to their dependents as they become unable to perform their roles as food producers, income earners and care givers.

\section{Girls' Education}

Women of Kilome division are certainly playing a major role in the education of their children. As Ngina points out, "participation of mothers is a crucial factor in the education of their children" (Interview, July 1994). However, as the demand for women's labour increases some women might have to relegate some of their domestic chores to their daughters. This might mean that these girls will miss school to take care of the younger siblings while the mother takes her wares to the market or she works as a casual. Some parents might also withdraw their daughters from school or fail to take them to school and send them to work as domestics to help support the family. Kamene and Wanza, two women who participated in this study, left school in Standard 3 to work as domestics to help feed their families (Interview, July, 1994). Kamene now struggles to educate her four children with the money she gets from her tomato business. She has expressed deep concern at her inability to meet her children's basic needs and educational needs. Many girls have joined the growing number of child labourers. Child labour is still rampant in Kenya, with some working children as young as six years old. The little money 
children earn can never compensate for the environmental hazards they face or the lifelong impact on their growth, especially their psychological, emotional and educational development (UNICEF/GOF: Children and Women in Kenya: A situation Analysis, 1992).

Beth's daughters too have had to leave school to work as domestics because Beth could not afford to pay school fees for them or take them to a college to acquire employable and/or income-generating skills. Most domestic workers, particularly children, are the most easily exploited of all workers. There are no set salaries for domestics. The salaries to be paid depends on the whims of the employer. Child labourers are likely to be sexually exploited by their employers and others. These encounters lead to teenage pregnancies.

\section{Impact on the Welfare of the Family}

When a woman is ill, the whole family suffers because of the multiplicity of roles that a woman performs. The repercussions are phenomenal. In the Ndegwa Report (1991) it is argued that "the quality of a country's labour force is to a large extent dependent on women's performance as mothers, the custodians of family health and welfare, especially that of young children, aged and sick" (p.229). The illness of a mother limits educational opportunities of her female children who are called upon to take up their mother's roles as food producer, childrearer and caregiver. Female children have also become child labourers so that they can earn money to support their siblings.

Because of the multiplicity of women's roles in the family, particularly as food producer, prolonged illness will subject the family to food insecurity. Women, however, 
have organized themselves in women's self-help groups to support each other in the changing social, economic and political context of Kenya society.

\section{Conclusions}

The women's discourse on education shows women's awareness of the importance of the education of women and their agency in providing educational opportunities to their daughters. The women aspire to give their daughters education that allows them to participate in the public sphere as do their male counterparts. Kilome women know that women are not just "helpers" of men but are active participants in shaping the lives of their children. They want their daughters to be self-reliant and have economic independence. The women want their daughters to make choices and own and control property like their male counterparts. They are aware of the barriers that women face in their efforts to attain educational opportunities. Consequently, they have become their daughters' intervention agents.

The women are engaged in a multiplicity of labour-intensive activities in order to earn an income in a gendered economy. Their income-generating activities are limited and their efforts to provide their children with educational opportunities are impeded by the high school fees that are charged, particularly at the secondary level. The introduction of the cost sharing strategy has had negative impact on the education of girls. In addition, the intensification of women's labour is detrimental to their health and has negative impact on the education of girls. However, in the midst of these harsh conditions, women have reached out to traditional principles of organizing and are working as a collective in 
the form of self-help groups to afford their children educational opportunities. These women's self-help groups are discussed in the next chapter. 


\section{Chapter 8}

\section{"Help Me So That I May Help You": Women's Self-Help Movement}

The women's discourse on education shows that their educational and economic opportunities are limited by cultural, social and economic factors. It also shows women's agency in their effort to offer their children, and daughters in particular, educational opportunities. Mothers have been working very hard to give their daughters educational opportunities because they know the importance of women's education. The women pointed out that they left school against their wishes. They lacked intervention agents to support them in their struggle to obtain educational skills. The women are doing whatever is possible to give their children educational opportunities.

It is evident that these women have become intervention agents for their children's and particularly girls' education. They realize that without education, their children, and daughters in particular, will not be able to support their own families and themselves. They want their daughters to be self-reliant and to break out of the poverty into which they were born. The women's efforts are not recognized and they are not receiving support to intervene in their children's education in more effective and in meaningful ways. The government does not seem to be aware of, or does not recognize, the increasing burden that women and parents are bearing to educate their children. The implementation of the structural adjustment programmes are hurting the poor, and these happen to be women and their dependents. These programmes have a negative impact on the health of the women and on the education of girls in particular. Even though the 
women have "sacrificed" themselves to offer their children educational opportunities denied them, the demands on the women are overwhelming. The women's efforts are hampered by cultural, economic, environmental and political factors.

However, as Dei (1995) observed, "village women have been known to rely on long established traditions of community solidarity, based on traditional principles of group mutuality to help to relieve the economic pain of households" (p. 12). In Kenya, women's self-help groups have flourished as a means for women to cope creatively with the sweeping postindependence economic and social change and with the exigencies of a neocolonial political economy. ... The practice of cooperation and the discourse of communality surviving from precolonial times animates the women's contemporary self-help groups. (Stamp, 1995, p. 73)

Women's self-help groups in the traditional setting became necessary as a collective geared at identifying a task and putting their resources together to work on the task. "The concept of groups was based on mutual social responsibility, accountability and reciprocity" (Republic of Kenya: Women's Bureau, 1992). Women's self-help groups in Ukambani are similar to the traditional work parties or myethya (Hill, 1991).

The majority of present day women's groups are self-help groups. The original objectives and aims have changed to accommodate the rapid political and socio-economic changes. Women's groups are seen as a force to improve the position of rural women in Kenya since they contribute substantially to raising standards of living and to bringing infrastructure to rural areas. In 1992, there are about 23,614 women's groups in Kenya (UNICEF/GOF, 1992).

As noted earlier, the government requires that women's self-help groups be registered with the Women's Bureau, Ministry of Social Services. The registration 
enhances government control over the political activities of these groups. Women's groups are not supposed to engage in politics particularly aligning themselves with opposition parties.

Many groups have registered themselves with the Women's Bureau to legalize their group meetings since the government has made it illegal to hold a gathering without a permit from the divisional president's office. Women's self-help groups that are registered with the Women's Bureau also stand a better chance of getting aid from International Development Agencies channeled through the Women's Bureau. The Women's Bureau was set up in 1975 to co-ordinate government policies towards women through the "Women's Group Programme." Feldman (1983) points out that the Women's Bureau serves to legitimate certain kinds of "special treatment" for women on the grounds that women have been disadvantaged in the past. These special programmes for women are initiated, controlled or coordinated by government agencies, while women's self-help groups' activities are initiated and controlled by the women

During the research period, I worked with three women's self-help groups, namely Kithumba, Kyandue and Salama women's self-help groups in Kilome division. These groups were set up by the women from these villages to address their own identified concerns. Kyandue women's self-help group is the oldest among the three groups. Kithumba and Salama women's groups were formed during the research process by the women who participated in this study. 


\section{Kyandue Women's Self-Help Group}

Kyandue village has one major women's self-help group which is, as noted earlier, divided into sections A and B (Rachel and Meli, Interview, July 1994). The groups operate as a single group or as two entities depending on the nature of the tasks. The group functions as a single group when they engage in community work such as in the building of gabions. One section of this group is composed of women married to men belonging to the Ambua clan. As noted earlier, this group was formed out of a tragedy and its primary role is to formalize those marriages in the Ambua clan that had not been formalized and to ensure that future marriages carried out in this clan are formalized.

In the traditional setting, the process of "sealing" or formalizing the marriage relationship was long. It began when a young man and his family were accepted as suitable suitors by the bride's father, the bride and her mother. Two goats (male and female) were sent to the in-laws-to be. Along with them went a leather strap (Muthiani, 1973, p. 26). Other gitts followed but the most important ones were the two goats. This was done by the young man's parents and relatives. In Kyandue, the women are taking charge of the situation and ensuring that the marriage relationships are sealed not only to prevent burial disputes but also to ensure that their children's lineage is not threatened. Rachel had the following to say about her group.

MN: You told me that you sell firewood to earn some income and you also mentioned that you are the secretary to one of the self-help group. What does your group do?

$\mathrm{Ra}$ : As you may remember, I told you that we try to formalize marriages as they should have been done traditionally by pay bridewealth (kuasan'ya ${ }^{1}$ ). People have stopped paying bridewealth as they used to and this is bringing a lot of problems today.

MN: Why would you want to pay bridewealth for each other?

\footnotetext{
'Kuasan'ya is not the equivalent of "paying" bridewealth. The Kamba word for "paying" is "kuiva" or "kuthooa" which is different from kuasan'ya.
} 
Ra: What made us to insist on formalizing marriages is because one woman married in our clan died and there was a big problem because her husband had not even taken the two goats to her parents. So, her people wanted to bury her and our man also wanted to bury her and here were the children caught in between. It was very sad and so anyway, our clan had to contribute money and items to take to the deceased woman's parents so that we could bury her. When we looked around, we realized that our deceased co-wife was not the only one whose marriage had not been formalized. In fact, I was the first one to have my marriage formalized by this women's self-help group. I was married in 1977 and the two goats that are taken to the bride's parents were taken there in 1989.. how many years are those?

MN: Over ten years.

Ra: They (the group) said that they were not going to stay with somebody's daughter without having gone to see her parents. It is also a sign of respect to the woman's parents. Anyway, I was the first one to benefit from that process. The members of the group bought six goats, maize, beans and other items to take to my parents (kumova mukwa).

MN: Did your husband participate?

Ra: Yes, what could he do?

MN: Do the other men and the spouses of the women in the group come along?

$\mathrm{Ra}$ : Yes, they come along. The whole process is taken very seriously (interview, July 1994).

The group engages in many other activities besides formalizing marriages. Meli is the overall chairperson of the Kyandue group. She notes that the group's activities are also geared towards increasing food security and providing support for women and their children, as well as increasing women's income. The group members plants bananas for each other.

Me: I am the [chairman] sic of the group. Since we got together we decided to plant bananas so that when it gets dry and there is a food shortage (famine) we can cook for our children these bananas. When the rains fail women experience a lot of difficulties trying to feed their children. You have to have money to buy food and sometimes you can have the money and then you find that there is no food in the shops. I am sure you can remember the previous famine which people branded 'I'm dying with money in my pocket' (nikw'a ngwete). Also, you know how bananas are in demand these days? So women can also sell these bananas when they get ready (Interview, July 1994). 
Rachel, who is an official of Kyandue women's self-help group, points out that its motto is "Help me so that I may help you," and this has worked very well. She has benefited from the bananas that she was helped by this group to plant (Interview, July 1994).

At the time of this meeting Kyandue women's groups had 3,000 Kenya shillings $(\$ 100)$ in their saving account. They felt that their group did not have a large saving because members are needy/poor and also the group did not have a sponsor to assist it get funds to boost its projects from the Women's Bureau or any aid organization. Meli notes that:

Me: So far we have only 3000 Kenya shillings in our account and we will start buying maize which is being sold cheaply now because people are harvesting. We will keep this maize until the dry season when the prices will go up and then we will sell it and all the profit will go to our account. Our group weak, it is not wealthy (nikyonzu) because we have not found a way to get the money that many women's self help groups are getting. Right now we make our money by hiring out our services. We carry bricks for people, we till the land, we carry firewood. We also pay 20 Kenya shillings each member monthly. We are paid about 300 Kenya shillings to carry 3,000 bricks.

MN: How do people get to know about your services?

Me: By word of mouth.. that is how we get hired (Interview, July 1994).

Meli's self-help group has not attracted aid from the various government or nongovernmental agencies as some groups have. As Udvardy (1988) observes, the process of nominating a women's self-help group for a grant from the Women's Bureau is long and I would say, corrupt. Often there are more groups nominated than there are funds available.

The Kyandue women's group creates possibilities and offers options to its members. For example, they were able to save a widow her piece of land which she was about to sell in order to get money to bury her husband. The group advised her against 
selling the land, gave her a soft loan and worked out with her a better way of repaying the loan without losing her land. Meli observed that:

Me: We contribute 20 Kenya shillings every month for our joint account and we are 48 members. We have used the money to get a certificate (170 Kenya shillings) from the Ministry of Social Services. We use the rest of the money to support our members in different ways. For example, one woman who lost her husband and wanted to sell a piece of land, we gave her the 2000 Kenya shillings she needed so that she wouldn't sell the land (soil). We helped her and that is why our account went down. We saw that land is hard to come by and therefore we discussed with her about better measures to undertake other than that one of selling land.

MN: How will you get this money back?

Me: She told us that she will sell a cow that she has and give back something to the group because even with one 1000 Kenya shillings one can buy a calf. This is in line with our goals because when we started the group, the goal and purpose was to support each other so that our women do not have to sell valuable things like land when faced with emergencies such as death in the family. We also help to pay school fees. Recently we contributed 1000 Kenya shillings for a member to take her child back to school after the child had been sent home to collect school fees balance (Interview, July 1994).

The availability of bananas in Kyandue is a new phenomenon. The women told me that prior to the introduction of the self-help group, many women did not own a single banana plant. During my fieldwork, I learnt from the women that the production of bananas in this village had already attracted banana buyers from other divisions and locations outside Kilome division. This has not only increased food security in this area but also increased the women's income.

The women's group's ability to adapt and respond to the changing social, economic, environmental and political changes is a great asset. Meli feels that women can play a central role in the education of their daughters by expanding the vision of the women's self-help group. 
MN: What do you think women should do to educate their children?

Me: I think that women must come together (tukwatane muva $i^{2}$ wa aka), unite and make contributions for each other (kusangulanila) and educate their children because if we rely on men our children will not succeed in education. We can also unite to plant crops that might help us. Like in our group we plant bananas and cabbages and these have helped us a lot (Interview, July 1994).

Manduu, too feels that women should make girls' education every woman's business. She had the following to say.

I think the only thing we can do is for us mothers to unite (twithiwe na ngwatanio) so that if our daughters pass, we ensure that that the girl does not sit at home because of school fees. The child's education should not just be the individual family's responsibility (mwana usu ndethinya nyinya na ithe eweka) so that we can begin to educate our daughters. We mothers should be in a position to do so. This unity I'm talking about is like a women's self-help group because men don't like that kind of unity (Interview, July 1994).

\section{Kithumba Women's Self-Help Group}

The need to form Kithumba women's self-help group came from the women's realization that they could achieve more if they worked as a group. The impetus also came from Kithumba women realizing what Kyandue women's self-help group was doing and aimed at doing. Kithumba women identified poverty as the single major "ailment" common to almost all women in this village. A women's group was seen as necessary to improve women's economic and political status. This would enable the group to offer their children, and female children in particular, educational opportunities. Catherine observed the following:

What I think we need to do is start a women's self-help group so that we can begin to talk about the problems that we face as a group. So, if it is the education of our daughters, we as mothers should all feel responsible and plan on how to deal with the problem. Women are very innovative and I think we can collaborate to address our girls' educational needs. We need to challenge each other and be each others' eyes (Interview, July 1994).

${ }^{2}$ Muvai means a specific group with special characteristics 
The group plans to provide credit to its members, some of who are petty traders who cannot be given credit by financial institutions because rural women do not have collateral. The women have started buying bar soap at wholesale prices and selling it at retail prices but one shilling cheaper than in the shops to attract customers. The profit is kept in the women's self-help groups saving account. There is no maize mill in the area and the women are aiming at purchasing one which would bring them more income, give them more options and give them more resources to support their children, and daughters in particular, to acquire meaningful education (Ndoti, Interview, August 1994). The group would like to plant green vegetables if they could get help to drill a borehole $\mathbf{3}^{3}$ which would have enough water to enable them to plant kale (sukumawiki), French beans for export and tomatoes and cabbages for the local market and their own consumption (Mulee, Interview August 1994). The aim is for the women in the group to support each other to become self-reliant. The women want to be able to take control of their children's needs as illustrated by the following interview excerpt with Mulee when I asked her about government bursaries.

Mu: I understand that the government helps. I don't know how because for all my children I have sent a report to the government office here at Kilome. I have taken the report to the Assistant Chief to try to get a bursary for my daughter and I went to all those offices they asked me to go to but I never got anything. I really don't know how the forms and funds disappear (ndyisi syiisa kwaia va). I don't ever get any clear information on what happens to them and so I have given up with that avenue and said that let it go whichever way it will go (ithi oundu yai nethi). Otherwise I don't really follow up on what the government really does.

What I always pray for is to get money, money that I can work or sweat for, if I could get about 50,000 Kenya shillings as capital I could do a lot of things such that by the end of the month I could earn about 3,000 shillings, you know that would be like a salary just equivalent to that I would have gotten if I had gone to school and become a primary school teacher? Knowing very well that what you

\footnotetext{
${ }^{3} \mathrm{~A}$ borehole is a deep well that is drilled using machines.
} 
are doing you will get about three thousand shillings. That would be a salary and to get that you need to have about 50,000 Kenya shillings. and you know what to do. I want to be able to plan for my children knowing that I am able to support them myself and not relying on handouts. What women need is to be supported to support themselves and their children on a daily basis. That is what we should aim for, to be self-reliant (Interview, July 1994).

The women also expressed the need to use their group meetings to discuss issues that affect them. These include violence against women and women's health. We discussed AIDS/HIV which the women felt was extremely important to discuss as it affects women, and most women do not have radios to listen to for current information. More importantly, the women, as members of a self-help group had become comfortable with each other to ask questions and to share information. The women noted that there is a big gap between themselves, policy makers and those who claim to speak on their behalf. They observed that elite women who claim to speak for women do not have a clue of how women's life is at the grassroots level. "We have never seen any of them come to the village to talk with us here. They know where women can be found, we are in the villages!" (Manduu, Interview, July 1994)

The women discussed how they are treated by doctors when they go to hospitals. They noted that most doctors don't seem to respect them at all as women and mothers. They lamented that many doctors do not treat women with dignity and tend to treat them as though they are "dirty." The women would like to go to hospitals with themselves new needles to ensure their safety (Kithumba Women group, August 12, 1994). Collaboration between the women and increased income was seen as the only possibility of achieving these goals. 


\section{Salama Women's Self- Help Group}

Prior to the inception of the research project, Salama did not have a women's group.

As Beth points out, people in Salama, as in other urban settings, lead "atomistic" lives.

MN: Do you ever talk or discuss your experiences and concerns with other women in the town? Do you have women's self-help group or a forum within which you can air your concerns?

Be: Did I tell you that here we live as single entities? We keep our problems to ourselves. Each one of us carries their own "cross" alone.

$\mathrm{MN}$ : Why is life like that here?

Be: In this town people live by themselves as entities, everyone for themselves. The town has good people.. I will build and demolish (niaka na ndiomboa). If they had a leader to tell them to organize those who would listen and pay heed and those who wouldn't, we wouldn't talk about them because in other towns they have leaders, committees of women and men who lead in bad and good times but this one does not have such a committee. In my understanding, I feel that if it (Salama town) had such a committee there would be some rules that we could follow since we are residents here and we would be different and have some plans or you plan for yourselves. Now there is nothing like that. Everyone lives here and does whatever they like. Nobody cares about what the other does, you rely on yourself. If you sell tomatoes like I do, you go ahead with your tomato business to wherever you'll emerge (ukaumbukila kula ukaumbukila). Do you want us to tell you that we do anything as a group while we do nothing? (Interview, July 1994).

It is understandable why Salama town did not have a women's self-help group

prior to my entry into the site. The individualistic lifestyle that women and men lead in

Salama is characteristic of urban areas. Nevertheless, ten women of Salama, together with three men, noted the importance of a group in addressing issues confronting them. Among their pressing needs was girls' education. Beth points out that girls are leaving school because of poverty.

Be: Do you know that it is the money problem that is eliminating each one (her daughters) of them out of school? Now if that happens to each one of them, the result is that they don't even have a place of their own. If you have children and all those problems, it is hard. Do you see? (Interview, July 1994) 
All the members of the group are engaged in some form of business, but they point out that the business is bad because they don't have enough capital and therefore they do not have enough money to meet the needs of their children's educational needs.

Do you know that each one of us, the business that we are doing, small as it is, if it had stock, we wouldn't be lamenting or struggling the way we are doing right now. Shortage of money is what is making us cry for help (kukaya). Everyone of us here is saying that their child got to this grade and did not move on because of school fees. If the business that we are doing was more profitable, we would take part of that and take it to school to pay school fees but we are unable to meet these needs. Again we don't know how to support each other (Kamene, Interview, July 1994).

The women pointed out that it is important for people not to forget their traditional principles of collaboration. They pointed out that, traditionally, people worked together for the betterment of the community. There was an emphasis on collaboration as exemplified in saying such as "one finger cannot kill a louse." The women felt that the formation of women's self-help in Salama was long overdue.

When the group was formed, each member was asked to pay a membership fee of Ksh 140 (CDN 4.50) within a period of one week. The women decided to build a kiosk for selling boiled eggs and cold drinks in front of the market. The kiosk bore the name of the group-Salama Women Development Group. This small progress attracted many women to the group. Membership in the group was dependent upon the consensus of all group members.

The Salama women's self-help group has big goals. The group intends to buy a maize mill which would bring them a better income if well managed. Salama has only one maize mill and this forces women to wait in long cues for hours to have their maize milled. The women feel that a maize mill would improve their individual living conditions and enable them to offer their children better educational and economic opportunities in Kenya. 


\section{Successes and Limitations}

A large number of women's self-help groups that are started disband within a short period of time. Kyandue women's self-help group has been in operation for about two years and its achievements are concrete. For Kithumba and Salama women's groups the momentum is high. Kithumba women had completed the handicrafts they were making during the first two months of the group's inception. The women made traditional Kenyan baskets, sisal ropes and table clothes. The ropes were bought by members for carrying loads and tethering livestock. A certain percentage of the sales was saved in the women's saving account.

The Salama women's self-help group was diversifying its business very rapidly. The group sought registration with the Women's Bureau and they have already opened a saving account with Kenya Commercial Bank. The latest report that I received from these women at the end of March 1995 is that the group has hired a woman to sell in their kiosk and they have saved over 7000 Kenya shillings ( $\$ 300)$.

One major limitation faced by the women's groups is patronage by men. The patron-client relationship can be formed between the women's self-help groups and certain males, affecting the independence and success of the women's groups. Udvardy (1988) notes incidents in Kilifi where men involved themselves with women's self-help groups because of the greater access women's self-help groups have to development aid. Furthermore, the women not only constitute a necessary component but also a convenient labour force (p.223). 
Women's self-help groups' autonomy is limited by politicians who want to control the groups for their political ends. For instance, Kithumba and Salama women's groups were experiencing pressure from the local ruling party representative who vowed to alienate the groups' activities if they were found to be supporters of opposition parties. The representative claimed that these two groups were formed to solicit votes for an opposition candidate in the 1997 general elections.

Politicians' interference with women's self-help groups limits women's autonomy and also limits the people the group can call upon to support them in their projects or for a funds drive. Many women's groups do not want to be declared "controversial" or to have political affiliations with opposition groups because that limits aid to these groups from the government or from international aid organizations who fear being accused of interfering in a country's internal affairs.

The activities of these women's self-help groups in Kilome division are limited by the capital they can raise through their income-generating activities and their monthly contributions. As the women observed, they have not been able to attract any grants from the government or aid organizations. The women need funds to purchase a mill to increase their income to meet the educational needs of their children. They also would like support to drill a borehole in order to get water for irrigation. All these activities need credit to which the women have no access. The women are not aware of how they can access aid money that has been made available to other women's self-help groups to fund similar projects. In addition, they do not have information on accessing credit from 
financial institutions. Nevertheless, it is difficult for these women to get loans from financial institutions without collateral which they do not have.

The women's self-help groups' potential for addressing issues of concern to themselves and their children is impeded by internal and external factors. The paradox is that the women's self-help groups are supposed to be apolitical and yet to have political affiliations with the ruling party! However, women's self-help groups need autonomy in their efforts to meet the educational needs of their children. Any support given to them by government or by non-governmental organizations should be "unattached." The support should not be for "development" projects as conceptualized by the government or development organizations. As Dei (1995) argues, "development should speak to the social, economic, political, spiritual and cosmological aspects of local peoples' lives, as well as their specific needs and aspirations. It should reflect the lived realities, goals and aspirations of grassroots people" [women] (p. 16).

\section{Exclusiveness of Women's Self-Help Groups}

As a participant in the women's group I learnt that, although membership in women's groups is open to all women, the conditions of membership excludes a large number of women. For example, some women are not able to keep up with the weekly/biweekly or monthly contributions that are expected of members. Rose has limited her participation in women's self-help groups because of this factor. In fact she dropped out of Kithumba women's group as she could not afford to make the weekly contributions. 
MN: Are you a member of any women's group?

Ro: I belong to one group called Maka Weka (worry alone). I try not to join many groups because it is expensive to do so and my income is almost nothing. The group I participate in we fill the canyon/ravine with stones and we are given food once in a while. The group is associated with the Catholic church. We also have had to pay 80 Kenya shillings to pay a watchman to look after the maize.

MN: How do you get money?

Ro: I only get money if I have a banana bunch that I ripen and sell it. This happens once in a very long time (Interview, August 1994).

Kasika from Kyandue had a similar reason for not joining Kyandue women's self-help groups. She pointed out that "one needs land and money to participate in these groups. I have very little land and no space to plant bananas and so I couldn't join this group although it is good for me to do so but I cannot afford it" (Interview, July 1994). The government's demand for women's self-help groups to be registered with the Women's Bureau increases the pressure for women's self-help groups to raise money. To register, each group must pay 170 Kenya shillings for a certificate. When there is an harambee (a fund-raising drive), women's groups have to contribute a certain amount. When I was in Kenya, each women's self-help group in Kilome division was expected to raise 1,500 Kenya shillings towards an harambee that was to be chaired by the Minister of Foreign Affairs. All this money had to come from the women. As Ngina observed, "a woman must find a way of making her own money because if she always has to beg from her husband to make these contributions, he will not tolerate that begging and soon he'll ask her to leave the groups." (Interview, July 1, 1994).

The membership fee for the Salama women's self-help group also is too high for many women to afford. The membership fee is 130 Kenya shillings The women insisted that this figure was the basic amount they needed to start a small business. However, 
Kasika, Rose and Kadongo noted that these rates are too high for them because they do not have a source of income and do not have a piece of land where they could plant vegetables for income. Present day women's self-help groups exclude the poorest women who need the group's help the most (JASPA, 1981). The women's desire not to rely on government handouts for their projects unfortunately eliminates those poor women who cannot afford to raise the membership fees.

\section{Conclusions}

In this chapter I sought to highlight the potential and limitations for women's agency as a collective in the form of women's self-help groups. Women's self-help groups are ubiquitous throughout rural Kenya and have been formed on traditional principles of mutual interdependence. As Stamp (1995) observes, these groups flourish as a means for women to cope creatively with sweeping postindependence economic and social change and with the exigencies of neocolonial political economy.

These groups have the potential to address issues concerning women's education since the groups are based on the practice of cooperation and communality. As the women observed, girls in Kilome division continue to experience gender-related difficulties in accessing educational opportunities. The women know the importance of education and aspire to give their daughters educational skills to enable them to participate in the modern economy. They realize that their efforts to educate their children are limited by lack of resources. On the other hand they see their potential as a group in supporting each other in their efforts to meet their children's needs. They recognize the importance of identifying issues that concern them and planning ways to achieve solutions. The 
women's self-help groups that I worked with have made great progress towards achieving their goals. However, these groups' activities are limited by lack of credit. The women's income-generating activities could be improved if they had capital. However, women cannot get loans from any financial institutions because they do not have collateral. The women see their unity as a collateral which they can utilize to solicit financial support in the form of loans in a similar fashion as the Grameen Bank of Bangladesh. The Grameen Bank gives loans to landless, assetless women who form a group that acts as a collateral. The group ensures that a member who takes out a loan from the bank repays it (IDEAS, 1991).

Present day women's self-help groups, however, tend to eliminate the poor women who do not have access to land and money to make the weekly contributions. These groups are also affected by political interference that limits their activities and affiliations. However, as Maina-Ahlberg (1991) observes, dominated women's self-help groups in rural Kenya are still an important resource for change. Women have continued to exploit the power of collective action to counteract negative forces within the system even after colonial forces had disrupted their culture and collective organization.

Continued collective participation of women has not just offered a link between the past and the present, it constitutes a process of consciously selecting positive cultural traits and adapting them to meet new challenges. It is perhaps only through such dynamic participation that issues which evoke resistance can become an integral part of the collective activity and social order. (Ahlberg-Maina, 1991, p. 187)

Stamp (1986) argues that women's self-help groups are not simply cooperative development projects, or strategies for coping with change, rather, they are vital organizations for resistance to exploitation. Women have become agents of resistance and 
change in the maelstrom of contemporary Kenyan affairs. For instance, some women in this study noted that they have shifted their labour to subsistence agriculture because they have more control over the food products than in cash crop productions. Their agency resides in their communal endevours and is constantly reinvented in the context of political and social changes (Stamp 1995). 


\section{CHAPTER 9}

\section{Conclusions And Implications For Policy}

In this chapter I examine the public discourse on education of women and men articulated in Kenyan policy documents in light of the women's private discourse on education constructed from the interviews with the rural women of Kilome division. I juxtapose the women's perception of themselves and the purpose of women's education with the envisioning of women held by predominantly male policy makers. The women's discourse shows a strong belief in the relationship between education and economic development. While the women identify the gender-related factors that limit their participation in education and in the economy, they do not image out systematic ways of challenging the institutionalized structures that continue their subordination. I discuss the implications of the policies on women's education. Finally, I examine the implications of this study for policy and research.

\section{Research Problem}

The public discourse regarding the purpose of the education of women and men in Kenya is set out by predominantly male politicians, and policy makers, and is influenced by international development agencies such as the World Bank. In the formulation of educational policies, gender issues are either framed in ways that confine women's agency to the private sphere and fail to challenge the gender and power factors that impedes women's agency in the public sphere alongside men. Consequently, the factors that limit 
women's participation in education and in the public sphere remain invisible. The implementation of the ensuing seemingly gender-neutral policies has negative implications for women's education and reinforces existing gender inequities in Kenya.

\section{Public And Private Discourses On Education}

An examination of the public discourse on education articulated in policy documents produced in Kenya in the last three decades since independence (1964-1993) shows that gender has been framed in ways that limit women's agency in the Kenya society. In addition, the gender and power-related barriers that impede women's participation are not addressed.

The policy framings that have limited women's access to education include (a)

gender neutrality, (b) perception of women as reproducers and men as producers, (c) educational policies produced by predominantly male policy makers, and (d) nationalist policies of equal education and economic opportunities that failed to address gender and class issues.

While some policy documents assumed a gender neutral perspective in the formulation of educational policies, others limited women's agency to the private sphere where they are "biologically responsible for bearing and rearing of children." Other policy documents recommended policies that would exclude an overwhelmingly majority of women. As Staudt and Parpart (1989) posit, women's seemingly personal, everyday experiences are structured by policies most of which are outwardly "gender-neutral" but are in fact experienced differently by men and women. Therefore, women, who have been systematically relegated to a private non-economic sphere created in the colonial era, and 
inherited, maintained and developed in the postcolonial era have had different experiences of these policies than do men. These women's agency has continued to be marginalized into the private sphere. The Kenyan state, and the economy, education and political systems it inherited and developed, are overwhelmingly controlled by men, and this control has translated into laws, policies and spending patterns which not coincidentally benefit men. Male dominance in the public and private sphere impedes women's attempts to create possibilities for their children in Kenya today.

Staudt (1987) points out that nationalist movements, by their very nature, focus on the struggle for independence, rather than on gender or class interests. The goals of the nationalist movement in Kenya were no different. At independence, the demands of the Africans for equal educational and employment opportunities were paramount. These demands were reflected in the educational policy recommendations of the first Kenya Education Commission, commonly known as the Ominde Report of 1964 . The emphasis in the Ominde report was equity for the "African race" that had been discriminated against in accessing opportunities in the colonial period. Policies were recommended by predominantly male policy makers and implemented to ensure that the image reflected in public institutions and in the formal employment sector was African. This was made possible through the implementation of the Africanization policy designed to Africanize formal institutions in Kenya. No equivalent gender equity policies were provided to address women's unequal access to educational and economic opportunities initiated by the colonial administration which provided education along both race and gender lines. 
At independence, few women got the opportunity to train for the high level skills required for economic growth and Africanization of the formal employment sector. The policy makers, predominantly men, certainly did not see women as major players in the public space of economic activity. By this time, women's role in the public space was insignificant since colonial policies had succeeded in making the public sphere the world of men by confining women to the private sphere where they increasingly became dependent on men. The image or perception of men as "producers" and women as "reproducers" and dependents of men certainly influenced the policy makers who did not offer women opportunities to acquire the high level skills needed to participate in the modern sector. Consequently, policy makers formulated policies that reinforced the legacy of women's low participation in the public sphere which has been carried over to the present day where women form only $22 \%$ of the formal employment sector. The emphasis at independence was, therefore, to address the race issue and educational policies were formulated to "revolutionarize" the public sphere from a predominantly white male image to a predominantly African male image. The assumed gender-neutral policies promoted and reinforced gender inequities in post-colonial Kenya.

Since independence, much of the public discourse on education has emphasized provision of only basic education to women. Educational reports have emphasized the role of basic education for improving women's productivity in the informal sector. The public policy discourse also has emphasized basic education for enhancing women's delivery of gender-specific services as mothers, wives and child bearers and rearers. The public discourse has continued to portray women as biologically responsible for bearing 
and rearing of children and therefore solely responsible for the reproductive labour. Policy makers have recommended that women be given basic education to help slow the population growth in Kenya. This image of women as "biologically" responsible for childbearing and rearing has made women targets of population control programmes and has relieved men of responsibility over their role in procreation and has placed the entire burden and labour on the shoulders of women whose workloads have tremendously increased. It is upon this logic that school girls who conceive while at school are sent away from school without a hope of ever re-entering the school system.

Rural women in this study emphasized the need for their daughters to acquire higher educational skills that can afford them economic independence. The women want their daughters to be able to participate in significant economic activities in the public sphere. The women desire for their daughters an education that offers possibilities for economic independence and self-reliance. The women note that marriage is no longer a solution and that a woman can no longer depend on a man to meet the needs of her family. The rural women want their daughters to be able to lead less strenuous lives than themselves. They know that basic education has restricted their participation to the private sphere where they face enormous constraints in their efforts to provide the basic needs for their children.

The women in my study emphasized the need for their daughters to get education that can lead to paid employment. They see higher education as capable of giving their daughters the opportunity to enjoy what Patricia Mann (1995) refers to as social enfranchisement of women. With social enfranchisement, the scope of women's agency 
changes as they enter the public sphere as economic and political agents alongside men. The women of Kilome want their daughters to be able to make individuated rational choices about their social, economic, and political destiny as do men. They want their daughters to be in a position to choose whether to get married or to remain single. The women are opposed to their conditions of existence which are characterised by dependence, subservience and insignificant economic roles. They want their daughters to participate in the world of those who own and control property and are active participants in the modern state (Staudt, 1987). The women are aware of how their agency to provide for their children has been limited by the sexual division of labour outside and within procreation and between procreation and production (Jaggar, 1983). These women, however, do not propose radical measures to address the structures that continue their subordination.

The women's discourse on the role of education in economic development supports the policy discourse on the role of education in development. However, the women's belief that education leads to paid employment in the modern sector is not supported by most policy documents that emphasize education for rural development or vocationalization of education for self-employment. Their strong belief in the importance of education is matched by the activities that women are engaged in as mothers to provide their children educational opportunities. They are engaged in a multiplicity of activities to earn income to meet the ever-increasing costs of education instituted by the government through the cost-sharing policies. 
The women in this study identify the factors that limited their participation in education as well as those that continue to limit girls' educational opportunities in Kilome. They note that poverty is the major factor that is denying their children, and daughters in particular, educational opportunities and thus limiting their chances of participating in the formal employment sector. The women do not question the structural factors that have enabled the creation of the impoverished conditions they live in. Rather, the women are determined to "sacrifice" themselves to do their best to afford their daughters educational and economic opportunities denied them by social, cultural, economic and political factors. The women specify the following factors as limiting girls educational opportunities: (a) high school fees, (b) gendered assumptions about girls' sexuality-potential motherhood, and, (c) pregnancy rates among high primary and secondary level girls. While the women identify the impediments to girls' educational opportunities, they do not see the possibility of challenging the structures that maintain them.

The increasing school fees being charged in secondary schools are a major barrier to girls' education. As one participant pointed out, at present the education of girls is worse off than it was a decade ago. Fewer girls are able to complete the secondary level of education. Mothers know that primary level education does not offer the resources that enables one to be self-reliant. This is true of the experience of a good number of the women who participated in this study. They received seven years of primary education but have not found any meaningful income-generating opportunities.

The barriers that women encounter in accessing educational opportunities were not highlighted by policy makers, rather, the policy makers recommended an increase of 
parents' responsibility over the education of their children through the cost-sharing strategy. The implementation of this policy has tremendously increased the demand for women's material and physical labour and has had a negative impact on girls' education. Women in this study noted that, more than ever before, more parents are having to make choices about whose education is worth investing in. In almost all the cases, the choice has been to invest in the education of boys because girls are still considered "transient."

These rural women have "sacrificed" themselves to offer their daughters educational opportunities to increase their employability. They see education as a tool that their daughters could use to (a) to make choices--whether to get married or not, (b) to own property, and (c) support their mothers and families. These women's work, however, has increased tremendously as they have picked up new roles and challenges in a gendered economy.

The women's sources of income include employment as casual labourers, sale of farm produce, involvement in petty business and participation in women's self-help groups. In addition, the women's labour is required for food production, rearing and caring of children, the sick and the aged. The policy discourse does not highlight how women's labour subsidizes men and capital both of which enable men's participation in a cash economy, particularly in the formal employment sector. It does not indicate that the women's unpaid labour is the backbone of economic development. Rural women provide the physical and material labour to build schools and provide the resources their children require to acquire education for participation in the economy. However, even one of the most gender-sensitive reports, the Ndegwa report (1991), offers little opportunity for 
women's unpaid labour in the private sphere to be equally matched with services by the state to improve women's living conditions. The Ndegwa report claimed that "women's contribution to development has been widely acknowledged in official policy statements and development literature" (p. 229). Women's contribution to economic development deserve more than acknowledgment. The mere disclosure of women's contribution to development does not address the subordination and domination that women experience as well as the impoverished living conditions of most of the rural women. Meaningful acknowledgment should be matched with relevant policies to minimize women's exploitation and to ease their daily struggle in their attempts to create possibilities for their children.

The Ndegwa report (1991) further claims that the government has directed significant efforts at measures for promoting women's development and re-dressing the disadvantages suffered by women during the colonial period especially due to the neglect of their education. Although participation of girls in the primary level has reached parity to that of boys, statistics show that the drop out rate of girls in this level is about $60 \%$. Girls are still faced with a multitude of barriers in their attempt to access educational opportunities. The government's implementation of the cost-sharing strategy has worsened the situation by increasing parents' contributions to their children's education. One participant observed that the implementation of the cost-sharing strategy has certainly reduced the number of girls, particularly those from poor families in the rural areas, in achieving meaningful educational opportunities. The women's self-sacrificial income 
generating activities are limited. Most of the women cannot provide their girls meaningful educational opportunities.

The Ndegwa report (1991) called on Kenya to implement the Convention of all Forms of Discrimination against Women to which it is a signatory. It also called for an increase in the number of opportunities for women in key positions in private and public sectors of the formal employment sectors. ${ }^{1}$ Who benefits from such policies if they are implemented? Such policies benefit a small number of women and excludes the overwhelming majority of rural women and ordinary women workers.

Staudt (1987) argues that, while women share commonalities from their reproductive capacities, there are obvious differences among women based on their class position and resulting differences in opportunities and lifestyles. Staudt argues that women have not been universally disadvantaged. She points out that:

Given the near universal advantages of those with more education, money, land and in politics, women with those resources are politically advantaged and can acquire skills appropriate in given regimes along with a sense of "winnable" political goals. . . . Their winnability narrows the political agenda to demands compatible with the conception of women that the regime can accommodate. Very rarely do women activists in conventional politics articulate genuinely redistributive issues. . . . Should the wealthier women take up this redistributive issue in Kenya's zero-sum politics, more for other women would mean less for themselves. Their economic stakes lie more in their households than in solidarity with other women. (p. 203)

The Ndegwa report was produced with the input of two high-ranked women academics.

One had been the chairperson of the Maendeleo Ya Wanawake Organization (Progress for Women movement). It is not possible to know whether these women attempted to put through policies that would make rural women's lives less of a sacrifice but were

\footnotetext{
${ }^{1}$ The formal sector in Kenya is made up of the public and the private sectors.
} 
overruled by a predominantly male commission. What is clear is that the policy recommendation outcomes did little to lessen the burdens that rural women endure in their attempt to meet the basic needs of their families. The commissioners did not recommend redistributive policies that would give women in the rural communities access to resources such as land, credit and water to ensure food security and income from sale of cash crops and excess farm produce. More importantly, the Report did not challenge the structures that have made such conditions possible. In addition, the Report did not challenge the gender-biased ownership policies and laws stipulated in the Sessional Paper \#10 of 1965 which denied women ownership and control of property, particularly land. The right to own land and therefore acquire credit was systematically passed on to men who were assumed to be heads of households. The issuance of land title deeds to men as heads of households gave men absolute control over the land, its products and its disposal even against the will of the wife.

In addition, the Ndegwa report, which these two high ranking female academics helped produce, proposed support for women in home-based activities such as tailoring and food processing rather than policies to improve small-scale farming which would affect the lives of the $80 \%$ of the women living in the rural areas. Besides such policies reinforcing the public-private distinctions, they also benefit the local elite since the ensuing sewing programs are likely to be both irrelevant and time consuming for the majority of women who are engaged in a multiplicity of activities as food producers, petty traders and care givers (Staudt, 1987). 
Throughout the 30 years, most policy makers have formulated policies without considering their impact on women. For instance, unemployment became a social, economic and political concern when an overwhelmingly number of men began to crowd the urban areas in search of unavailable employment. The Mackay, Wanjigi and Kamunge Reports (1981, 1982 \& 1988) recommended and emphasized a rural-development focus to curb the rural-urban migration. Also recommended was a continual vocationalization of school subjects in order for school graduates to become self-employed. None of these reports examined (or recommended examination of) the impact of these policies on women if men remained in the rural areas particularly in connection with access to resources such as land. From this study it became clear that women utilize the limited land accessible to them to plant food crops and other crops for sale. Also, it became clear that women do not benefit from growing cash crops although their labor produces these cash crops--an exploitation that some women have resisted in subtle ways as in relegating their energies in planting food crops. It is clear that with more men having to depend on land for income, women's access to land will be adversely limited. This will also affect food security as men are likely to engage in cash crop production. This would ultimately impact female education as men would demand women's labour for cash crop production. They would also have direct access to the incomes and would not likely spend it on their families welfare, particularly on their daughters' education.

Vocationalization of school subjects for self-employment was seen by policy makers as a panacea for the looming high unemployment rates. The Reports recommended the introduction of courses such as masonry, carpentry and tailoring. In 
order for a school graduate to become self-employed they will have to purchase the equipment. In addition to the credit limitations, the courses provided are likely to attract boys since they are traditionally male fields.

Despite the policy recommendations on self-employment and provision of vocational subjects, women in this study seem to believe strongly that economic independence can only become possible through paid employment particularly in the formal employment sector. The women are not aware of the high unemployment rates and the discrimination that their daughters might face in the labour market. What is important to them right now is to provide their daughters with educational opportunities that gives them a chance to "knock on the doors" of the modern employment sector. The women's agency is not just around motherhood but they participate in economic roles that go a long way to make their children's and spouses'/partners' economic activities in the public possible.

However the women's agency is limited by policies that do increase their burdens such as the implementation of the cost-sharing strategy as a measure of structural adjustment programs. With this policy, the government has reduced spending on education and health services. The amount of fees that children have to pay at the secondary level is astronomical (at least $15,000 /=$ per year). In addition to school fees, parents are expected to buy stationery, uniforms and pay for other fees that might be deemed necessary. Mothers have stepped in as agricultural subsistence producers, petty traders, and workers to meet their children's educational needs. The women's economic activities are limited by the sexual division of labour assigning to them the responsibility of 
bearing and caring of children, sick and aged to women and the labour required for agricultural subsistence as well as cash crop production. In addition, women have limited access to resources. The intensification of their workload has threatened their health and their ability to provide for their children. Structural adjustment policies have a negative impact on the education of girls and the demand to invest heavily in the education of girls has made more parents invoke gendered cultural beliefs to make choices on who is to be educated. Girls' educational opportunities are limited by the preference for boys in the provision of educational opportunities based on the gendered cultural assumptions of inherent motherhood and high pregnancy rates among senior primary and secondary level girls. These are barriers that the policy makers do not address adequately.

\section{Implications for Policy}

An examination of the public policy discourse and the private discourse of the women in relation to education shows that policy makers continue to formulate policies that limit women's agency to the private sphere of a gendered society. The policy makers seem to uphold the image of a society with distinctive public and private spheres divided along gender lines. The perception of women held by policy makers limit women's educational opportunities as they confine women to the private sphere, oblivious of the activities that women are undertaking to provide their children with educational opportunities. The women's perception of themselves and their daughters is different from that held by the policy makers. The women do not see their daughters' agency defined around motherhood only but as economic and political agents in the public sphere alongside men. The women identify lack of resources and gender-related barriers that 
limit girls' education. The women, also identify the patriarchal ideology that limit their agency as intervention agents. These are factors that the policy makers did not address. There is need for the following changes to be effected to address factors that limit girls' education. There is need to (a) make gender and class equity issues pivotal in the policy making process, (b) provide material and psychological support for girls' education starting at the village level, (c) provide opportunity for re-entry of adolescent mothers into the school system and hold fathers of these children responsible for them, (d) introduce sex education in schools/communities, and (e) support women as intervention agents for their daughters' education as individuals and groups.

The examination of the policy documents in this study has shown that policy makers marginalize gender issues in the formulation of policies. This observation has also been made by Kivutha Kibwana, a law professor in the University of Nairobi who points out that official documents hardly concede to the issue of gender equity or sensitivity to women's issues. He notes that even in one of the most recent Development Plans (19891993), "women's role in Kenya society is fleetingly recognized" (1992, p. 9). Planning and the development of policies and programmes in Kenya have taken on the male perspective since men have dominated the public sphere of policy making and implementation. The policy makers see the world from the perspective of men rather than from the perspective of both men and women. This perception has reinforced gender inequities. In addition, policies that have been formulated and implemented that do not address the peculiar circumstances of both men and women. "Instead, they have in most cases ended up favouring men" (Kibwana, 1992). 
There is need for policy makers to address gender equity issues in the formulation of educational policies in a gendered society. In addition, there is need for women to be equally represented in the commissions and work parties charged with policy formulation. Maria Nzomo (1989) argues that it is only if women are well represented in policy making bodies that they can influence policy changes necessary for their empowerment.

Resistance to gender and women's issues is so pervasive in the society that even politicians will make overtly sexists remarks and threats and expect no criticism from other politicians or the head of their political party. ${ }^{2}$ There is hostility vented out to women who challenge the state for formulating gender-insensitive policies. Often these women are discredited by politicians and have been accused of being misled by Western feminist ideology. Stamp (1991) posits that:

The language of Western feminism is easily dismissed as yet another imperialist tool in the oppression of Third World people and a cause espoused by alienated and selfish elite African women. In this discourse, anti-imperialist ideology is articulated with right-wing and sexist political positions in a way that mystifies and discredits feminism and that stymies direct action in the name of women's rights. (p. 827)

Such women include professor Wangari Mathai, the first female professor of veterinary medicine, and founder of the world renowned environmental GreenBelt movement. She has consistently been described as a villain for challenging men's supremacy in the making of decisions that are gender biased and that also affect the environment. Women's agency continues to be perceived as emanating from their roles as mothers not as economic and political agents as men in the public sphere. Wangari (1991) observes that in Kenya "the

\footnotetext{
${ }^{2} \mathrm{~A}$ recent case in mind is the threat uttered by a Mr. Chepkok, a member of parliament to Wangari Mathai-Founder of the GmenBelt Movement in Kenya, in which be threatened that if she visited his constituency against his wish, she would be circumcised Kalenjin style--the ethnic group to which Chepkok belongs.
} 
sky is not the limit" for women, rather, gender, marriage and culture are women's limits. The education system that is supposed to help inculcate attitudes on the equality and rights of all persons in Kenyan youth is not doing so. For instance, women who comprise $80 \%$ of the small scale farmers are not represented as such in agriculture textbooks used in schools. Most girls are not choosing science and mathematics in high school (Eshiwani, 1990). Consequently, girls cannot pursue high status careers in science and technology. Orientation of the education of girls/women is for low-status jobs or for the provision of unpaid labour, which only reinforces the subordination of women.

Within the official circles and in society at large, the level of gender sensitivity is exceedingly low. There is resistance, mostly by men, to the genderization of issues because it challenges their expectations and male hegemony. It challenges patriarchy in which men assume superiority over women (Kibwana, 1992). Women, as the majority of voters, must seek to elect women who are sensitive to gender issues to parliament in large numbers because it is in the parliament where the laws that influence women's lives are passed. Making gender a category of policy analysis means challenging deeply engrained gendered assumptions that reinforce gender inequities not only in education but in the general society.

In addition to employing gender as a category of analysis, the class issue must also be taken into consideration. As Mohanty (1991) points out, women are not a monolith. The impact of policies on middle class urban women who are advantaged by education, money, and political power cannot be the same as those of the poor rural women who have no access to land, shelter and money. Staudt (1987) argues that women with these 
advantages do acquire favours in given regimes. Women's daily experiences are also shaped by factors such as ethnicity and the region where they live. For instance, the International Labour Organization studies on employment opportunities for rural women gave the impression that most rural women can find work in plantations or in large scale farms. This might be a reality for a few women who live in the $17 \%$ arable region of Kenya. Therefore, the impact of policies in relation to class must be examined, even though in the Sessional Paper \# 10 (1965) Kenyan politicians and policy makers denied the existence of classism in the society. Addressing gender and class issues in policy making is a great challenge to the status quo.

\section{Support For Girls' Education Starting At The Village Level}

This study has shown that the high school fees charged at the secondary levels are a great barrier to girls' educational opportunities. Some girls who have been admitted to government-maintained schools, which are well established and have facilities, equipment, qualified teachers and extra-curricula educational opportunities, have had to go to inferior quality harambee day schools which are relatively cheaper. Most harambee schools do not have qualified teachers and do not teach pure science subjects. Students' performance in the university entry examinations are poor in harambee schools. It is therefore important to ensure that girls who are admitted to government secondary schools make it into these schools. This can be facilitated through the establishment of a special fund for such cases. Information on how to access these funds should be made available to parents at the village level. At present, there is supposed to be a fund that helps needy children. During my fieldwork, I found that most rural women do not know of its existence, and those who 
know about it and have applied for funds were frustrated and intimidated by the lengthy time and money-consuming and corrupt process, so they eventually gave up.

In addition, if a girl does not report to secondary school after she has been admitted, it would be important for the head teacher to be aware of the circumstances surrounding this case. Often, girls will not show up at school because of lack of school fees, uniforms, even bus fare or early marriage. Head teachers are swift to give away vacancies that become available in this manner. It is important that the head teacher contact the parents/guardians through the divisional education office before the girl's place is given to somebody else. It could be that this girl's father has refused to invest in her education because he wants to wed her off or to go and work as a house girl. There should be options available to ensure that such a girl goes to school.

\section{Re-entry of Adolescent Mothers into the School System}

The number of adolescent mothers is on the increase (UNICEF/Government of Kenya, 1992). Women who participated in this study pointed out that many girls are leaving school because of pregnancy and this marks the end of formal schooling. Schools do not re-admit a girl who leaves school due to pregnancy because she is considered a bad role model. In addition to this, a girl who leaves school because of pregnancy is a big disappointment to her parents, and most fathers, who pay school fees most of the time and allocate resources in the household, consider it "risky" to reinvest in the education of such a girl. Therefore, it becomes almost impossible for this girl to re-enter the formal education system. Consequently, the girl's educational and economic opportunities are limited and she often ends up in a subordinated role in a marriage relationship. It is 
important that such girls are given a chance to continue with formal schooling without being discriminated against. It is also important that girls are given the space to talk about the circumstances that led to the pregnancies. Most of the time, there is an adult male involved, often a teacher, who admonishes the girl to remain silent. These men who abuse their power are often never brought to justice. Girls need to be provided with the channels and necessary skills to deal with such men. They need to be able to report sexual harassment and abuse without fear of being accused of provoking it. There is need to deal with the double standard of victimizing girls who get pregnant while letting the men responsible for the pregnancies continue with their education or careers undisturbed. The issue of sexual harassment has to be addressed and procedures be put in place to deal with sex offenders at all levels of the society. Tough laws need to be put in place for those adults who are responsible. At the moment, it is the responsibility of a rape victim to prove that she did not provoke it. This treatment has only served to silence the majority of rape victims.

Parents need to be made aware of ways to support their daughters who give birth while in schools other than consider them as outcasts. The stigma and psychological stress associated with teenage pregnancy has caused many teenage deaths as they attempt to procure illegal abortions.

Addressing the issue of teenage pregnancy and the treatment of teenage mothers requires challenging patriarchy and its control of women's sexuality. Hartman (1993) argues that patriarchy, a set of interrelations among men that allow men to dominate women, has a material base. The material base is men's control over women's labor 
power, and "that control is maintained by excluding women from access to necessary economically productive resources and by restricting women's sexuality" (p. 196).

\section{Introducing Sex Education in Schools and Communities}

Introduction of Western formal education and Christianity replaced traditional education in which grandmothers played crucial roles as sex educators. Since grandmothers lost their role and credibility as knowledgeable sex educators, they have not been replaced. Recent attempts to introduce sex education in schools have been impeded by religious groups and parents who felt that their children will be taught to be promiscuous. There is need for a consensus on how this issue should be approached because teenage girls are getting pregnant and leaving school, and even worse they are dying. Local newspapers are filled with stories like "a 17 year-old high school student who was pregnant was murdered by her boyfriend as he tried to procure an abortion" (The Standard, January 16, 1995). Most cases go unreported. Students, both boys and girls, need to be aware of their sexuality and responsibilities that go with it. There is need for girls to be made aware that they should not tolerate sexual harassment or abuse. I would recommend that there be an adult who girls can trust to discuss sex related matters without being made to feel "immoral". Grandmothers represented that individual whom girls could trust in the past. Schools can use individuals from the community, ranging from contemporary sex educators to traditional sex educators--grandmothers. 


\section{Support for Women as Intervention Agents for their Daughters' Education}

This study showed how mothers are involved in a multiplicity of activities in an effort to improve their families' living conditions and to provide their children with educational opportunities. The women's endeavours are impeded by the rising costs of living and the implementation of structural adjustment policies that have meant less government funding on education and health services. Their efforts are also limited by the traditional sexual division of labour and limited access to resources. The activities that the women are engaged in are labour-intensive and brings them minimum profits that can barely meet their families' basic needs, not to mention educational needs. The rotating credit that the women's self-help groups operate provides its members with only temporary help because it comes once in a long time when the woman has already accumulated huge debts and expenses such as school fees and doctors' fees, that cannot be offset with a one-time credit.

The Kenya government, international donor countries, and development agencies have come to look upon women's self-help groups as the most viable organizational base for implementing women's projects ranging from social welfare to those dealing with income generation. Consequently, a lot of money has been made available to the government to channel to the women's projects. Unfortunately, this money does not seem to get to most women because of the politics of aid in the national and local levels. Nzomo (1989) argues that economic programs being promoted under the umbrella of women's groups have not enabled women to attain economic empowerment. In addition, the women's groups excludes over $60 \%$ of eligible women in Kenya. 
There are, however, various benefits that women get from participating in women's groups. For example, women benefit from the social interaction group membership gives since the women get a chance to break from their individual isolation and confinement in their respective homes and family-related activities. It is, however, important that these self-help groups be made more inclusive and independent from local and national government control. A few women's self-help groups in semi-arid areas have received credit and organizational skills from organizations such as the African Medical Research Foundation (AMREF) that have increased the groups' income tremendously.

There is need to focus on individual women and to find out how individual women may be supported to support themselves. Most of the women who participated in this study noted lack of credit a major barrier to their individual businesses. These women need to have access to credit. One method that has been adopted by a non-governmental organization working in Kibwezi (an opposition zone) is to provide credit to a women's self-help group for individual women. The group is the collateral and the individual woman owes it to the entire group to repay back the loan. This method is the underlying principle behind the successful Grameen Bank in Bangladesh which is run and owned by poor rural women. The Grameen Bank was started by economist Mohammed Yunus (Yunus, 1991).

The women also identified food shortages due to poor rainfalls as one of the major problems they face and one which consumes much of the income they earn from their many ventures. They also noted that availability of water would be a major solution to the problem of food. A borehole would be of great help to these women. 


\section{Significance of the Study}

The objective of this research was ambitious when one considers the complexity of women's education and the factors that shape it since women's education does not take place in a vacuum. I explored women's experiences of education from which I construed what I call "women's private discourse of education." I contrasted the women's discourse with the public discourse of education articulated in policy documents. Beyond the rural women's experiences of education, I examined the women's agency in their multiple subjectivity as mothers, sisters, daughters, workers, educators and traders to understand how they perceive themselves and explain their actions. The women's self-perception counters the facile but popular imagery that reduces the African woman to an anguished, helpless mother holding a famished child (Stamp, 1995).

This study, therefore, contributes to the limited studies on African women as social agents. It is a ground-breaking study that shows how rural women in Kilome are responding to the social, economic and political changes and how they are creating educational and economic possibilities for their children. The study highlights the women's experiences of education and the limitations that they faced as well as those that their daughters face. The study shows how women's agency is limited by policies.

The study has attempted to analyze the voices of the women of Kilome about their experiences and about factors that limited their educational opportunities and how their participation in the society has been structured. It has sought to show the women's visions, struggle and courage to provide for their children's needs. It has also sought to show women's compliance with formal discourses. The power of the methodology is that 
it provided space for the women's conditions to become visible from their standpoints. The methodology did not objectify the women, rather, the women's agency became perceivable in the changing cultural, historical, economic and political environment of Kenya society.

I recommend further research to examine the impact of the high cost of schooling on girls' education. The interplay between the high cost of schooling and the gendered cultural assumptions that limit girls' education is crucial. There is also need for further research to examine the problem of adolescent motherhood and recommend ways to help these girls to achieve their educational goals. These are issues that women noted as having negative impact on the education of girls. At present, the government has appointed a task force to examine the laws of Kenya with an aim of recommending gender-sensitive laws. I recommend adoption of a similar methodological approach which identifies women as agents and begins the inquiry from their standpoints. This would provide additional information to policy makers, educators and parents, continuing the search for ways to redress the observed gender inequities in accessing educational and economic opportunities. This approach makes change more open to human agency and to women's feminist political action. 


\section{References}

Ahlberg-Maina, Beth (1991). Women, Sexuality and the changing social order: The impact of Government policies on Reproductive behaviour in Kenya. Philadelphia, PA: Gordon and Breach.

Alcoff, Linda (Winter 1991/92). The problem of speaking for others. Cultural critique, $23,5-31$.

Anderson, K \& Jack, D. C. (1991). Learning to listen: Interview techniques and analyses. In S. B. Guck \& D. Patai (Eds.), Women's Words: The feminist practice of oral history. New York, NY: Routledge.

Apple, M. (1991). Series Editor's Introduction. In P. Lather (1991), Getting smart feminist research and pedagogy with/in the postmodern (pp. vii-xi). New York, NY: Routledge.

Bell, D., Caplan, P \& Karim, W. H. (Eds.) (1993). Gendered fields: women, men and ethnography. New York, NY: Routledge.

Bellew, R. T \& King, E. (1993). Educating women: Lessons from Experience. In, E. King and M. A. Hills (Eds.), Women's Education in Developing Countries: Barrier, Benefits and Policies.

Biraimah, K. (1991). Access, equity, and course outcomes: Women students' participation in Nigerian higher education. In G. P Kelly \& S. Slaughter (Eds.), Women's higher education in comparative perspective (pp. 219-231). Netherlands: Kluwer Academic Publishers.

Boserup, E. (1970). Women's role in economic development. London: George Allen and Unwin Ltd.

Brett, E. A (1983). The world's view of the IMF. In The Poverty Brokers: The IMF and Latin America. London: Latin America Bureau.

Children and women in Kenya: A situation analysis (1992). A publication of the Government of Kenya and the UNICEF Kenya Country office: Nairobi: Reata Printers Limited.

Chlebowska, K. (1990). Literacy for rural women in the third world. Paris: UNESCO.

Cubbins, L. A. (991). Women, Men, and the division of power: A study of gender stratification in Kenya. Social Forces, 69(4), 1063-1083. 
Dale, R. (1989). The state and education policy. Toronto: OISE Press.

Davies, B. C. (1986). Introduction: feminist consciousness and African literary criticism. In, C. B Davies \& A. A. Graves (Eds.), Ngambika studies of women in African literature (pp. 1-24). Trenton, NJ: African World Press.

Dei, G. J. S. (1995). Indigenous Knowledge and social development: Making connections. Invitational Address read at the International Development Organizations Conference. York University, Ontario, February 3-5, 1995.

Downey, L. W. (1988). Policy analysis in education. Calgary, AB: Detselig Enterprises.

Due, J. (1991). Policies to overcome the negative effects of structural adjustment programs on African female-headed households. In C. H. Gladwin (Ed.), Structural adjustment and African women farmers. Gainesville, FL: University of Florida Press.

Eicler, M. (1983). Sexism in Research and its policy implications. Ottawa, ONT: CRIAW.

Eshiwani, G. S. (1983). A study of women's access to higher education in Kenya with special reference to mathematics and science education. Unpublished report. Nairobi: Bureau of Educational Research.

Eshiwani, G. S. (1985). The Education of Women in Kenya, 1975-1984. (ERIC Document Reproduction Service No. ED 284 802).

Eyre, L. (1993). The social construction of gender in the practical arts. Unpublished doctoral dissertation, University of British Columbia, Vancouver.

Fals-Borda, O \& Rahman, A. M. (Eds.). (1991). Action and Knowledge: Breaking the monopoly with Participatory Action-Research. New York, NY: The Apex Press.

Feldman, Rayah (1983). Women's groups subordination: An analysis of policies towards rural women in Kenya. Review of African Political Economy, 27/28, 67-85.

Freeman, C. (1988). Colonialism and the formation of gender hierarchies in Kenya. Critique of Anthropology, 7(3), 33-50.

Freire, P. (1985). The politics of education: culture, power and liberation. Massachusetts: Bergin and Garvey.

Freire, P. (1990). Pedagogy of the oppressed 3rd Edition. New York, NY: The Continuum Publishing Company. 
Gluck, S. B. \& Patai, D. (Eds.). (1991). Women's words: The feminist practice of oral history. New York, NY: Routledge.

Hakansson, T. (1988). Bridewealth, women and land: social change among the Gusii of Kenya. Stockholm: Graphic Systems.

Hammersley, M. \& Atkinson, P. (1983). Ethnography principles and practice. New York, NY: Tavistock Publications.

Harding, S. (Ed.). (1986). Feminism and methodology: Social science issues.

Bloomington, IN: Indiana University Press.

Hartmann, H, I. (1993). The unhappy marriage of marxism and feminism: Towards a more progressive union. In A. M. Jaggar \& P. S Rothenberg (Eds.), Feminist frameworks. Alternative theoretical accounts of the relations between men and women (3rd ed.) (pp. 191-202). New York, NY: McGraw-Hill.

Hill, M, J. (1991). The harambee movement in Kenya: self-help, development, and education among the Kamba of Kitui district. Atlantic Highlands, NJ: Athlone Press.

Hughes, R., \& Mwiria, K. (1989). Kenyan women, higher education and the labour market. Comparative Education, 25(2), 179-195.

Hyde, K. (1993). Sub-Saharan Africa. In E. M. King \& M. A. Hill (Eds.), Women's Education in developing countries: Barriers, benefits and policies. Baltimore: The John Hopkins University Press.

International Labour Organization (ILO) (1991). Exploratory mission on women's employment. ILO, Geneva.

Jaggar, A. (1983). Feminist politics and human nature. Totowa, NJ: Rowman \& Littlefield Publishers.

Jobs and Skills programme for Africa (JASPA) (1981). Employment problems of rural women in Kenya. International Labour Office, Addis Ababa.

Jobs and Skills Programme for Africa (JASPA) (1986). Women's Employment patterns, discrimination and promotion of equality in Kenya. International Labour Office. Addis Ababa.

Johnson, H \& Berstein, H. (1984). Third World lives of struggle. London: Heinmann Educational books. 
Kagia, R (1985). The effect of Education on Employment Opportunities for women in Kenya. In, N. Olembo; E. Gachukia \& N. Waita (Eds.), Kenyan women in Development: Research Papers for Forum 1985. Nairobi.

Kamunge Report (1988). Republic of Kenya. Report on the Presidential Working Party on education and manpower training for the next decade and beyond. Nairobi: Government Printers.

Kardam, Nuket (1991). Bringing women in: women's issues in international development programs. London: Lynne Rienner Publishers.

Kibwana, K. (1992). Gender and Development: Why Gender is a development issue. A discussion paper prepared for CREUMHS' Gender awareness workshop for Kwale water project personnel. Mombasa.

Kiiti, N. (1993, December). Swimming against the current: maintaining a balance between building a successful career and making home is a stressful exercise. Lady, pp. 1718.

Kurian, G. T. (1987). World education encyclopedia. New York, NY: Facts on file.

Lather, P (1991). Feminist research in education: within/against. Victoria: Deakin University.

Lather, P. (1986). Issues of validity in Openly Ideological Research: Between a Rock and a Soft Place. Interchange, 17(4), 63-84.

Llewelyn-Davies, M. (1981). Women, warriors, and patriarchs. In, S. B. Ortner \& H. Whitehead (Eds.), Sexual meanings: The construction of gender and sexuality (pp. 330-358). London: Cambridge University Press.

Mbilinyi, M. (1972). The "New Woman" and Traditional norms in Tanzania. Journal of Modern African Studies, 10(1), 57-72.

McAdoo, P. H. \& Were, M. (1987). Extended family involvement and roles of urban Kenyan women. In R. Terborg-Penn, S. Harley \& A. Rushing, (Eds.), Women in Africa and African Diaspora. Washington, DC: Howard University Press.

MacKay Report (1981). Second university in Kenya. Republic of Kenya. Nairobi: Government Printers.

Mann, S. P. (1995). Cyborgean motherhood and abortion. In J. K. Gardiner, (Ed.), Provoking agents: Gender and agency in theory and practice (pp. 133-151). Chicago, IL: University of Illinois Press. 
Mbiti, J. S. (1990). African religions and philosophy. (2nd ed.). Portsmouth, NH: Heinemann.

Mies, M. (1983). Towards a methodology for feminist research. In G. Bowles \& R. Klein (Eds.). Theories of Women's Studies. London: Routledge \& Kegan Paul.

Mohanty, C. (1991). Under Western eyes. Feminist scholarship and colonial discourses. In, C. Mohanty, A. Russo \& L. Torres, (Eds.), Third World women and the politics of feminism (pp. 51-80). Indianapolis: Indiana University Press.

Mukui, J. T.(1985). The impact of social factors on the employment situation of women in Kenya. In N. Olembo; E. Gachukia \& N. Waita (Eds.), Kenyan women in Development: Research Papers for Forum 1985. Nairobi

Munachonga, M. (1988). Income allocation and marriage options in urban Zambia. In D.Dwyer \& J. Bruce (Eds.), A home divided: women and income in the Third World (pp. 173-194). Stanford, CA: Stanford University Press.

Muthiani, J. (1973). Akamba from within: Egalitarianism in social relations. New York, NY: Exposition Press.

Ndegwa Report (1991). Republic of Kenya. Development and employment in Kenya: A strategy for the transformation of the economy. Nairobi: Government Printers.

Ndunda, M., \& Munby, H. (1991). "Because I am a Woman": A study of culture, school and futures in science. Science Education, 75(6), 683-699.

Nzomo, M. (1989). The impact of the Women's Decade on policies, programs and empowerment of women in Kenya. Issue, 17(2), 8-16.

Obbo, C. (1980). African women: Their struggle for economic independence. London: Zed Press.

Obura, A. (1992). Changing Images: portrayal of girls and women in Kenyan textbooks. Nairobi: ACTS Press.

Ominde, H. (1964). Kenya Education Commission Report. Nairobi: Government Printers.

Ondiege, P. O (1992). Local coping strategies in Machakos district, Kenya. In F. D. Taylor \& F. Mackenzie, F. (Eds.), Development from Within: Survival in rural Africa. New York, NY: Routledge.

Ortner, S. (1981). Accounting for sexual meanings. In S. Ortner \& Whitehead, (Eds.), Sexual meanings: The cultural construction of gender and sexuality. Cambridge: Cambridge University Press. 
Osler, A. (1993). Education for development and democracy in Kenya: a case study. Educational Review, 45(2), 165-173.

Potash, B. (1989). Gender relations in Sub-Saharan Africa. Gender and Anthropology Critical reviews for research and teaching. Washington, DC: American Anthropological Association.

Rathgeber, E. (1991). Women in higher education in Africa: access and choices. In G. P Kelly \& S. Slaughter (Eds.), Women's higher education in comparative perspective, (pp. 47-62). Netherlands: Kluwer Academic Publishers.

Reinharz, S. (1992). Feminist methods in social research. Toronto: ONT: Oxford University Press.

Republic of Kenya. 1974-78 Development Plan. Nairobi: Government Printers.

Republic of Kenya. Laws of Kenya: Education Act (1980). Nairobi: Government Printers.

Republic of Kenya. 1989-93 Development Plan. Nairobi: Government Printers.

Republic of Kenya. Statistical Abstracts (1991). Central Bureau of Statistics, Ministry of Planning and National development. Nairobi : Government Printers.

Republic of Kenya. Development and Employment Report, 1991. Nairobi: Government Printers.

Republic of Kenya. Economic Survey, 1990. Ministry of Planning and National Development. Nairobi: Central Bureau of Statistics.

Republic of Kenya. Economic Survey, 1991. Ministry of Planning and National Development. Nairobi: Central Bureau of Statistics.

Republic of Kenya: Kanu Manifesto Sessional Paper \# 10 (1965). Nairobi: Government Printers.

Republic of Kenya: Ministry of Labour (1968). Helping you choose a career. Kenyanization of Personnel Bureau. Nairobi: Government Printers.

Republic of Kenya: Statistical Abstracts (1991). Nairobi: Government Printers.

Republic of Kenya: Employment and earnings in the formal and informal sector: A gender analysis. Women's Bureau/SIDA project, 1992. Ministry of Culture and Social Services. Nairobi: Government Printers. 
Riria-Ouko, J (1984). Education for all: The neglected Half. Basic Education Resource Centre. Nairobi, Kenya.

Robertson, C. \& Berger, I. (Eds.). (1986). Women and class in Africa. New York: Africana Publishing Company .

Salazar, C.(1991). A third world woman's text: Between the politics of criticism and cultural politics. In S. B. Gluck \& D. Patai (Eds.), Women's words: The feminist practice of oral history (pp. 93-106). New York, NY: Routledge.

Scheurich, J. (in press). The masks of validity and the Western knowledge project.

Scott, M. A. (1990). Patterns of patriarchy in the Peruvian working class. In S. Stichter \& J. L. Parpart (Eds.), Women, employment and the family in the international division of labour (pp. 198-220). Hampshire: Macmillan Press.

Sifuna, N. D. (1990). Development of education in Africa: the Kenyan experience. Nairobi: Initiatives.

Smith, D. E. (1987). Everyday world as problematic: A feminist sociology. Toronto: University of Toronto Press.

Stacey, J. (1991). Can there be a feminist ethnography? In S. B. Gluck \& D. Patai (Eds.), Women's Words: The feminist practice of oral history. New York, NY: Routledge.

Stackhouse, J. (1995, March 9). Why land is better than a job. Globe \& Mail.

Stamp, P. (1986). Kikuyu women's self-help groups. Toward an understanding of the relation between sex-gender system and mode of production in Africa. In Robertson, C. \& Berger, I. (Eds.), Women and class in Africa (pp. 27-47). New York: Africana Publishing Company.

Stamp, P. (1989). Technology, Gender, and Power in Africa. Ottawa, ONT: IDRC.

Stamp, P. (1991). Burying Otieno: The politics of gender and ethnicity. Signs, 16(4), 808-845.

Stamp, P. (1995). Mothers of invention: Women's agency in the Kenyan State. In L. Gardner (Ed.), Provoking agents, gender and agency in theory and practice (pp. 69-92). Chicago, IL: University of Illinois Press. 
Staudt, K. (1987). Women's politics, the state, and capitalist transformation in African. In I. L. Markovitz (Ed.), Studies in power and class in Africa (pp. 193-208). New York, NY: Oxford University Press.

Staudt, K \& Glickman, H. (1989). Beyond Nairobi: Women's politics and policies in Africa Revisited. Issue: Journal of Opinion 17(2), 4-7.

Staudt, K \& Parpart, J. (1989). Introduction to women and the state in Africa. In K. Staudt \& J. Parpart (Eds.), Women and the State in Africa (pp. 1-19). London: Lynne Rienner Publishers.

Stichter, S. \& Parpart, L. J. (1988). Patriarchy and class: African women in the home and the workforce. London: Westview Press.

Stromquist, N. P. (1987). Global perspectives on sexuality and equity in education. Peabody Journal of Education, 64(4), 25-43.

Stromquist, N. P. (1991). Feminist reflections on the Peruvian university politics. In G.P. Kelly \& S. Slaughter (Eds.), Wnmen's higher education in comparative perspective, (pp. 63-83). Netherlands: Kluwer Academic Publishers.

Thomas, B. (1985). Politics, participation and poverty. Development through self-help in Kenya London: Westview Press.

Thomas, R. M (Ed.).(1992). Education's role in national development plans: Ten country cases. New York, NY: Praeger.

Urdvardy, M. (1988). Women's Groups near the Kenyan coast: Patron-clientship in the development arena. In, D. W. Brokensha \& P. D. Little (Eds.), Anthropology of Development and change in East Africa, (pp. 217-237). London: Westview Press.

UNICEF (1992). Strategies to promote girls' education: policies and programmes that work. Education Section. New York, NY: UNICEF.

Van Maanen, J. (1988). Tales of the field. Chicago, IL: The University of Chicago Press.

Vickers, J. (1991). Women and the world economic crisis. New Jersey, NJ: Zed Press. 
Wanjigi Report (1982/83). Unemployment Report. Republic of Kenya Nairobi: Government Printers.

World Bank Country Study, Kenya (1989). The role of women in economic development. Washington, DC: World Bank.

Yunus, M. (1991, March 5). [Interview with David Cayley, Ideas writer CBC: The Grameen Bank]. CBC IDEAS Transcripts. 